Characterization of U(VI) Sorption-Desorption Processes and Model Upscaling

Final Report for the Period September 2002 to July 2006

Date Issued/Published: October 12, 2006

\author{
Jing Bai, Wenming Dong, Ph.D., and \\ William P. Ball, P.E., Ph.D., DEE \\ Department of Geography \& Environmental Engineering, \\ The Johns Hopkins University
}

\author{
Prepared for the \\ United States Department of Energy \\ Environmental Management Science Program
}

Award Number: EMSP 86748; Contract No. DE-FG07-02ER63498 
Other Partners: The project reported was conducted at Johns Hopkins University in close collaboration with Dr. Chongxuan Liu of the Pacific Northwest National Laboratory. This project was also part of a larger collaborative effort being undertaken with other investigators at the Pacific Northwest National Laboratory (Dr. John M. Zachara, Dr. Chongxuan Liu, and Dr. Zheming Wang), the Los Alamos National Laboratory (Dr. Peter Lichtner), and Stanford University (Dr. Gordon E. Brown) to undertake research as described in a March, 2002 proposal to the FY-02 Environmental Management Science Program, entitled "Characterization of U(VI) Sorption-Desorption Processes and Model Upscaling," under the direction of Dr. John M. Zachara, Principal Investigator. The project reported here had a narrower focus, and was specifically designed to better understand the coupled adsorption, diffusion, and transport of adsorbing U(VI) species in pristine subsurface materials from the Hanford site. The results from this project will ultimately be compared and integrated with those from other institutions to meet the objectives of the overall collaborative project.

Contact(s): PI: William P. Ball, JHU (bball@jhu.edu); administrative contact: Timothy Allgire (tallgire@jhu.edu; Tel: 443-997-8967) 


\section{Overview of Project and Organization of Report}

\section{Objectives and Hypotheses}

The objectives of the overall collaborative EMSP effort (with which this project is associated) were to characterize sorption and desorption processes of U(VI) on pristine and contaminated Hanford sediments over a range of sediment facies and materials properties and to relate such characterization both to fundamental molecular-scale understanding and field-scale models of geochemistry and mass transfer. The research was intended to provide new insights on the mechanisms of U(VI) retardation at Hanford, and to allow the development of approaches by which laboratory-developed geochemical models could be upscaled for defensible field-scale predictions of uranium transport in the environment.

Within this broader context, objectives of the JHU-based project were to test hypotheses regarding the coupled roles of adsorption and impermeable-zone diffusion in controlling the fate and transport of U(VI) species under conditions of comparatively short-term exposure. In particular, this work tested the following hypotheses: (1) the primary adsorption processes in the Hanford sediment over the $\mathrm{pH}$ range of 7 to 10 are surface complexation reactions of aqueous U(VI) hydroxycarbonate and carbonate complexes with amphoteric edge sites on detrital phyllosilicates in the silt/clay size fraction; (2) macroscopic adsorption intensity (at given aqueous conditions) is a function of mineral composition and aquatic chemistry; and (3) equilibrium sorption and desorption to apply in short-term, laboratory-spiked pristine sediments; and (4) interparticle diffusion can be fully understood in terms of a model that couples molecular diffusion of uranium species in the porewater with equilibrium sorption under the relevant aqueous conditions. The primary focus of the work was on developing and applying both models and experiments to test the applicability of "local equilibrium" assumptions in the modeling interpretation of sorption retarded interparticle diffusion, as relevant to processes of U(VI) diffusion in silt/clay layers. Batch isotherm experiments were first used to confirm sorption isotherms under the intended test conditions and diffusion cell experiments were then conducted to explore the diffusion hypotheses.

\section{Background:}

Uranium (VI) is a ubiquitous contaminant at Hanford and other DOE sites, resulting from its central role in the nuclear fuel cycle (Riley et al., 1992). Understanding $\mathrm{U}(\mathrm{VI})$ transport in the subsurface sediments at these sites is critical for risk assessment and remediation efforts. While large-scale $U$ migration in the subsurface is generally determined by advection along permeable pathways, local scale transport in less permeable regions, such as rock matrices or fine-grained (e.g. clayey) soils is controlled by diffusion (Arnold et al., 2003; Muurinen, 1990; Tokunaga et al., 2004).Underground migration of uranium (VI) at Hanford, WA, and other DOE sites is affected by sorption and desorption processes with numerous different mineral solids possessing a range of material properties(Barnett et al., 2002; Davis, 2001; Dong et al., 2005; Liu et al., 2004; McKinley et al., 1995). Hanford vadose zone pore water and groundwater is generally at equilibrium with calcite that exists as a minor mineralogical component of all subsurface sediments(Serne et al., 2002). Existence of calcium in the mineral assemblabe and in pore 
water of the sediments may influence the interaction of U(VI) with the sediments. Within this context, the purpose of this study is to experimentally test the proposed hypotheses regarding the sorption and desorption of U(VI) and the interplay of such sorption with the interparticle transport of U(VI) species in water.

\section{Brief Overview of Results}

Important new information was obtained about the role of aqueous calcium and solid calcium carbonate in controlling sorption equilibrium with Hanford sediments. The retarded interparticle diffusion model with local sorption equilibrium was shown to very successfully simulate diffusion at high aqueous concentration of U(VI). By contrast, however, diffusion data obtained at low concentration suggested nonequilibrium of sorption even at diffusion time scales. Such nonequilibrium effects at low concentration are likely to be the result of sorption retarded intraparticle diffusion, and strong U(VI) sorption in the low concentration range.

\section{Organization of This Report}

Part I. Solid Processing and Characterization

Part II. Study of the Influence of Calcite on Uranium(VI) Sorption (This study has been published: Environmental Science and Technology, 2005, 39(20): 7949-7955)

Part III. Study of Uranium(VI) Sorption/Desorption Dependence on Solid/Solution Ratio at $\mathrm{pH} 9.4$

Part IV. Experimental and Modeling Study of Retarded U(VI) Diffusion in Hanford Silt/Clay Material (This study was in preparation for publication) 


\section{Part I. Solid Processing and Characterization}

\section{Materials and Methods}

\subsection{Collection and Processing of Samples}

The Hanford materials studied were taken from a composite of clay/silt sediments (Hanford Silt Composite, HSC) that was prepared by Pacific Northwest National laboratory (PNNL) colleagues from core samples. HSC was collected over from the Pliopleistocene layer between the Hanford and Ringold formations at a borehole beneath the Hanford reservation in Area 200 (RCRA borehole \# 299-W22-48) (Serne et al., 2002), at selected depth intervals between 42 and 44 meters below ground surface. The HSC materials were sampled from a zone of sediment that is largely dominated by quartz ( $\sim 45 \%$ to $95 \%$ ), plagioclase feldspar ( $\sim 10 \%$ to $20 \%$ ), and alkali feldspar ( $20 \%$ to $40 \%)$ (Serne et al., 2002). Specific XRD analysis of the HSC sample conducted elsewhere (unpublished data obtained at PNNL) revealed that major mineral components of the HSC composite are: quartz $\left(\mathrm{SiO}_{2}\right)$, albite $\left(\mathrm{NaAlSi}_{3} \mathrm{O}_{8}\right)$, clinochlore $\left[(\mathrm{Mg}, \mathrm{Fe})_{6}(\mathrm{Si}, \mathrm{Al})_{4} \mathrm{O}_{10}(\mathrm{OH})_{8}\right]$, potassicpargasite $\left[\mathrm{KCa}_{2}\left(\mathrm{Mg}_{3} \mathrm{FeAl}\right)\left(\mathrm{Si}_{6} \mathrm{Al}_{2}\right) \mathrm{O}_{22}(\mathrm{OH})_{2}\right]$, and muscovite $\left[\mathrm{KAl}_{2}\left(\mathrm{Si}_{3} \mathrm{Al}\right) \mathrm{O}_{10}(\mathrm{OH}, \mathrm{F})_{2}\right]$. Calcite $\left(\mathrm{CaCO}_{3(\mathrm{~S})}\right)$ was also detected by the XRD as a minor component.

The original HSC sample sent to JHU was dry on receipt. This sample was carefully split into two portions with a two-way splitter. One portion of the original HSC sample was stored dry and in the dark at laboratory temperature. The other portion was sieved into size fractions of 2000 to $53 \mu \mathrm{m}$ (sand fraction) and $<53 \mu \mathrm{m}$ (silt/clay fraction) with a wet sieve method: the HSC sample was suspended in deionized water and then thoroughly sieved with a $53 \mu \mathrm{m}$ size sieve. The silt/clay size fraction $(<53 \mu \mathrm{m})$ and sand size fraction $(>53 \mu \mathrm{m})$ were collected and air-dried at laboratory temperature. Our wet sieve analysis of this material has revealed that roughly $31 \%$ of this material is in the sand size fraction $(>53 \mu \mathrm{m}), 61 \%$ in the silt fraction $(2-53 \mu \mathrm{m})$ and $6 \%$ in the clay fraction $(<2 \mu \mathrm{m})$.

In addition, we used calcite as an additional sorbent to investigate its contribution to U(VI) sorption. The calcite was in the rhombic cleavage form and was obtained from Sargent-Welch Scientific. It was ground to a fine powder $(<200 \mu \mathrm{m})$ using a ball mill.

\subsection{Preparation of Carbonate-Free and Iron Minerals-Free HSC Samples}

A portion of the silt/clay size-fraction was treated with a 1 mole/L sodium acetate (NaOAc) solution at $\mathrm{pH} 5.0$ (adjusted with acetic acid) to remove carbonate minerals. The treatment procedure used was that described by (Zachara et al., 2002), with minor modification as described in Protocol A of Appendix II. The remaining materials after treatment (hereafter referred to as "carbonate-free silt/clay) were air-dried, homogenized, and split into two fractions, one of which was used directly for U(VI) adsorption experiments and one of which was further treated to remove iron (hydr)oxides. The carbonate removal procedure ensured that calcite in the sediment materials was removed, and that the portion of calcium sorbed to mineral surfaces was also removed by ion exchange with sodium. 
The original HSC, the HSC silt/clay fraction and the carbonate-free silt/clay materials were equilibrated by Milli-Q water at a solid/solution of $100 \mathrm{~g} / \mathrm{L}$. The cation species in the solution phase were measured by ICP-OES at PNNL. The anion species were measured by Ion Chromatography (DX-120, Dionex Corp., Sunnyville, CA)

Iron (hydr)oxide-extracted sediment was prepared by chemical treatment of the carbonate-free silt/clay with a dithionite-citrate-bicarbonate (DCB) solution following a method described by Mehra and Jackson (1960). Details of the DCB extraction can be found in Protocol A in Appendix II.

\subsection{Solid Characterization}

Surface Area. The surface area of the sediments was measured by the traditional BET method on a BET surface analyzer (ASAP 2000, Micromeritics, Norcross, GA).

Carbonate Content. The HSC materials contained some carbonates, including calcite. These solids can be sorbents for U(VI), but can also act as coatings and binding agents between silt/clay minerals that block U(VI) access to sites on the silt/clay minerals with higher sorption affinity (Bernhard et al., 2001; Dong et al., 2005; Fox et al., 2006; Reeder et al., 2001; Reeder et al., 2000; Zachara et al., 1991; Zheng et al., 2003). To characterize these impacts, we analyzed organic and inorganic carbon content and used the inorganic carbon content to grossly estimate calcite content.

Total carbon and total organic carbon contents in the solid samples were measured by the Coulometric method (combustion furnace: CM5030; $\mathrm{CO}_{2}$ Coulometer: Model 5012, UIC Coulometrics Inc., IL). Prior to measurement of total organic carbon, the samples were treated with $1 \mathrm{M} \mathrm{HCl}$ to remove the inorganic carbonate and dried at $80^{\circ} \mathrm{C}$. The total inorganic carbon content was calculated as the difference of total carbon and total organic carbon. Calcite content was calculated by roughly assuming that the total inorganic carbon was contributed by calcite only. Details of carbonate measurements are given in Protocol B of Appendix II.

Free Iron Oxides Content. The free iron oxides were measured using citrate-dithionite method (Ross and Wang, 1993). Details of this method are described in Protocol B of Appendix II. The extracted iron in the sodium citrate- dithionite solution was measured by ICP-OES by PNNL.

Background U(VI) Content. The HSC material was a processed composite from RCRA Borehole 299-W22-48 in the depth between 42 and $44 \mathrm{~m}(138-144 \mathrm{ft})$ bgs. Acid extraction results of the materials of two bounding layers, at $136 \mathrm{ft}$ bgs and $146 \mathrm{ft} \mathrm{bgs}$ showed uranium contents of $>7.6 \mu \mathrm{g} / \mathrm{g}$ and $>8.7 \mu \mathrm{g} / \mathrm{g}$ respectively (Serne et al., 2002). Therefore, the HSC sample can be reasonably assumed to also have a uranium content of roughly $8 \mu \mathrm{g} / \mathrm{g}$. The HSC silt/clay fraction was measured for background U(VI) by means of a nitric acid extraction method was adopted. A 15.75 mole/L (67\% by mass) nitric acid solution was used to do the extraction in a microwave digester (Microwave Accelerated Reaction System, Model MARS, CEM Corp., Matthews, NC). 0.5g sample ( $\mathrm{n}=2)$ was heated at $80^{\circ} \mathrm{C}$ for 10 minutes at a solid/acid solution of $100 \mathrm{~g} / \mathrm{L}$. Extracted U(VI) in the 
acid solution was diluted and measured by Kinetic Phosphorescence Analyzer (KPA-11, ChemChek Instr., Richland, WA).

Background Labile U(VI) Content. The background uranium exists in the sediment mostly as uranium minerals such as uranophane $\left(\mathrm{Ca}\left[\mathrm{UO}_{2}\left(\mathrm{SiO}_{3} \mathrm{OH}\right)\right]\left(\mathrm{H}_{2} \mathrm{O}\right)_{5}\right)$ and Naboltwoodite $\left(\mathrm{Na}\left[\mathrm{UO}_{2}\left(\mathrm{SiO}_{3} \mathrm{OH}\right)\right]\left(\mathrm{H}_{2} \mathrm{O}\right)_{1.5}\right)$, or in more stable mineral phases (such as $\mathrm{Fe} / \mathrm{Mn}$ minerals). However, a fraction of the uranium is adsorbed to the surface and/or precipitated as uranium salts (dissolvable in water) when the pore water was dried during the material processing. Such uranium can also participate in the adsorption/desorption equilibrium and can be defined as "labile" (Davis et al., 2002; Kohler et al., 2004), "accessible" (Payne et al., 1994) or "exchangeable" U(VI). This fraction is presumed to participate in the adsorption/desorption calculations.

To quantify the amount of "labile" uranium, various techniques can be applied. These techniques include the isotopic exchange method (Kohler et al., 2004; Payne et al., 1994), which uses a known distribution of uranium isotopes to probe exchangeable adsorption sites; the extraction method by Tamms acid oxalate (TAO), which is a part of a five-step extraction method to remove amorphous minerals of Fe, Al, Si and secondary $\mathrm{U}$ minerals (Payne and Waite, 1991); and the extraction by a bicarbonate-carbonate solution(CARB) (Curtis et al., 2004; Davis et al., 2004; Kohler et al., 2004), which uses a $\mathrm{NaHCO}_{3}$ $\mathrm{Na}_{2} \mathrm{CO}_{3}-\mathrm{NaNO}_{3}$ solution system at $\mathrm{pH}=9.45$ and $\mathrm{I}=0.022 \mathrm{M}$ to extract exchangeable $\mathrm{U}(\mathrm{VI})$ over an extraction period of 2 weeks. The CARB extraction method has been reported to give comparable results of the background "labile" U(VI) to those by the isotopic exchange method (Kohler et al., 2004).

However, the isotopic exchange method either requires the use of gammaspectroscope (Payne et al., 1994), or requires very long equilibration timed (e.g.10 months by Kohler et al. (2004)). The TAO method can attack a variety of minerals (such as iron-rich chlorite and biotite, magnetite, maghemite and some secondary manganese minerals), thus introducing quenching species that interfere with KPA measurements of $\mathrm{U}(\mathrm{VI})$. A modification of the CARB extraction method was chosen for use in our work, owing to laboratory difficulties associated with the other two methods.

Our modification of the CARB method applied a U-free, carbonate-bicarbonate buffered solution at $\mathrm{pH} 9.4 \pm 0.1, \mathrm{I}=0.05$ mole eq/L. The solution was kept saturated with atmospheric $\mathrm{CO}_{2}\left(\mathrm{P}_{\mathrm{CO} 2}=10^{-3.5} \mathrm{~atm}\right)$ and hold in equilibrium with calcite solids. This solution is only slightly different from the CARB solution in ionic strength. HSC silt/clay samples (n=3) using solid/water ratio of $40 \mathrm{~g} / \mathrm{L}, 100 \mathrm{~g} / \mathrm{L}$ and $200 \mathrm{~g} / \mathrm{L}$ were extracted with this solution for 2 weeks, which was the same length of time as for the CARB method (Kohler et al., 2004).

After two weeks of extraction, the samples were centrifuged and the supernatant was decanted for U(VI) measurement by KPA. Again, fresh extraction solution was added to the remaining solids to continue with the extraction for another week. After this second extraction, two more similar extractions were performed on these samples and the extracted U(VI) was measured after each extraction. 
Another set of extractions was conducted using the same extraction solution and a total of 6 extractions, with each extraction lasting for 3 days. The solid concentrations used were $95 \mathrm{~g} / \mathrm{L}$ and $182 \mathrm{~g} / \mathrm{L}$. This set of experiments were performed to more closely mimic the the sorption/desorption experiments which were also conducted at $\mathrm{pH} 9.4( \pm$ 0.1 ). For the sorption experiments, 4 pre-equilibration washings were used to equilibrate the solid samples to the desired $\mathrm{pH}$, as directly simulated by the first 4 extractions. When control samples with no U(VI) were used for the sorption phase and desorption phase, each lasting for 3 days, these control samples also underwent "equilibration" and "desorption" steps that followed the same procedure as the $5^{\text {th }}$ and the $6^{\text {th }}$ extraction. Therefore, this set of extractions can also serve as additional controls for the sorption/desorption experiment. Details of the sorption/desorption procedure are given in Part II and III of this report.

\section{Results and Discussion.}

Measurement results for cations and anions in the DI (Mili-Q) water equilibrated with the original HSC, the HSC silt/clay size fraction and the carbonate-free silt/clay are listed in Table I.1. These results showed that calcium content in the carbonate-removed HSC silt/clay was much lower than that in the original HSC and HSC silt/clay samples, as expected following removal of calcium from the silt/clay sample by the carbonateremoval procedure. However, all other cations showed higher concentration in the solution. This was probably caused by the dissolution of amorphous minerals by the acetic acid (HOAc) in the NaOAc-HOAc solution, and by ion exchange with the excessive amount of $\mathrm{Na}$ in the $\mathrm{NaOAc}-\mathrm{HOAc}$ solution.

Table I.1 Dissolved cations concentrations ( $\mathrm{ppm}$ ) from solid samples after equilibrating with deionized (Mili-Q) water. Solid/solution $=100 \mathrm{~g} / \mathrm{L}, 3$ days of equilibration time used. Data measured by ICP-OES by PNNL.

\begin{tabular}{|l|c|c|c|c|c|c|c|}
\hline Samples & $\mathrm{Al}$ & $\mathrm{Ca}$ & $\mathrm{Fe}$ & $\mathrm{K}$ & $\mathrm{Mg}$ & $\mathrm{Na}$ & $\mathrm{Si}$ \\
\hline Original HSC & $0.003^{*}$ & 0.35 & $0.014^{*}$ & 0.066 & 0.10 & $0.20^{*}$ & 0.29 \\
\hline HSC silt/clay & $0.003^{*}$ & 0.35 & $0.002^{*}$ & 0.069 & 0.12 & $0.18^{*}$ & 0.21 \\
\hline $\begin{array}{l}\text { Carbonate-free } \\
\text { HSC silt/clay }\end{array}$ & 0.63 & 0.04 & 0.74 & 0.05 & 0.24 & 0.86 & 2.50 \\
\hline
\end{tabular}

*Values analyzed below instrument EQL.

Some of the characterization data of the solids are listed in Table I.2. As shown by this table, contents of organic carbon were very low in all materials. The inorganic content, if assumed to be calcite, would account for $\sim 3 \%$ by weight. ICP-OES analysis of extracted iron showed that the contents of ion oxide minerals in the HSC and HSC silt/clay fraction were very low $(<1 \%)$. These results indicated that iron minerals and organic matter were not potential major adsorbents for U(VI) in these materials. Calcite could still be important in the sorption of U(VI) despite of its low mass content, because it could exist as surface coatings on the surfaces of clay minerals, thereby providing 
sorption surface but blocking potentially stronger U(VI) sorption sites on the mineral surfaces.

Table I.2 Characterization of the HSC and HSC silt/clay fraction. All contents are mass based percentages

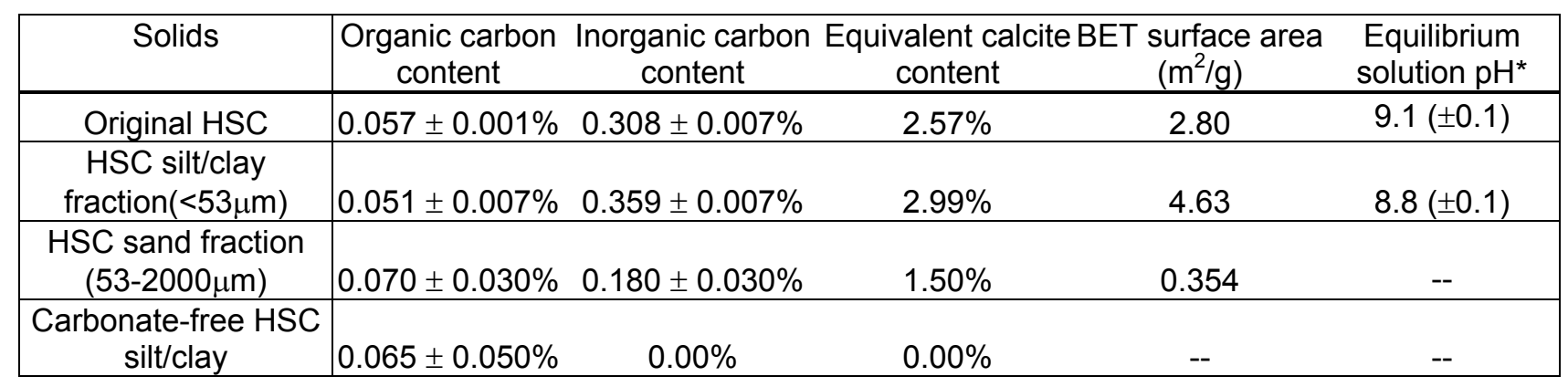

${ }^{*}$ The equilibration solution is obtained by using DI water (solid/solution $=100 \mathrm{~g} / \mathrm{L}$ ) to equilibrate with the materials.

The concentration of U(VI) in the "pristine" HSC silt/clay sample that could be extracted by $15.8 \mathrm{~mole} / \mathrm{L} \mathrm{HNO}_{3}$ was $0.87 \pm 0.05 \mu \mathrm{g} / \mathrm{g}$. However, this might only represent a fraction of the total background U(VI) in the solids because the acid could not fully dissolve U contained within rock fragments (Curtis et al., 2004; Serne et al., 2002). A similar extraction study (Serne et al., 2002) on materials in neighboring layers of the same sampling borehole revealed that the U(VI) extracted by heated 8 mole/L nitric acid accounted for only $9.1 \%$ to $>40.8 \%$ of total U(VI) measured by X-Ray Fluorescence (XRF). Thus, the content of total background U(VI) could be 2.5 to 10 times as high as $0.87 \mu \mathrm{g} / \mathrm{g}$.

Figure I.1 shows the extraction results of background labile U(VI) using the carbonate-bicarbonate extractions, similar to the CARB method. While the amounts of background labile U(VI) extracted using $100 \mathrm{~g} / \mathrm{L}$ and $40 \mathrm{~g} / \mathrm{L}$ were close, the amount extracted by using $400 \mathrm{~g} / \mathrm{L}$ of solid/liquid ratio was much lower than those of the other two systems. This was probably caused by the fact that at this higher solid concentration, the solution phase had a higher U(VI) concentration due to the smaller volume of solution, and some labile U(VI) was re-sorbed to the solids. Therefore, the $40 \mathrm{~g} / \mathrm{L}$ results were chosen for calculation of background labile U(VI). Figure I.1 clearly shows, however, that the cumulative amount of extracted U(VI) continued to increase with each time of extraction. Accumulated amount with each extraction time was $70.8 \pm 3.7 \mathrm{ng} / \mathrm{g}$, $80.3 \pm 3.8 \mathrm{ng} / \mathrm{g}, 88.5 \pm 4.0 \mathrm{ng} / \mathrm{g}, 99.2 \pm 4.1 \mathrm{ng} / \mathrm{g}, 104.3 \pm 4.1 \mathrm{ng} / \mathrm{g}$ respectively.

Results of the six 3-day extractions are listed in Table I.3. These extractions also showed that more background U(VI) was released with each additional extraction. Because the extraction was equivalent to a sorption/desorption equilibration procedure at $\mathrm{pH} 9.4$, the results indicated that more U(VI) became labile (i.e. available to participate in sorption/desorption equilibrium) with each extraction. Therefore, although the CARB method (Kohler et al., 2004) proposes that the labile background U(VI) is the amount extracted by one extraction for 2 weeks, the results of our work suggest that additional background labile U(VI) may become available with each new addition of extraction 
solution. This can be caused by the dissolution of U(VI) minerals from the solids. If so, the amount of $\mathrm{U}(\mathrm{VI})$ that dissolves to become labile is dependent on the $\mathrm{pH}$ of the extraction solution, because the dissolution of U(VI) minerals is dependent on solution pH (Liu et al., 2004; Liu et al., In press; McKinley et al., 1995; Serne et al., 2002).

As already pointed out, for the sorption/desorption experiments on the HSC silt/clay at $\mathrm{pH} 9.4 \pm 0.1$, the fifth and sixth 3-day extractions are equivalent to the sorption and desorption stages of the sorption/desorption experiments with no external U(VI) being added. Therefore, the U(VI) extracted in these steps is taken to be representative of the effective labile U(VI) for the sorption/desorption at $\mathrm{pH} 9.4 \pm 0.1$. The cumulative background U(VI) extracted by the six extractions, $94.9 \mathrm{ng} / \mathrm{g}$, might be taken to represent the total background labile U(VI) for sorption/desorption at $\mathrm{pH} 9.4 \pm 0.1$.

For the sorption/desorption experiments at $\mathrm{pH} 9.4( \pm 0.1)$, however, 4 preequilibration washings were used. Therefore, the background labile U(VI) washed off by these washings is deducted from the total labile background value to determine the available labile amount during sorption. From Table I.3, the labile background U(VI) concentration left after pre-equilibration is $11.86 \mathrm{ng} / \mathrm{g}$ and $25.92 \mathrm{ng} / \mathrm{g}$ for $95 \mathrm{~g} / \mathrm{L}$ and $182 \mathrm{~g} / \mathrm{L}$ samples, respectively.

As already discussed, the effective background labile U(VI) content of a solid material is dependent on the $\mathrm{pH}$ value of the system, and the values given above are relevant for studies at $\mathrm{pH} 9.4 \pm 0.1$. The determination of effective background labile $\mathrm{U}(\mathrm{VI})$ at $\mathrm{pH} 8.0$ is discussed in Part IV of this report.

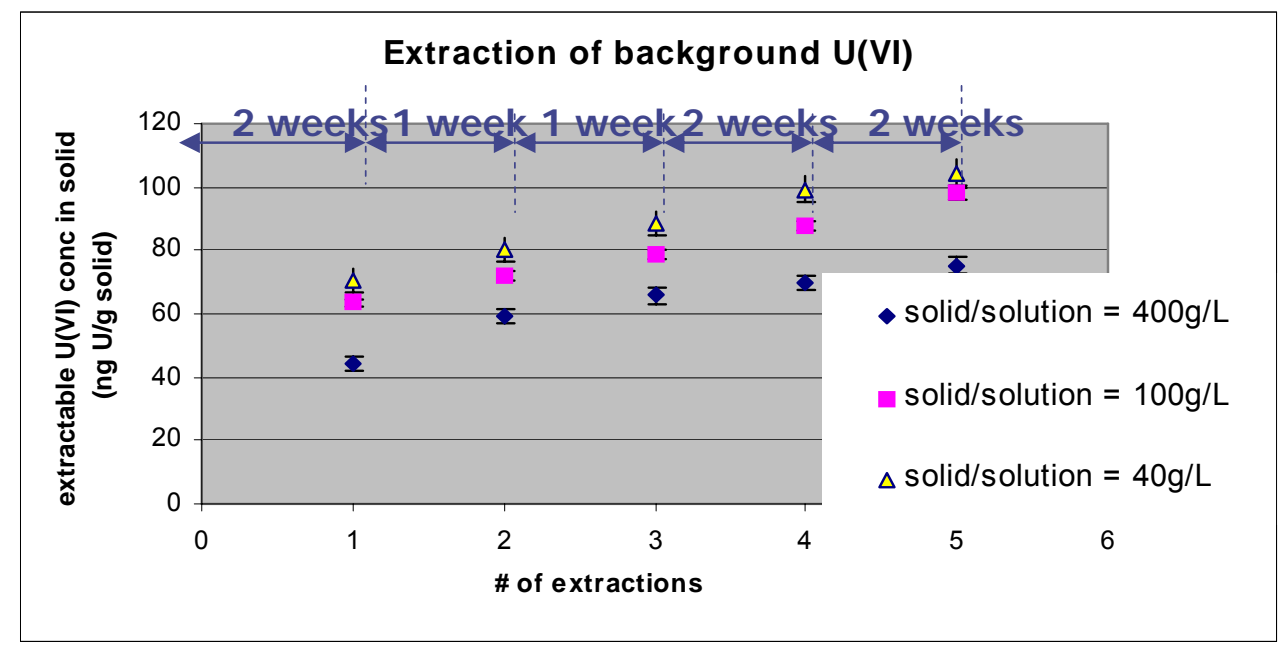

Figure I.1 Extraction of background labile U(VI) using a carbonate-bicarbonate solution. Various solid/solution ratios used. 


\begin{tabular}{|c|c|c|c|c|}
\hline & \multicolumn{2}{|c|}{$\begin{array}{c}\text { Sample background in sorption } \\
\text { experiment } \\
\text { (soil/solution= 95g/L) }\end{array}$} & $\begin{array}{c}\text { Sample background in sorption } \\
\text { experiment } \\
\text { (soil/solution=182g/L) }\end{array}$ \\
\hline Procedures & $\begin{array}{c}\text { leached U(VI) } \\
\text { ug/L }\end{array}$ & $\begin{array}{c}\text { converted } \\
\mathrm{U}(\mathrm{VI}) \mathrm{ng} / \mathrm{g}\end{array}$ & $\begin{array}{c}\text { leached U(VI) } \\
\text { ug/L }\end{array}$ & $\begin{array}{c}\text { converted U(VI) } \\
\mathrm{ng} / \mathrm{g}\end{array}$ \\
\hline $1^{\text {st }}$ extraction pH 9.4 \pm 0.1 & 4.9 & 48.6 & 8.1 & 40.5 \\
$2^{\text {nd }}$ extraction pH 9.4 \pm 0.1 & 1.6 & 62.46 & 3.3 & 54.12 \\
$3^{\text {rd }}$ extraction pH 9.4 \pm 0.1 & 1.1 & 72.98 & 1.8 & 62.22 \\
$4^{\text {th }}$ extraction pH 9.4 \pm 0.1 & 1.0 & $\mathbf{8 3 . 0 4}$ & 1.4 & 68.98 \\
$5^{\text {th }}$ extraction $\mathrm{pH} 9.4 \pm 0.1$ & 0.6 & 89.13 & 0.9 & 73.18 \\
$6^{\text {th }}$ extraction $\mathrm{pH} 9.4 \pm 0.1$ & 0.6 & $\mathbf{9 4 . 9 0}$ & 1.2 & 79.36 \\
\hline
\end{tabular}

Table I.3 Results of background labile $\mathrm{U}(\mathrm{VI})$ extraction by 6 extractions each lasting 3 days.

\section{Summary of Part I.}

In this part of study, the original HSC and the HSC silt/clay and size fractions were characterized in terms of the surface area, carbonate content, free iron oxide content, and cation concentrations in equilibration solution. The HSC silt/clay fraction was also studied for its background U(VI) that was extractable by $15.75 \mathrm{M}$ hot nitric acid, and its labile background U(VI). These characterizations provide useful information for other aspects of the project.

To obtain the labile background U(VI), a pH 9.4 carbonate/bicarbonate solution extraction method was used similar to the CARB method described in literature (Curtis et al., 2004; Davis et al., 2004; Kohler et al., 2004). However, results of our work suggest that more background U(VI) can e removed when multiple extraction solutions are used. This can be caused by the dissolution of U(VI) minerals from the solids. If so, the amount of dissolved $\mathrm{U}(\mathrm{VI})$ can become labile, and dependent on the $\mathrm{pH}$ of the extraction solution, because the dissociation of U(VI) from the solids is dependent on solution $\mathrm{pH}$. This suggest that, in order to determine total background labile U(VI) for sorption studies with a given sediment sample, the $\mathrm{pH}$ of the solution for $\mathrm{U}(\mathrm{VI})$ reaction and the history of the processing of the solids should be duplicated and the background labile U(VI) content directly determined for the specific conditions encountered. These findings reveal that additional complexities exist beyond those reported in prior literature for the determination of background labile (or accessible, exchangeable) U(VI), and that such complexities should be considered in the study of U(VI) sorption/desorption.

In addition to the characterization of the sediment materials, a carbonate-free HSC silt/clay material and an iron mineral-free HSC silt/clay material were prepared in this part of the work, These materials were used in Part III of this project. 


\section{Part II Study of Influence of Calcite and Dissolved Calcium on U(VI) Sorption}

This part of the study has been published in the following peer-reviewed journal publication "Influence of calcite and dissolved calcium on uranium(VI) sorption to a Hanford subsurface sediment ", in Environmental Science \& Technology, Vol 39, pp 7949-7955, 2005. This paper is attached as Appendix I of this report. 


\section{Part III. Study of U(VI) Sorption/Desorption at pH $9.4( \pm 0.1)$ and the Effects of Solid-to-Solution Ratio}

\section{Introduction}

Sorption is an important retardation process involved in the transport of uranium(VI) in the subsurface sediments of the DOE Hanford site, WA. Accurate understanding of the U(VI) sorption behavior is crucial to the evaluation of U(VI) mobility. So far, many of the U(VI) sorption studies on sediment materials from Hanford site and from other U(VI) contamination sites that has similar sediment characteristics and groundwater compositions have been conducted at $\mathrm{pH}$ less than 8.5(Barnett et al., 2002; Curtis et al., 2006; Curtis et al., 2004; Dong et al., 2005; Gamerdinger et al., 2001; Qafoku et al., 2005; Tokunaga et al., 2004; Zheng et al., 2003), however, studies for $\mathrm{U}(\mathrm{VI})$ sorption characteristics at higher $\mathrm{pH}$ values have been few (Kaplan et al., 1998; Liu et al., 2004; Tokunaga et al., 2005; Tokunaga et al., 2004). Because higher pH values have been found to exist at Hanford, especially in the contaminated area where highly alkaline plumes was discharged into the subsurface in the past (Liu et al., 2004; Liu et al., In press; McKinley et al., 1995; Serne et al., 2002), more work is needed to investigate $\mathrm{U}(\mathrm{VI})$ sorption/desorption behavior at higher $\mathrm{pH}$.

To model U(VI) reactive transport in subsurface sediments, the partition of U(VI) between the solid and solution phase must be quantified. A common way to quantify such partition in engineering practice is to conduct batch experiments to obtain sorption isotherms which relate U(VI) concentrations in the two phases by linear or non-linear relationships (Barnett et al., 2002; Dong et al., 2005; Qafoku et al., 2005; Zheng et al., 2003). In most batch systems, the solid-to-solution ratio (SSR) is typically lower than that of the porous media from the in-situ environment. Therefore, evaluation of the effects of SSR on batch-obtained U(VI) isotherms is required. The batch isotherms should only be considered as applicable to the sorption in subsurface sediments when U(VI) sorption is demonstrated to be independent of SSR (Bethke and Brady, 2000; Cheng et al., 2006). Our previous studies of U(VI) sorption to the Hanford Silt Composite (HSC) sediment and its silt/clay fraction at $\mathrm{pH} 8.0( \pm 0.1)$ and $8.4( \pm 0.1)$ have shown that $\mathrm{U}(\mathrm{VI})$ sorption at these $\mathrm{pH}$ values was over $80 \%$ reversible and independent of SSR (refer to Part II and Part IV). However, because U(VI) sorption often decreases at $\mathrm{pH}>8-9$ when carbonate is present in the solution phase (Arai et al., 2006; Chisholm-Brause et al., 2001; Kaplan et al., 1998), effects of influencing factors including SSR may become more significant at higher $\mathrm{pH}$ (i.e. U(VI) sorption is more sensitive to these factors). In this investigation, we studied the sorption behavior of $\mathrm{U}(\mathrm{VI})$ at $\mathrm{pH} 9.4( \pm 0.1)$, and examined the effect of SSR on $\mathrm{U}(\mathrm{VI})$ sorption at this $\mathrm{pH}$. Our objective was to provide information for the better understanding and prediction of U(VI) sorption and transport at high $\mathrm{pH}$ and evaluate the applicability of the isotherms obtained at low SSR (e.g. in the batch system) to the in-situ environment where the SSR is much higher. Such information will aid in the study of $\mathrm{U}(\mathrm{VI})$ transport and fate for the contaminated, highly alkaline Hanford areas.

\section{Materials and Methods}

Materials. The sediment material, Hanford Silt Composite (HSC, RCRA Borehole \#299-W22-48, DOE Hanford Site, WA) was wet-sieved into various size 
fractions as described in Part I. The silt/clay (SC) fraction is used for the experiments in this part of work. For batch experiments, the silt/clay material was pre-equilibrated by a U-free electrolyte solutions at $\mathrm{pH} 9.4( \pm 0.1)$, buffered by $\mathrm{Na}_{2} \mathrm{CO}_{3}-\mathrm{NaHCO}_{3}$ and adjusted by $\mathrm{HNO}_{3} / \mathrm{NaOH}, \mathrm{I}=0.05 \mathrm{M}\left(\mathrm{NaNO}_{3}\right.$ as support electrolyte), saturated with atmospheric $\mathrm{CO}_{2}\left(\mathrm{P}_{\mathrm{CO} 2}=10^{-3.5} \mathrm{~atm}\right)$ and with respect to calcite solids. Four pre-equilibration washes were used to the solids with a SSR of $100 \mathrm{~g} / \mathrm{L}$ or $200 \mathrm{~g} / \mathrm{L}$, each lasting for 3 days. The $\mathrm{pH}$ of the washing solution was stabilized to $\mathrm{pH} 9.4( \pm 0.1)$ after the pre-equilibration.

Kinetics and effects of SSR. Preliminaray sorption experiments were performed at SSR of $333 \mathrm{~g} / \mathrm{L}$ to determine the time needed for sorption to reach equilibrium. To test the effects of SSR on U(VI) sorption/desorption, SSR values of $95 \mathrm{~g} / \mathrm{L}, 182 \mathrm{~g} / \mathrm{L}$ and $333 \mathrm{~g} / \mathrm{L}$ were used in batch sorption experiments. Desorption of the sorbed U(VI) was performed after the sorption was finished, using the same SSR. Sufficient equilibration time (3-6 days) was used for both sorption/desorption. Details of sorption/desorption procedures were the same as described in Part II of this report, except that the solid samples were pre-equilibrated 4 times, for 3 days each time, and the equilibrated batch reaction systems were centrifuged at $4000 \mathrm{rcf}$ for 45 minutes.

Test of Solid/Liquid Separation Method. Like most clayey materials, HSC silt/clay contains a certain amount of very fine (colloidal) solid particles that may not be completely separated from the solution phase by centrifugation. Since such colloidal particles have large surface areas, they will also take up some U(VI), and if this colloidal phase U(VI) is measured together with the solution phase U(VI), it will cause underestimation of sorption in the calculation of sorption/desorption isotherms. This phenomena can be particularly important when U(VI) sorption to the solid phase is low, such as for our studies at high $\mathrm{pH}$. To evaluate the possibility of such effects, we compared results under normal centrifugation, high-speed centrifugation, filtration and ultra-filtration experiments were conducted to examine the effect of incomplete separation of the colloids on the measurement of solution phase U(VI). Samples at SSR values of $95 \mathrm{~g} / \mathrm{L}, 182 \mathrm{~g} / \mathrm{L}$ and $333 \mathrm{~g} / \mathrm{L}$ were tested. For each SSR, two batch sorption samples were centrifuged at $4500 \mathrm{rcf}(\mathrm{g})$ for 45 minutes, and then again at $16000 \mathrm{rcf}$ for 20 minutes (Centrifuge 5417C, Eppendorf, Hamburg, Germany). Another two samples were centrifuged at $4500 \mathrm{rcf}$ for 45 minutes, and then filtered through $0.2 \mu \mathrm{m}$ membrane (Corning Inc., Corning, NY). After that, ultra-filtration was applied to the filtered supernatant using 3kDalton membrane filter paper (Diaflo, Amico Inc., Berverly, MA) in a ultra-filtration device (Stirr Cell: Model 8050, Stirrer: Modle MT2, Amicon, Damers, MA ). U(VI) concentration in the supernatant of the samples was measured after each step of the operations.

Isotherm Experiments. Isotherm experiments were conducted using SSR of $95 \mathrm{~g} / \mathrm{L}$ and $333 \mathrm{~g} / \mathrm{L}$, with $\mathrm{U}(\mathrm{VI})$ concentration ranging from 0.24 to $23.4 \times 10^{-6} \mathrm{~mole} / \mathrm{L} .3$ days of equilibration time were used for both SSR's. Because U(VI) sorption was low at high $\mathrm{pH}(<10 \%)$, greater error could be caused in the estimation of sorbed U(VI) due to subtraction of two numbers having very close values - initial U(VI) concentration and equilibrium concentration. To increase accuracy, two independent batches of sorption experiments were conducted. For the $95 \mathrm{~g} / \mathrm{L}$ systems, triplicate samples were used for 
both batches, and for the $333 \mathrm{~g} / \mathrm{L}$ system, duplicate samples were used for both batches. All samples were rotated end-over-end on a bench-top rotating device for 3 days, after which the batch systems were centrifuged at $4000 \mathrm{rcf}$ for 45 minutes and U(VI) concentration in the supernatant measured. $\mathrm{Ca}, \mathrm{Mg}, \mathrm{Fe}$ and $\mathrm{Al}$, and silicon contents in the supernatants of several of the $95 \mathrm{~g} / \mathrm{L}$ and $333 \mathrm{~g} / \mathrm{L}$ batch systems (those with initial $\mathrm{U}(\mathrm{VI})=$ 1.0 and $7.5 \times 10^{-6} \mathrm{M}$ ) were also measured.

Flow-through column experiments. In addition to the batch sorption equilibrium study, two flow-through columns were constructed to study U(VI) sorption where solid particles were packed to a compactness that was more like the in-situ condition. Figure III.1 illustrates the setup of the columns. About 4.5-5.5 gram of the HSC silt/clay was pre-equilibrated at $\mathrm{SSR}=\sim 100 \mathrm{~g} / \mathrm{L}$ by the same procedure as for the batch samples, until a stable $\mathrm{pH}$ of $9.4( \pm 0.1)$ was acieved. After pre-equilibration, the soil sample was dried and then evenly divided into 16 parts by a 16-Way Spinning Riffler (Gilson Company Inc, Worthington, OH). These aliquots were then packed as lofts into a $2.6 \mathrm{~cm}$ ID polypropylene cylinder to form a plug of sediment. In order to hold the sediment plug in place, $1 \mathrm{~mm}$ non-reactive glass beads were filled in on the top of the sediment, separated from the sediment by a 0.4 um membrane and a stainless steel screen,. The sediment was also separated from the rubber plug at the influent end by a similar $0.4 \mathrm{um}$ membrane and stainless steel screen. Stock U(VI)-laden solution from a reservoir was circulated through the columns for long enough for U(VI) to reach sorption equilibrium. To compare to the batch system, the mass ratio of the silt/clay in the column and the total volume of U(VI) solution in the reservoir was designed to be approximately $100 \mathrm{~g} / \mathrm{L}$. The purpose of this design was to maintain a very high SSR at the local environment in the flow-through system while keeping the overall mass ratio of solids to solution roughly the same as in the $95 \mathrm{~g} / \mathrm{L}$ batch systems. The latter arrangement should maintain very similar concentrations of aqueous systems between this "high SSR" column and the "low SSR" $(95 \mathrm{~g} / \mathrm{L})$ batch system.

Following the onset of circulation through the column, U(VI) concentration was monitored over time until equilibrium was reached. Table III.1 shows the operating conditions and physical characteristics of the columns.

Table III.1 Operation data of the flow-though columns for $\mathrm{U}(\mathrm{VI})$ sorption study.

\begin{tabular}{||l|r|r|}
\hline Column Operation Data & column I & column II \\
\hline mass of soil $(\mathrm{g})$ & 5.9972 & 4.6614 \\
\hline total solution volume $(\mathrm{mL})$ & 63.75 & 46.76 \\
\hline total operation time $(\mathrm{hrs})$ & 240 & 240 \\
\hline flow rate $(\mathrm{mL} / \mathrm{min})$ & 0.086 & 0.093 \\
\hline pore volume $(\mathrm{mL})$ & 2.147 & 1.061 \\
\hline total pore volumes & 575.22 & 1256.68 \\
\hline
\end{tabular}

Measurements. U(VI) concentration was measured by Kinetic Phosphorescence Analyzer (KPA-11, ChemChek Instr., Richland, WA). The KPA-11 has an effective detection limit of $0.1 \times 10^{-6} \mathrm{~g} / \mathrm{L}(\mathrm{ppb})$. Calcium concentration in the sorption solution at equilibrium was measured by AAS (AAnalyst 100, PerkinElmer, Suwanee, GA). 
Magnesium, ion, aluminum, and silicon concentrations in the sorption solution was measured by ICP-MS (Elan DRC II, Perkin Elmer Sciex, Suwanee, GA).

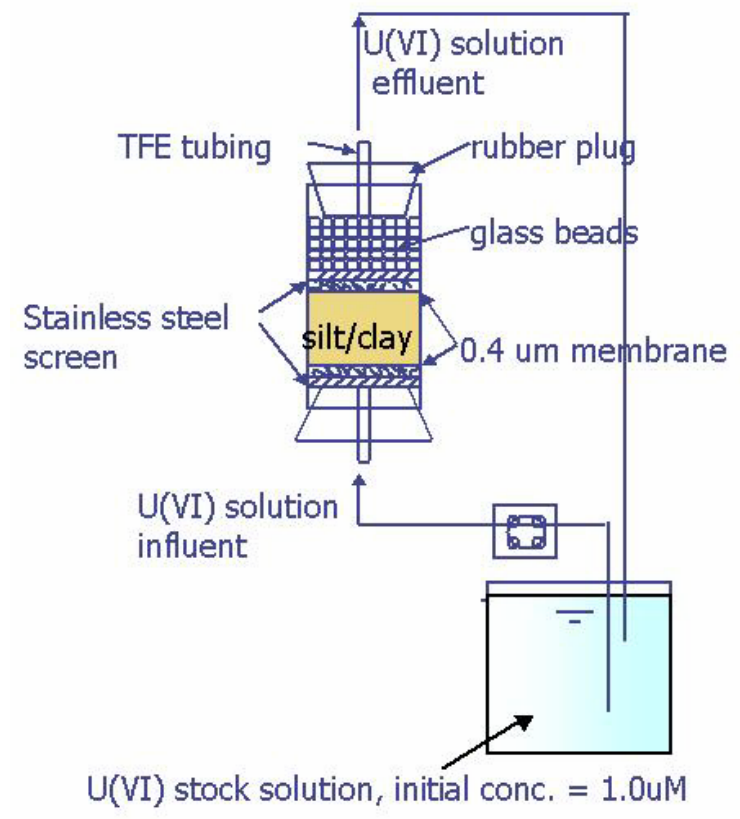

Figure III.1 Illustration of column setup for $\mathrm{U}(\mathrm{VI})$ sorption study.

\section{Results and Discussion}

Sorption kinetic experiments (Figure III.2) showed that U(VI) reached sorption equilibrium very quickly ( $<10$ hours). Therefore, the 3-6 days of sorption and desorption time in the sorption/desorption isotherm experiments was enough for the system to reach equilibrium. These result are similar to the sorption kinetic results obtained at $\mathrm{pH} 8.0$ $( \pm 0.1)$, as reported in Part II (see Supporting Information of Part II).

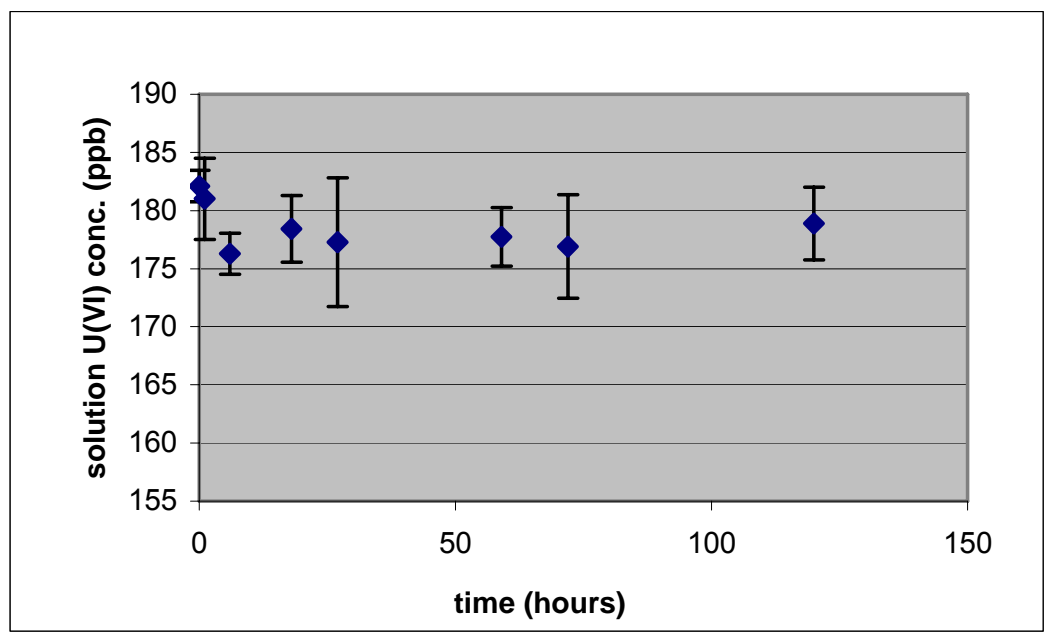

Figure III.2 $\mathrm{U}(\mathrm{VI})$ sorption kinetics experiments. Data show $\mathrm{U}(\mathrm{VI})$ concentration change in the batch sorption system. $\mathrm{pH}=9.4( \pm 0.1), \mathrm{I}=0.05 \mathrm{M}$, system saturated with atmospheric $\mathrm{CO}_{2}\left(\mathrm{P}_{\mathrm{CO} 2}=\right.$ $10^{-3.5} \mathrm{~atm}$ ) and calcite solid, SSR $=333 \mathrm{~g} / \mathrm{L}, \mathrm{T}=22.5^{\circ} \mathrm{C}$. Triplicate samples used. 
Figure III.3 shows results of the SSR test on U(VI) sorption/desorption. It was apparent that the sorption data (solid squares on the figure) for $95 \mathrm{~g} / \mathrm{L}, 182 \mathrm{~g} / \mathrm{L}$ and $333 \mathrm{~g} / \mathrm{L}$ systems at equilibrium could not be modeled by one single isotherm. The lower SSR system showed stronger uptake of U(VI) than the higher SSR system. Such strong dependence on the SSR was also observed in the desorption process for higher SSR systems, as seen in Figure III.3. The lower-SSR system (at 95g/L) system was apparently slower to release sorbed U(VI) back to the solution phase, thus exhibiting an effectively irreversible fraction of sorption at the time scale of the experiment. Isotherm models based on more extensive data obtained during other sorption isotherm experiments (details given later in this text) are also plotted on Figure III.3. As evident from the figure, the desorption data of the $333 \mathrm{~g} / \mathrm{L}$ system lie close to the sorption isotherm, indicating that the desorption of this system followed the sorption isotherm - i.e., that it was fully "reversible." For the $95 \mathrm{~g} / \mathrm{L}$ system, however, the desorption data point fell well above the sorption isotherm, suggesting incomplete desorption - i.e., apparent irreversibility of sorption

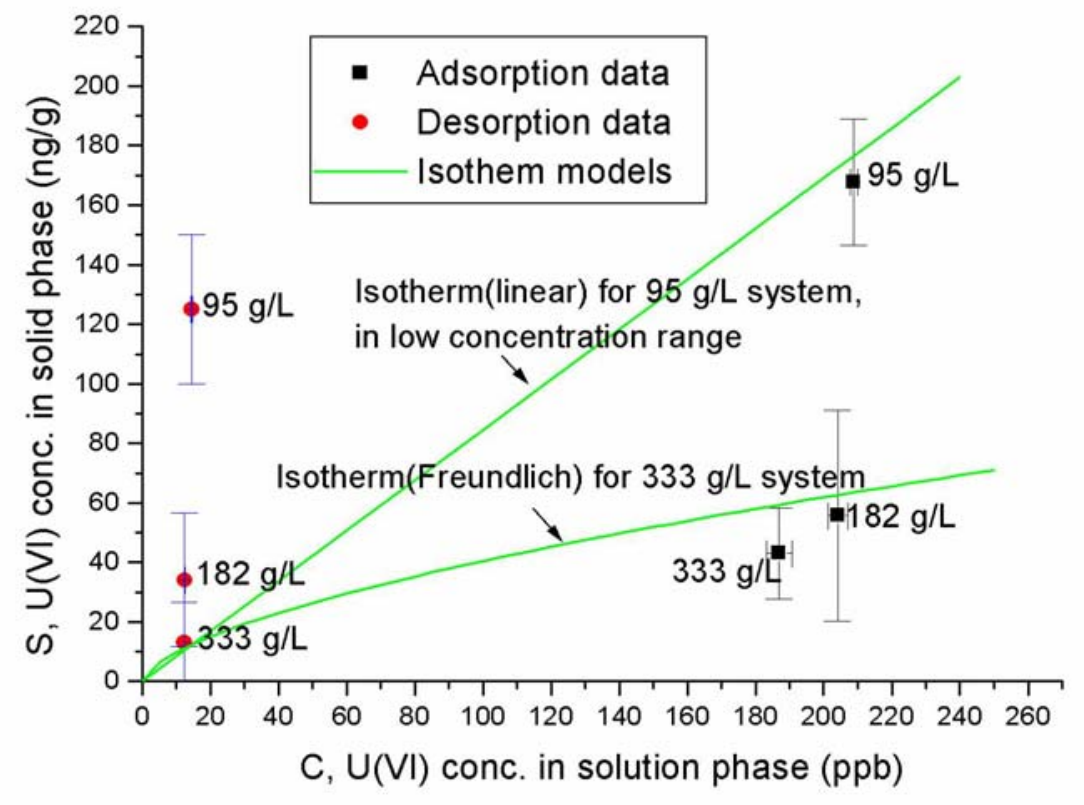

Figure III.3 Sorption/Desorption data for systems with solid-to-solution ratio of $95 \mathrm{~g} / \mathrm{L}, 182 \mathrm{~g} / \mathrm{L}$ and $333 \mathrm{~g} / \mathrm{L}$. $\mathrm{pH}=9.4( \pm 0.1), \mathrm{I}=0.05 \mathrm{M}$, system saturated with atmospheric $\mathrm{CO}_{2}\left(\mathrm{P}_{\mathrm{CO} 2}=10^{-3.5} \mathrm{~atm}\right)$ and calcite solid, $\mathrm{T}=22.5^{\circ} \mathrm{C}$. Triplicate samples used.

As shown in Figure III.4, sorption isotherm experiments conducted using $333 \mathrm{~g} / \mathrm{L}$ and $95 \mathrm{~g} / \mathrm{L}$ samples also showed distinct dependence of sorption on SSR, with the $95 \mathrm{~g} / \mathrm{L}$ system exhibiting stronger sorption. Such dependence was more obvious at U(VI) equilibrium concentrations below $1500 \mathrm{ppb}$ (initial $\mathrm{U}(\mathrm{VI})<6 \times 10^{-6} \mathrm{M}$ ). Isotherms generally showed monotonic increases of sorbed concentration with increasing $\mathrm{U}(\mathrm{VI})$ concentrations. At $\mathrm{U}(\mathrm{VI})$ equilibrium concentrations above $1500 \mathrm{ppb}$, however, the sorbed U(VI) concentration for the $95 \mathrm{~g} / \mathrm{L}$ system leveled off at about $700 \mathrm{ng} / \mathrm{g}$. This phenomenon may suggest that the sorption sites saturate at roughly $700 \mathrm{ng} / \mathrm{g}$. For the 
$333 \mathrm{~g} / \mathrm{L}$ system, equilibrium $\mathrm{U}(\mathrm{VI})$ content in the solid phase was lower than that of the $95 \mathrm{~g} / \mathrm{L}$ system for most of the concentration range; however, at very low initial U(VI) (roughly $23 \times 10^{-6} \mathrm{~mole} / \mathrm{L}$ ), a similar level of equilibrium solid-phase U(VI) content was observed. Unlike the sorption data obtained at $\mathrm{pH} 8.0$ and 8.4 (see Part II and Part IV), sorption results at $\mathrm{pH} 9.4$ could not be modeled by a single conventional isotherm model over the whole concentration range studied. However, for equilibrium U(VI) concentrations less than $500 \mathrm{ppb}\left(\sim 2 \times 10^{-6} \mathrm{M}\right)$, the $95 \mathrm{~g} / \mathrm{L}$ system sorption data could be approximately modeled by a linear isotherm and the $333 \mathrm{~g} / \mathrm{L}$ data could be approximately modeled by the Freundlich isotherm. These isotherms have been plotted in Figure III.3, where they were used to show the dependence of sorption on SSR and the irreversibility of the sorption, especially for the $95 \mathrm{~g} / \mathrm{L}$ system.

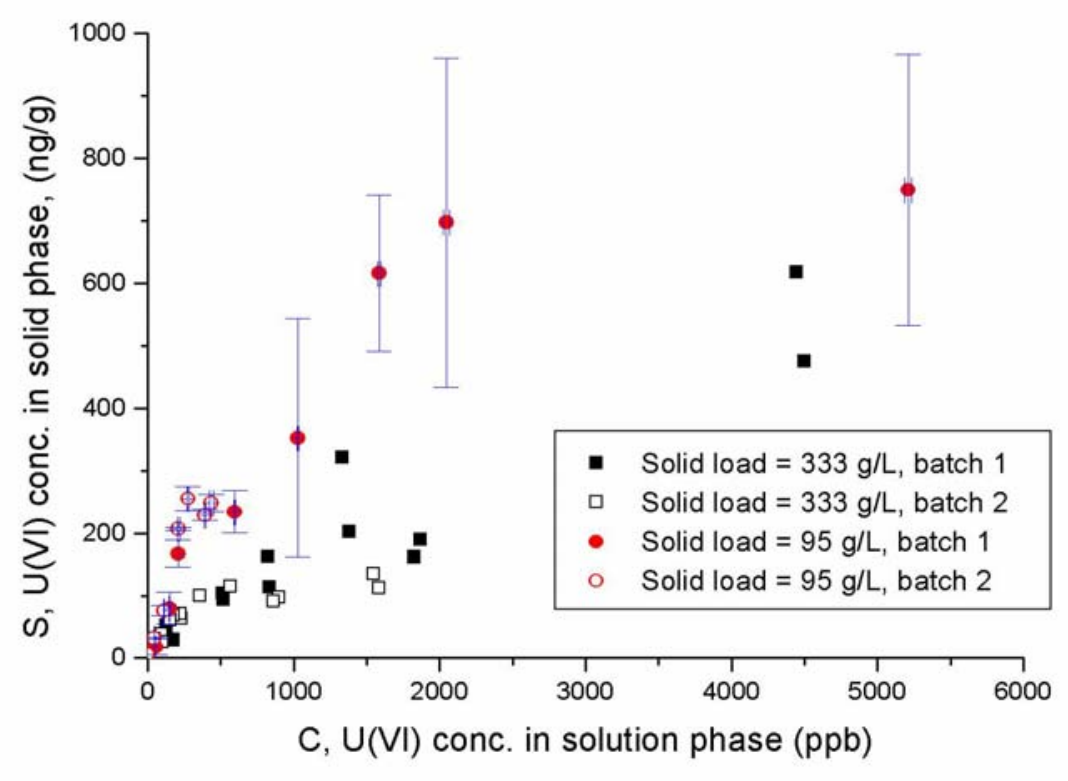

Figure III.4 Sorption isotherm data of $95 \mathrm{~g} / \mathrm{L}$ and $333 \mathrm{~g} / \mathrm{L}$ systems. $\mathrm{pH}=9.4( \pm 0.1), \mathrm{I}=0.05 \mathrm{M}$, system saturated with atmospheric $\mathrm{CO}_{2}\left(\mathrm{P}_{\mathrm{CO} 2}=10^{-3.5} \mathrm{~atm}\right)$ and calcite solid, $\mathrm{T}=22.5^{\circ} \mathrm{C}$. Two batches were performed for each SSR. Triplicate samples used for both batches of $95 \mathrm{~g} / \mathrm{L}$ systems; Duplicate samples used for both batches of 333g/L samples.

The cause of such dependence on the SSR is still unknown. One possible cause could be insufficient separation of solids (colloids) from liquid in the high SSR system because solution phase $\mathrm{U}(\mathrm{VI})$. However, results of the solid/liquid separation method test (Table III.2) showed that measured U(VI) concentration in the equilibrium solution remained at the same level after all the separation procedures. The U(VI) concentration of the $333 \mathrm{~g} / \mathrm{L}$ samples showed slight reduction after ultra-filtration compared to the results by centrifugation; however, the difference was found not significant by doing pair-wise ttest using a measurement error (by the KPA-11) of 3.5\%. This showed that removal of colloidal particles by ultra-filtration did not affect the observed U(VI) concentration,. These findings suggested that the low sorption at high SSR was not caused by the 
incomplete removal of colloidal particles, and centrifugation at $4000 \mathrm{rcf}$ was sufficient for separation of solids from the liquids in the batch sorption systems.

Table III.2. $\mathrm{U}(\mathrm{VI})$ concentrations in the equilibrated solution of the $\mathrm{pH} 9.4$ adsorption batch system after performing combinations of centrifugation and ultra-filtration. $\mathrm{U}(\mathrm{VI})$ concentration $\mathrm{C} 0$ $=236.4 \mathrm{ppb}$ at the start of the sorption experiments.

\begin{tabular}{|c|c|c|c|c|}
\hline SSR & $4000 \mathrm{rcf} 45 \mathrm{~min}$ & $\begin{array}{c}4000 \text { rcf 45min } \\
+16000 \mathrm{rcf} 20 \mathrm{~min}\end{array}$ & $\begin{array}{c}\text { 4000rcf 45min } \\
+0.2 \text { um filtration }\end{array}$ & $\begin{array}{l}\text { 4000rcf+0.2um filtration } \\
+ \text { 3KDalton ultra-filtration }\end{array}$ \\
\hline $95 \mathrm{~g} / \mathrm{L}$ & 216.3 & 224.7 & 226.9 & 209.7 \\
& 223.1 & 217.7 & 222.1 & 208.1 \\
\hline $182 \mathrm{~g} / \mathrm{L}$ & 212.2 & 214.7 & 201.1 & 202.1 \\
& 213.5 & 204.5 & 205.9 & 206.2 \\
\hline $333 \mathrm{~g} / \mathrm{L}$ & 187.9 & 193.8 & 188.2 & 184.2 \\
& 189.5 & 194.2 & 187.5 & 189.2 \\
\hline
\end{tabular}

Another possible explanation for the dependence on SSR was that in the high SSR system, the solid particles were more aggregated. Because U(VI) would sorb to the edges sites of the clay minerals (Bargar et al., 1999; Bargar et al., 2000; Davis et al., 2004; Liu et al., In press; Payne et al., 1994; Payne et al., 1998; Turner et al., 1996), such aggregation could cause blocking of these sites, thus lowering the sorptive capacity of the sediment solids. Results of the column experiments support this hypothesis. Here, the solid/solution partition coefficient $\mathrm{K}_{\mathrm{d}}$ was used for evaluation of sorptive capacity. $\mathrm{K}_{\mathrm{d}}$ was defined as $K_{d}=S_{e} / C_{e}\left[L^{3} / M\right]$, where $S_{e}$ was the equilibrium concentration of $U(V I)$ in the solid phase, and $\mathrm{C}_{\mathrm{e}}$ was the equilibrium concentration of $\mathrm{U}(\mathrm{VI})$ in the solution phase.

As shown in Table III.3, using similar overall solid loadings to the $95 \mathrm{~g} / \mathrm{L}$ batch system, Column I and II had lower $\mathrm{K}_{\mathrm{d}}$ values than the $95 \mathrm{~g} / \mathrm{L}$ batch system. This suggested that sorption was suppressed in the column system where the solid particles were more aggregated and a part of the surface sorptive sites became inaccessible to $\mathrm{U}(\mathrm{VI})$ ad that the aggregation of solid particles contributed to the dependence on SSR. The results shown in Table III.3, however, indicate that sorption was still higher in Column I and II than that in the $333 \mathrm{~g} / \mathrm{L}$ batch system, even though the solid particles are more tightly packed in the columns. This indicates that surface aggregation only partially reduces sorption. As previously described, these flow-through column systems maintain high SSR at the local environment, but with chemistry of the flow-through system that is closer to the $95 \mathrm{~g} / \mathrm{L}$ batch system than to the $333 \mathrm{~g} / \mathrm{L}$ system. 
Table III.3. Comparison of $\mathrm{pH} 9.4$ adsorption results of the flow-through columns with the batch systems.

\begin{tabular}{|cc|c|}
\hline Comparison of Kd & $\mathrm{Kd}(\mathrm{mL} / \mathrm{g})$ & std dev \\
\hline batch system, initial U(VI) conc $=\sim 1 \mathrm{uM}$ & & \\
\hline $333 \mathrm{~g} / \mathrm{L}$ & 0.231 & 0.085 \\
$182 \mathrm{~g} / \mathrm{L}$ & 0.333 & 0.178 \\
$95 \mathrm{~g} / \mathrm{L}$ & 0.804 & 0.106 \\
\cline { 1 - 2 } flow-through column, initial U(VI) conc $=\sim 1 \mathrm{uM}$ & \\
Column I (94 g/L) & 0.444 & \\
Column II (100 g/L) & 0.340 & \\
\hline
\end{tabular}

Even though the solid samples in all the batch systems and for the flow-through columns were pre-equilibrated by the same U(VI)-free stock solutions to reach similar chemical conditions $\left(\mathrm{pH}=9.4, \mathrm{I}=0.05 \mathrm{M}\right.$, saturated with atm. $\mathrm{CO}_{2}$ and calcite solids), differences in system chemistry are likely to have existed in the aqueous and surface environments for samples at different SSR. This is because the sediment solids need a long time to reach equilibration with solution and are likely to continue to release cations/anions into the solution phase during the experimental period, by dissolution of minerals and ion exchange. Because some cationic species such as $\mathrm{Mg}^{2+}, \mathrm{Fe}^{3+}, \mathrm{Al}^{3+}$ adsorb very strongly to clay minerals at high $\mathrm{pH}$, competition for complexation sites by these multi-valent cations could reduce U(VI) sorption. Table III.4 shows the total content of some cations in the batch solutions of the $95 \mathrm{~g} / \mathrm{L}$ and $333 \mathrm{~g} / \mathrm{L}$ systems. $\mathrm{Ca}^{2+}$ contents in all systems were almost the same. This was due to the fact that all the systems were pre-equilibrated with calcite-saturated stock solution, and the U(VI)-laden reaction solution was also saturated with calcite, so that $\mathrm{Ca}^{2+}$ concentrations in these systems were all around the level of the saturation concentration (calculated to be $0.40 \mathrm{ppm}$ ). However, it was apparent that the high SSR system had more $\mathrm{Fe}^{3+}$, and especially $\mathrm{Mg}^{2+}$. It is therefore possible that competition by these cations could contribute to the reduction of $\mathrm{U}(\mathrm{VI})$ sorption. This is especially likely at high $\mathrm{pH}$, because $\mathrm{U}(\mathrm{VI})$ sorption at higher $\mathrm{pH}$ was very weak, and the sorption of these multi-valent cations at high $\mathrm{pH}$ was typically very strong. Therefore, even though the effects of sorption competition by these cations might not be important at lower $\mathrm{pH}$ values (such as $\mathrm{pH} 8.0$ and 8.4), at $\mathrm{pH} 9.4$, such competition could have more important impact on U(VI) sorption. The extent of such competition, however, is yet to be studied and a comprehensive knowledge of the solution chemistry and quantitative complexation results are needed in order to evaluate the extent of sorption reduction for U(VI).

A possible cause of sorption irreversibility could be that $\mathrm{U}(\mathrm{VI})$ minerals such as uranophane $\left\{\mathrm{Ca}\left[\mathrm{UO}_{2}\left(\mathrm{SiO}_{3} \mathrm{OH}\right)\right]\left(\mathrm{H}_{2} \mathrm{O}\right)_{5}\right\}$ or Na-boltwoodite $\left\{\mathrm{Na}\left[\mathrm{UO}_{2}\left(\mathrm{SiO}_{3} \mathrm{OH}\right)\right]\left(\mathrm{H}_{2} \mathrm{O}\right)_{1.5}\right\}$ might form as (surface)precipitates. By doing speciation modeling for U(VI) (data not shown here), the solubility of total U(VI) is $16.5 \times 10^{-3}$ mole/L at $\mathrm{pH} 9.4$ under the bulk solution chemistry of the $95 \mathrm{~g} / \mathrm{L}$ batch system. No U(VI) solids were predicted to form. However, (surface)precipitation might still exist in nearsurface environments and in intra-granular pore regions, where the chemical species could be much more concentrated than in the bulk. Such (surface)precipitation could confine the mobility of $\mathrm{U}(\mathrm{VI})$ and prevent the release of $\mathrm{U}(\mathrm{VI})$ in the desorption process (Liu et al., 2004; Liu et al., In press; McKinley et al., 1995). This could be the cause of 
the strong irreversibility of sorption for the $95 \mathrm{~g} / \mathrm{L}$ system. However, it is not clear as to why a similar extent of irreversibility are not observed in the $333 \mathrm{~g} / \mathrm{L}$ solution.

Table III.4 Cation species in the solution of the batch sorption systems. B/D: below detection limit.

\begin{tabular}{|l|cc|cc|}
\hline & \multicolumn{2}{|c|}{$333 \mathrm{~g} / \mathrm{L}$ batch system } & \multicolumn{2}{c|}{$95 \mathrm{~g} / \mathrm{L}$ batch system } \\
& initial $U$ conc.=1uM & initial $U$ conc.=7.5 uM & initial U conc.=1 uM & initial U conc.=7.5 uM \\
\hline $\mathrm{Mg}(\mathrm{ppm}, \mathrm{ICP}-\mathrm{MS})$ & 2.20 & 2.08 & 1.33 & 1.22 \\
$\mathrm{Ca}$ (ppm, AAS) & 0.41 & -- & 0.39 & -- \\
$\mathrm{Fe}(\mathrm{ppm}, \mathrm{ICP}-\mathrm{MS})$ & 0.06 & $\mathrm{~B} / \mathrm{D}$ & $\mathrm{B} / \mathrm{D}$ & $\mathrm{B} / \mathrm{D}$ \\
\hline
\end{tabular}

\section{Conclusions}

In this work, the sorption behavior of U(VI) to the HSC silt/clay fraction at high $\mathrm{pH}(9.4 \pm 0.1)$ was studied. Results showed that U(VI) sorption at $\mathrm{pH} 9.4$ was much less compared to the sorption at $\mathrm{pH} 8.0$ or 8.4 . Such weak sorption was sensitive to solid-tosolution ratio (SSR). While at lower $\mathrm{pH}, \mathrm{U}(\mathrm{VI})$ sorption was mostly reversible and showed no dependence on SSR, at high $\mathrm{pH}, \mathrm{U}(\mathrm{VI})$ sorption was strongly dependent on SSR with greater sorption at lower SSR (i.e. lower solid particle concentration). In addition, $\mathrm{U}(\mathrm{VI})$ sorption was more irreversible at high $\mathrm{pH}$, and the irreversibility was also stronger at low SSR. Physical mechanisms were explored and it was found that (A) colloidal effects, i.e. retention of $\mathrm{U}(\mathrm{VI})$ by clay colloids in the solution phase were not the cause of this dependence; (B) particle aggregation may have contributed to the reduction of U(VI), probably due to the blocking of surface sites when SSR was high; however, such aggregation could not account for the full magnitude of observed effects. Possible chemical mechanisms were discussed. Multi-valent cations, especially $\mathrm{Mg}^{2+}$, were found to be more concentrated in the high SSR systems. This possibly caused competition for sorptive sites with U(VI) and suppressed U(VI) uptake. In addition, although U(VI) mineral precipitation was not confirmed by HYDRAQL models using bulk solution chemistry, it is possible that some unaccounted (surface)precipitates were formed in surface chemical environments. Such (surface)precipitation might deposit U(VI) in intragranular pores, and could lead to irreversibility of the desorption process.

Future work is being planned to further investigate these possibilities. Ideally, such work should include spectroscopic studies to confirm the existence of and identify solution- and surface-phase species.

\section{Environmental Implications}

This work demonstrates that the solid-to-solution ratio (SSR) is a potentially important factor governing U(VI) sorption in the HSC silt/clay material at high $\mathrm{pH}$ (>8.5). Such high $\mathrm{pH}$ conditions do exist in the U(VI) contaminated locations at Hanford Site, where the groundwater $\mathrm{pH}$ was initially elevated by the strong alkaline plumes leaked from storage tanks and where the sediment composition is similar to the HSC materials being studied in this effort. For such conditions, U(VI) sorption can have strong dependence on SSR and sorption reversibility can be affected. Therefore, U(VI) sorption behavior in the porous media can be very different from that observed in batch systems where SSR is much lower. Therefore, the application of batch-obtained U(VI) sorption 
characteristics to field conditions should be undertaken with caution, with due consideration of these likely differences. 


\section{Part IV. Experimental and Modeling Study of Retarded U(VI) Diffusion in Hanford Silt/Clay Material}

\section{Introduction}

$\mathrm{U}(\mathrm{VI})$ use in the nuclear energy cycle, weapons processing, and interim storage and disposal practices has resulted in the contamination at many DOE sites. Understanding U(VI) transport in the subsurface sediments at these sites is critical for risk assessment and remediation efforts. While large-scale $U$ migration along permeable pathways in the subsurface is generally determined by advections, long-term or local scale transport in effectively impermeable regions, such as rock matrices or clays, is controlled principally by diffusion (Arnold et al., 2003; Muurinen, 1990; Tokunaga et al., 2004). Diffusion can occur in the pore networks surrounding particle grains as interparticle diffusion and in intra-granular regions as intra-particle diffusion. Grain-scale diffusion has been observed to control the release of desorbed and/or dissolved U(VI) from sediment materials from the DOE Hanford site (4-7) and larger-scale (inter-particle) diffusion will be the primary source of transport into and out of larger-scale permeable zones(Liu et al., 2004; Liu et al., In press; McKinley et al., 1995). Whether such interparticle diffusion is also affected by intra-granular effects is an open question that remains to be resolved.

To accurately predict U(VI) diffusive transport, it is prerequisite to know the effective diffusion coefficient $\left(D_{e}\right)$ of the various $U(V I)$ species, which is determined by both the tortuous nature of the pore network and by characteristics of the molecular U(VI) species such as size and charge (Grathwohl, 1998). In many modeling predictions, including predictions of U(VI) diffusion in Hanford materials, theoretical values of molecular diffusion coefficients $\left(\mathrm{D}_{0}\right)$ for $\mathrm{U}(\mathrm{VI})$ species were used to calculate $\mathrm{D}_{\mathrm{e}}(\mathrm{Li}$ and Gregory, 1974; Millard and Hedges, 1996; Tokunaga et al., 2004; Yamaguchi and Nakayama, 1998; Yamaguchi et al., 1997). However, it is critical to independently evaluate these values by doing diffusion experiments, and so far such work has been very few. In addition, among available experimental studies of U(VI) diffusion, very few were conducted under carefully controlled chemical conditions. This increases the uncertainty in the diffusion coefficient values obtained from these works, because U(VI) speciation is strongly dependent on the chemical conditions (Bernhard et al., 1996; Bernhard et al., 2001; Chisholm-Brause et al., 2001; Davis et al., 2002; Dong et al., 2005; Kohler et al., 1996), and thus $D_{0}$ and $D_{e}$ values can vary greatly in different chemical environments and with different porous media (Tokunaga et al., 2004; Yamaguchi and Nakayama, 1998; Yamaguchi et al., 1997).

U(VI) diffusion in porous sediment media is always found to be coupled with sorption/desorption to/from the solid phase(Arai et al., 2006; Barnett et al., 2002; Davis, 2001; Davis et al., 1998; Davis et al., 2004). Such processes retard the mobility of U(VI) in the porous sediments. In many U(VI) transport studies, these retardation processes are assumed to maintain sorption/desorption equilibrium in the local environments (Kohler et al., 1996; Muurinen, 1990). Such local equilibrium is assumed to be governed by sorption isotherms, which can be independently obtained by conducting batch sorption experiments. However, U(VI) sorption to sediment materials from Hanford sites has been 
frequently discovered to have kinetic controls by rate-limiting processes such as intraparticle diffusion (Liu et al., 2004; Liu et al., In press; McKinley et al., 1995). If such kinetic processes are sufficiently slow, the local equilibrium assumption (LEA) cannot be applied to model U(VI) migration. Despite of such findings, in the case of inter-particle diffusion-dominated U(VI) transport, the LEA may still be valid due to the fact that interparticle diffusion is usually a slow process and the diffusion time scale can be much longer than the time scale of the kinetic processes.

In this project, we conducted diffusion cell experiments using the silt/clay fraction of the Hanford Silt Composite (HSC, RCRA borehole \# 299-W22-48) (Serne et al., 2002) and its silt/clay fraction to study U(VI) diffusion when it was coupled with sorptive retardation. Chemical conditions were strictly controlled and were designed to simulate the calcareous and alkaline subsurface environment of the sampling aquifer. Special diffusion cell designs and experimental methods were developed so that the LEA assumption could be tested. As we discussed under hypothesis (4) in "Project Objectives and Hypotheses", we proposed that sorption local equilibrium could be assumed in the case of diffusion-dominated transport, and inter-particle diffusion coupled with equilibrium sorption governed by independently obtained batch sorption isotherms could fully describe the sorption-retarded diffusive transport of U(VI) in the HSC silt/clay material. Based on this, a U(VI) transport model was developed to obtain both effective and molecular diffusion coefficients of $\mathrm{U}(\mathrm{VI})$. These efforts will provide insight to the characteristics of $\mathrm{U}(\mathrm{VI})$ retarded diffusion in similar sediments from Hanford. U(VI) diffusion coefficients values obtained by us can work as references in the modeling of $\mathrm{U}(\mathrm{VI})$ fate and transport in the subsurface of Hanford.

\section{Materials and Methods}

\subsection{Materials and Measurements}

The HSC silt/clay material was used in the U(VI) diffusion studies. Characterization of the material is given in Part I of this report. U(VI) diffusion study was performed at $\mathrm{pH} 8.0( \pm 0.1)$ and $\mathrm{I}=0.02 \mathrm{M}$. This $\mathrm{pH}$ was chosen because that the $\mathrm{pH}$ value of the pore water in the sampling borehole is between 7.0 and 8.0, and the equilibration solution was found to be alkaline with pH of about 9.0. (Refer to Table I.2 of Part I.) A $\mathrm{U}(\mathrm{VI})$-free stock solution was prepared at $\mathrm{pH} 8.0( \pm 0.1)$, buffered by $\mathrm{Na}_{2} \mathrm{CO}_{3}-\mathrm{NaHCO}_{3}$ and adjusted by $\mathrm{HNO}_{3} / \mathrm{NaOH}$. Ionic strength was maintained at $0.02 \mathrm{M}$ using $\mathrm{NaNO}_{3}$ as support electrolyte. The stock solution was saturated with atmospheric $\mathrm{CO}_{2}\left(\mathrm{P}_{\mathrm{CO} 2}=10^{-}\right.$ $3.5 \mathrm{~atm}$ ) and with calcite powders. The solution was used for pre-equilibration of the solid and for making of $\mathrm{U}(\mathrm{VI})$-laden solutions in all following experiments. Uranyl nitrate $\left(\mathrm{UO}_{2}\left(\mathrm{NO}_{3}\right)_{2}\right)$ was used to make concentrated U(VI) stock solutions of $10^{-3}-10^{-2}$ mole/L. The U(VI)-laden reaction solution in the batch and diffusion experiments was prepared by spiking a small amount of the concentrated $\mathrm{U}(\mathrm{VI})$ solution to the $\mathrm{U}(\mathrm{VI})$-free stock solution. All U(VI) concentrations were measured by a Kinetic Phosphorescence Analyzer (KPA-11, ChemChek Instr., Richland, WA), which had an effective detection limit of $0.1 \times 10^{-6} \mathrm{~g} / \mathrm{L}(\mathrm{ppb})$. Concentration of tritiated water (HTO) was measured by a Liquid Scintillation Counter (Model 3801, Beckman Instr., Fullerton, CA). 


\subsection{Batch Kinetics and Isotherm Experiments}

Batch sorption/desorption kinetics study was preformed on the HSC silt/clay samples. Initial U(VI) concentrations of $1.00 \times 10^{-6} \mathrm{~mole} / \mathrm{L}$ and $0.24 \times 10^{-6} \mathrm{~mole} / \mathrm{L}$ were used for the sorption stage. $2.5 \mathrm{~g}$ of the solid $(\mathrm{n}=2)$ was added to a $50 \mathrm{~mL}$ polypropylene centrifuge tube and was pre-equilibrated by $25 \mathrm{~mL}$ of the $\mathrm{pH} 8.0( \pm 0.1) \mathrm{U}(\mathrm{VI})$-free stock solution for 4 times, each lasting 3 days. U(VI) washed off by each equilibration was measured. After the $4^{\text {th }}$ pre-equilibration wash, the background labile U(VI) left in the solid phase was assumed to be at equilibrium with the U(VI) in the $4^{\text {th }}$ wash solution. This amount was calculated by iterations in the calculation of the sorption isotherm. Calculation details are given in Section 4, "Results and Discussion". After preequilibration, the washing solution was decanted and $25 \mathrm{~mL}$ the U(VI)-laden solution was added to the solids. The sorption lasted 4 days and $10 \mathrm{uL}-50 \mathrm{uL}$ of solution was taken after $0,2,4,6,10,22,50,72$, and 96 hours for measurement of U(VI) concentration. After 96 hours, the samples were centrifuged and the supernatant was decanted. Then, $25 \mathrm{~mL} \mathrm{U}(\mathrm{VI})$-free stock solution was added to the solids in each tube to study desorption kinetics. Again, the solution was sampled for U(VI) concentration measurement after 0 , $4,18,45,72$, and 144 hours. The sample tubes were rotated by a rotation shaker for all experiments and the temperature was controlled at $22.5^{\circ} \mathrm{C}$.

Batch isotherm experiments were also performed on the HSC silt/clay. Preliminary studies showed that (VI) sorption at this $\mathrm{pH}$ was independent of solid/solution ratio (data not shown here). So the sorption/desorption isotherm experiments were conducted at a solid/solution ratio of $95 \mathrm{~g} / \mathrm{L} .0 .5 \mathrm{~g}$ HSC silt/clay was added to a $5 \mathrm{~mL}$ centrifuge tube. Similar to the kinetics studies, all samples were preequilibrated by washing the solids in U(VI)-free stock solutions for 4 times using a solid/solution ratio of $100 \mathrm{~g} / \mathrm{L}$. After pre-equilibration, the batch system was centrifuged and the washing solution was decanted. Then $5 \mathrm{~mL}$ of the U(VI)-laden reaction solution was added to each centrifuge tube, with $\mathrm{U}(\mathrm{VI})$ concentrations ranging from $\sim 1 \times 10^{-7}$ to $\sim 2.5 \times 10^{-5} \mathrm{~mole} / \mathrm{L}$. Triplicate samples were used for each concentration. 3 days of reaction time was adopted. After the sorption stage, the samples were centrifuged and the supernatant was decanted and measured for U(VI) concentration. Then $5 \mathrm{~mL}$ U(VI)-free stock solution was added to the solids in each batch reaction tube for the desorption of sorbed U(VI). 10uL-50uL of solution was taken from the samples after 3 days and 6 days respectively to measure desorbed $\mathrm{U}(\mathrm{VI})$ in the solution phase and obtain the desorption isotherm.

\subsection{Sequential Extraction}

In order to independently determine the sorbed U(VI) in the solid, a sequential extraction method was designed. This method was later applied in the diffusion cell experiments to obtain the solid phase U(VI) profile along the cell length. A sequence of extractions by U(VI)-free carbonate-bicarbonate solutions with increasing $\mathrm{pH}$ were performed in the following order: $\mathrm{pH} 8.0$ extraction $-\mathrm{pH} 9.5$ extraction- $-\mathrm{pH} 9.5$ extraction $-\mathrm{pH} 10.0$ extraction, each lasting for 6 days. This procedure was designed due to the fact that $\mathrm{U}(\mathrm{VI})$ sorbs less at higher $\mathrm{pH}$, and is almost non-sorbing at $\mathrm{pH} 10.0$. However, $\mathrm{pH} 10.0$ extraction was not applied directly as the first step. This was out of the consideration that the diffusion experiments were performed at $\mathrm{pH} 8.0( \pm 0.1)$, where lots 
of carbonate minerals were dissolved, and that increasing the $\mathrm{pH}$ immediately to a high value might cause precipitation of such minerals and the co-precipitation of desorbed $\mathrm{U}(\mathrm{VI})$ with them, so that the sorbed U(VI) would not be sufficiently extracted.

To test the extraction efficiency of this method, the batch sorption/desorption samples (from Section 2.2) were used. The 6-day desorption of U(VI) in the sorption/desorption study was taken as the first extraction step, then the other extractions were performed in due order. Extracted U(VI) was measured after each extraction. Total extracted U(VI) from was compared with the estimated total sorbed U(VI), which could be obtained by mass balance calculations.

\subsection{Diffusion Cell Experiments}

U(VI) diffusion experiments were performed by applying two types of diffusion cell designs. Figure IV.1 shows the design of Type I cell. Figure IV.2 shows the design of Type II cell. Both design types had a Cell Chamber which was a $4 \mathrm{~cm}$ long, $2.54 \mathrm{~cm}$ (1") ID acrylic cylinder. The sediment material was evenly divided in to 16 portions by a 16-Way Spinning Riffler (Gilson Company Inc., Worthington, OH). The cell column was then packed in lofts using these portions, each of which was pressed into the column using a flat-top rod that had almost the same diameter as the cell. The packing procedure for each loft was carefully controlled so that all the lofts were condensed to a similar compactness to maintain homogeneity of the entire cell. One diffusion cell was constructed for each design type, and the operation conditions and physical data are listed in Table IV.1.

Saturation and pre-equilibration of sediment materials. Similar to the preequilibration (i.e. pre-washing) procedure for the batch system (see Protocol $\mathrm{C}$ of Appendix II), all the cell sediments was pre-washed by the U(VI)-free stock solution (see Section 2.1). In each pre-equilibration, the mass ratio of the cell sediments to the stock solution was also the same $(100 \mathrm{~g} / \mathrm{L})$ as that of the batch systems. Figure IV.3 is a photo of the pre-equilibration set-up of the diffusion cell. To perform the pre-equilibration wash, the sediment-filled Cell Chamber was first connected to two Dispersion Chambers on both ends. Each Dispersion Chamber was separated from the Cell Chamber by a 0.4um membrane and a stainless steel screens as support for the membrane. The Dispersion Chambers were filled with $1 \mathrm{~mm}$ diameter non-reactive borosilicate glass beads to disperse the inflow solution. Before the first pre-equilibration wash, pure $\mathrm{CO}_{2}$ gas was flushed into the cell to replace air in the pores of the dry sediment material. After all air was repelled, the U(VI)-free stock solution was pumped through the cell column to dissolve $\mathrm{CO}_{2}$. When all $\mathrm{CO}_{2}$ gas was dissolved, all pore space was occupied by solution and the sediment was totally saturated. During each wash, the stock solution was circulated through the cell column for long enough so that constant $\mathrm{pH}$ values and U(VI) concentrations in the washing solution were reached. Then the solution was replaced by fresh stock solution for the next pre-equilibration wash. A total of four pre-equilibration washes were applied, with the flow-through pore volumes of the stock solution for each washing listed in Table IV.1. When the pre-equilibration was completed, the Cell Chamber was disconnected from the Dispersion Chambers, and the change in the weight of the Cell Chamber was measured and was taken as the pore water weight. By knowing 
this weight and assuming water density of $1.0 \mathrm{~g} / \mathrm{mL}$ at $22.5^{\circ} \mathrm{C}$, the porosity of the diffusion cell was calculated.

Diffusion phase. After the $4^{\text {th }}$ pre-equilibration wash, for Type I cell, the Cell Chamber was connected to two acrylic end caps at both ends to hold the $0.4 \mu \mathrm{m}$ membranes and stainless steel screens in place (see Figure IV.1). Each cap had a $2.54 \mathrm{~cm}$ hole in the middle to allow the cell sediment to be accessible (separated by $0.4 \mu \mathrm{m}$ membranes) over the entire cross-sectional area. Then the cell device was horizontally submerged in a $4.78 \mathrm{~L}$ polypropylene tank filled with $4.5 \mathrm{~L} \mathrm{U}(\mathrm{VI})$-laden stock solution. During the diffusion phase, U(VI) diffused into the cell sediment from both ends of the cell through the membranes. The volume of the tank was large enough so that U(VI) concentration change in the tank was less than $3 \%$ and was considered negligible. The tank was placed on top of a magnetic stirrer and the solution in the tank was stirred by a stir bar. U(VI) concentration was monitored during the diffusion phase by taking out $10 \mathrm{uL}$ of solution frequently from the tank.

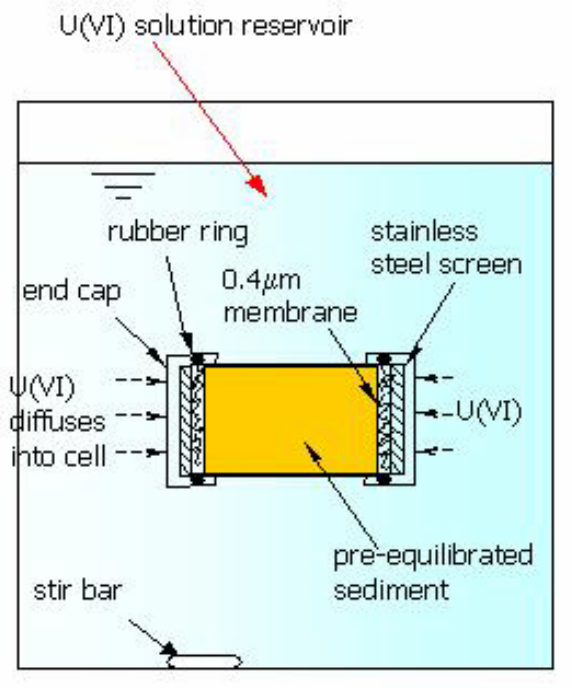

Figure IV.1 Illustration of diffusion cell Type I design.

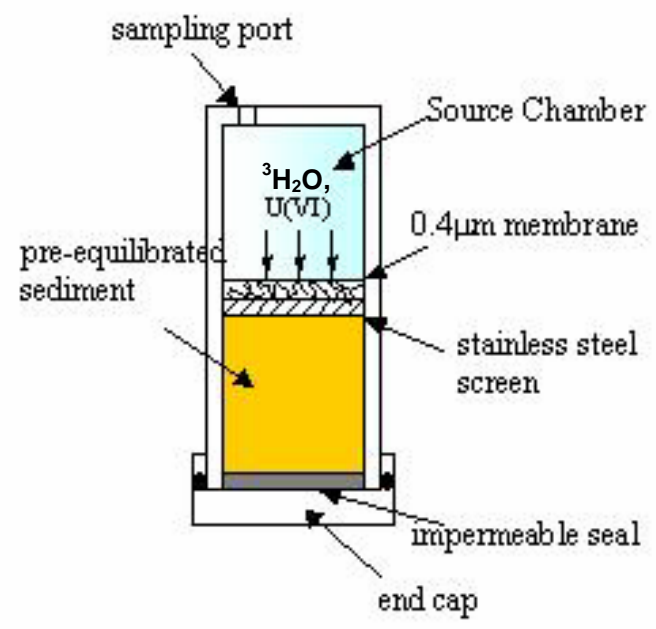

Figure IV.2 Illustration of diffusion cell Type II design.

For Type II cell, the Cell Chamber was connected to a $3 \mathrm{~cm}$ long, $2.54 \mathrm{~cm}$ ID Source Chamber on one end and a dead End Cap on the other. Figure IV.4 is a photo of the assembled Type II cell. U(VI)-laden stock solution was slowly injected into the Source Chamber by using a syringe and a thin rubber tubing. The volume of the injected $\mathrm{U}(\mathrm{VI})$ solution was calculated by the weight change in the device before and after the injection. The stock solution was also spiked with tritiated water (HTO) tracer. A small magnetic stir bar was hang in the middle of the solution from the top by a Tyflon string, and the cell device was placed on a magnetic stirrer to very gently stir the solution so that complete mixing was ensured without incurring advective flux into the cell sediment. After the diffusion phase was started, U(VI) and HTO concentrations in the Source Chamber were measured at different diffusion times by taking out $10 \mathrm{uL}$ of the solution 
from the sampling port for each measurement. Total change in the source solution volume was controlled to be less than $3 \%$.

Cell Sectioning and extraction of solid phase U(VI). For both of the diffusion cells constructed, at the finish of the diffusion phase, the cell sediment was extruded out by an acrylic rod and was sectioned into 13 to 14 2-3mm thick slices. Each slice was measured for it thickness at 3-4 different locations around the perimeter and the average thickness was adopted. Each slice was divided into three parts and one part $(\sim 1 \mathrm{~g})$ was centrifuged at 25,000 $\mathrm{rcf}$ and $\mathrm{T}=22.5^{\circ} \mathrm{C}$ for 10 minutes (Centrifuge 5417R, Eppendorf, Hamburg, Germany). By doing this, a fraction of the pore water was separated from the solid phase due to the higher solid compactness achieved by the centrifugation and $10 \mu \mathrm{L}$ of the pore water was taken out for measurement of U(VI). The other two parts of each slice was each placed in a $5 \mathrm{~mL}$ centrifuge vial as duplicate samples for extraction of solid phase U(VI). The weight of these two parts of the slices was calculated by the differencing the weights of the vials before and after the loading of the sediments. The volume of pore water contained in these two parts was calculated by using the porosity of the cell. The sequential extraction method was then used on these samples. For the slices of cell SC II, 6 days were used for each extraction step of the sequential extraction. For SC I, $2 \sim 4$ weeks were used as extraction time for each step. Total U(VI) extracted (including U(VI) in the solid phase and in pore water) from the solids was calculated and the pore water $\mathrm{U}(\mathrm{VI})$ was subtracted from the total to obtain the extracted solid phase U(VI).

Table IV.1 Diffusion cell columns and operation data.

\begin{tabular}{|l|c|c|}
\hline Cell name & SCI & SCII \\
\hline Material & HSC silt/clay & HSC silt/clay \\
\hline Cell design type & Type I & Type II \\
\hline Bulk solid density & 1.4806 & 1.5484 \\
\hline Porosity & 0.446 & 0.440 \\
\hline $\begin{array}{l}\text { Flow-through pore volumes in the } 1^{\text {st }}, 2^{\text {nd }} \\
3^{\text {rd }} \text { and } 4^{\text {th }} \text { pre-equilibration washing }\end{array}$ & $275,155,199,354$ & $133,166,126,126$ \\
\hline Diffusion time & 918.5 hours & 785.5 hours \\
\hline
\end{tabular}




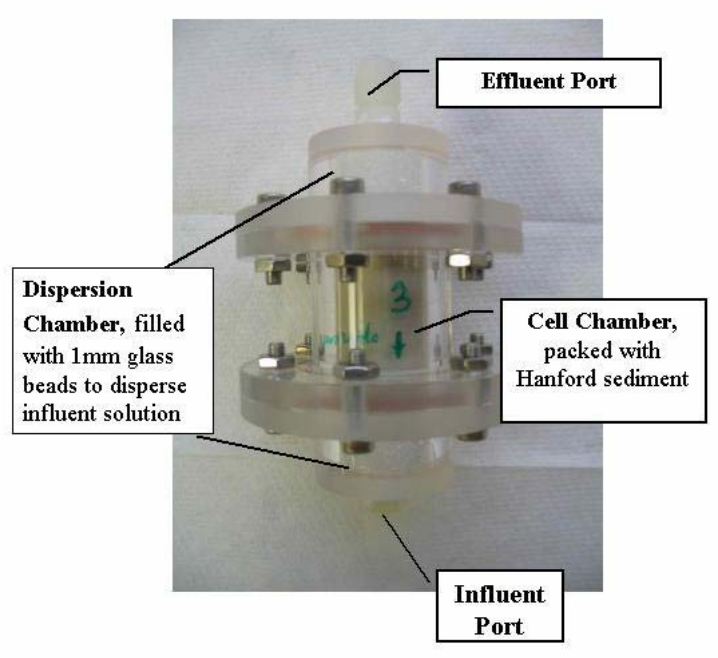

Figure IV.3. Photo of diffusion cell SCII assembled for pre-equilibration wash.

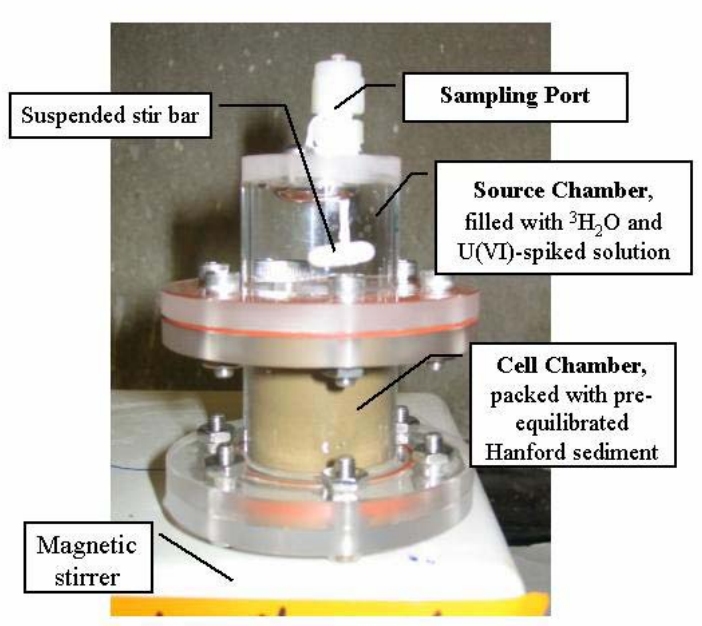

Figure IV.4. Photo of diffusion cell SCII (Type II cell) during the diffusion phase.

\section{Modeling of U(VI) Diffusion}

U(VI) diffusion in the diffusion cell sediment was retarded by its sorption to the sediment solids. The retarded diffusive transport was modeled by Equation IV.1.

$$
\varepsilon \frac{\partial C}{\partial t}+(1-\varepsilon) \rho_{s} \frac{\partial S}{\partial t}=\varepsilon D_{e} \frac{\partial^{2} C}{\partial x^{2}}
$$

$\mathrm{C}$ is the concentration of $\mathrm{U}(\mathrm{VI})$ in pore water. $\mathrm{S}$ is $\mathrm{U}(\mathrm{VI})$ concentration in the solid phase per unit mass of the solid. $\rho_{\mathrm{s}}$ is the density of the solid phase in the compact (non-porous) form. $\varepsilon$ is the porosity of the medium. $\mathrm{D}_{\mathrm{e}}$ is the effective diffusion coefficient of $\mathrm{U}(\mathrm{VI})$ in the porous medium. Here $\mathrm{D}_{\mathrm{e}}$ is defined as:

$$
D_{e}=\frac{D_{0} \delta}{\tau_{f}}
$$

$\delta$ is the dimensionless constrictivity which accounts for the geometric hindrance and can be related to the ratio of the size of the diffusion species to the size of the pores (Ball and Roberts, 1991; Cussler, 1997). When the size of the diffusing molecule/ion is small compared with the pore size, the geometric constriction can be neglected and $\delta$ is approximated to unity (Grathwohl, 1998).

To test the local equilibrium assumption (LEA) proposed in this report, we first assumed that $\mathrm{U}(\mathrm{VI})$ in the pore water and the solid phase of the cell were always at equilibrium, governed by the batch sorption isotherm $\left(\mathrm{S}=\mathrm{K}_{\mathrm{f}} \mathrm{C}^{\mathrm{n}}\right.$ for Freundlich isotherm, $\mathrm{K}_{\mathrm{f}}$ and $\mathrm{n}$ are parameters to be determined by the batch experiments). With this assumption, the transport equation becomes Equation IV.3. Equation IV.4 and IV.5 are the boundary conditions for cell of Type I and Type II, respectively. $\mathrm{C}_{\text {chamber }}$ is the U(VI) concentration in the Source Chamber of Type II cell, and $\mathrm{V}_{\text {chamber }}$ is the volume of the Source Chamber. A is the cross-sectional area of the cell column. 


$$
\begin{aligned}
& \left(1+\frac{(1-\varepsilon)}{\varepsilon} \rho_{s} K_{f} C^{n-1}\right) \frac{\partial C}{\partial t}=D_{e} \frac{\partial^{2} C}{\partial x^{2}} \\
& \mathrm{C}_{\mathrm{x}=0}=\mathrm{C}_{0}=\text { constant } \\
& \frac{\partial C_{\text {chamber }}}{\partial t} V_{\text {chamber }}=A \varepsilon\left(-\left.D_{e} \frac{\partial C}{\partial x}\right|_{x=0}\right)
\end{aligned}
$$

The transport equations were solved numerically using the finite difference method (explicit in time). For cell SC I, experimental data of the pore water and solid phase U(VI) concentrations were used for the fitting of $\mathrm{D}_{\mathrm{e}}$ value. For cell SC II, the timevariant concentrations of $\mathrm{HTO}$ and $\mathrm{U}(\mathrm{VI})$ in the were used to fit for $\mathrm{D}_{\mathrm{e}, \mathrm{HTO}}$ and $\mathrm{D}_{\mathrm{e}, \mathrm{U}(\mathrm{VI}) \text {, }}$ respectively. Then the transport model using the fitted $\mathrm{D}_{\mathrm{e}, \mathrm{U}(\mathrm{VI})}$ value was used to predict the spatial distribution of U(VI) in both cell pore water and solid phase to compared with experimental data. Fitting of the parameters was achieved by using the MarquadtLevenberg non-linear least square method (Optimization Toolbox, Matlab), so that the sum of the squares of the differences between the modeling results and the experimental data was minimized.

\section{Results and Discussion}

\subsection{Batch Sorption/Desorption Kinetics}

Results of sorption/desorption kinetics for HSC silt/clay at $\mathrm{pH} 8.0( \pm 0.1)$ are shown in Figure IV.5. Figure IV.5(a) shows that the sorption process had a fast initial stage and later a slow approach toward equilibrium. For the $1.00 \times 10^{-6} \mathrm{M}$ system, equilibrium was reached in $\sim 50$ hours and the concentrations at $50^{\text {th }}, 72^{\text {nd }}$ and $96^{\text {th }}$ hour were statistically at the same level. For the $0.24 \times 10^{-6} \mathrm{M}$ system, it was less obvious to prediction the time to reach equilibrium since the data at the $50^{\text {th }}$ hour were higher than the $24^{\text {th }}$ hour data, and the $72^{\text {nd }}$ hour and $96^{\text {th }}$ hour data were statistically the same. Therefore, for the $0.24 \times 10^{-6} \mathrm{M}$ system, we estimated that equilibrium was reached between 50 and 72 hours.
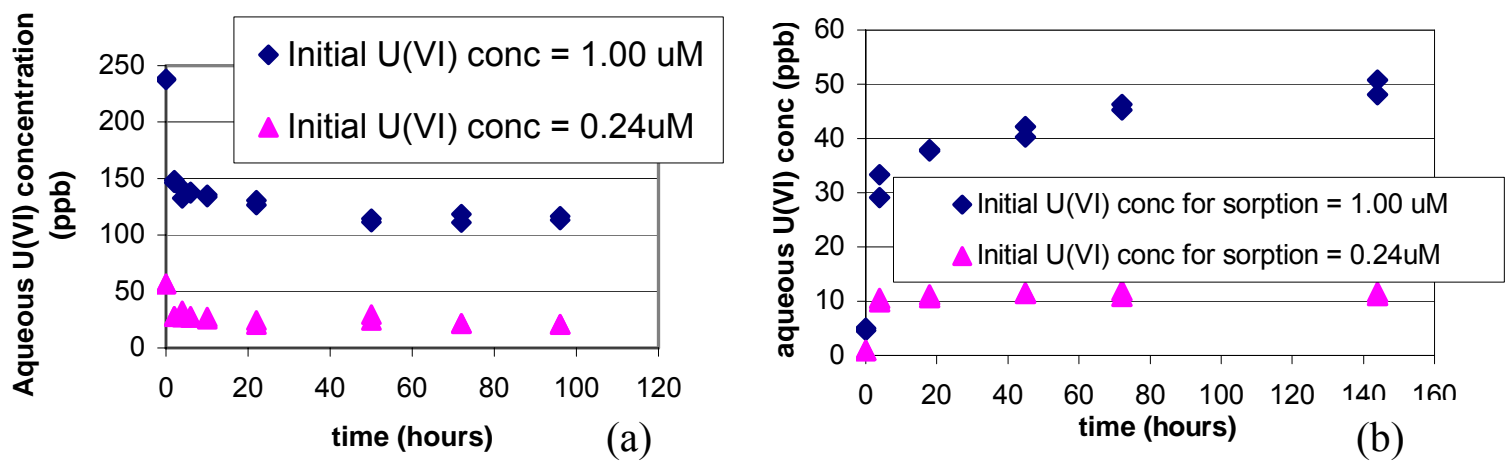

Figure IV.5 (a) $\mathrm{U}(\mathrm{VI})$ sorption kinetics on Hanford silt/clay fraction at $\mathrm{pH}=8.0( \pm 0.1)$. Initial $\mathrm{U}(\mathrm{VI})$ concentration of $1.00 \times 10^{-6} \mathrm{M}$ and $0.24 \times 10^{-6} \mathrm{M}$, solid/solution $=100 \mathrm{~g} / \mathrm{L}, \mathrm{I}=0.02 \mathrm{M}, \mathrm{P}_{\mathrm{CO} 2}=10^{-3.5}$ atm, $\mathrm{T}=22.5^{\circ} \mathrm{C}$. (b) $\mathrm{U}(\mathrm{VI})$ desorption after sorption equilibrium is reached. The same samples from (a) were used. 
Desorption kinetics is shown in Figure IV.5(b). Similar kinetic features were observed for desorption - the releasing process showed a fast initial stage and later a slow stage toward equilibrium. For the desorbing process of the samples using $0.24 \times 10^{-6} \mathrm{M}$ $\mathrm{U}(\mathrm{VI})$ initially, equilibrium was reached in approximately 24 hours. But for the desorbing of the samples using $1.00 \times 10^{-6} \mathrm{M} \mathrm{U}(\mathrm{VI})$ initially in sorption, this process was much more slowly, with equilibrium NOT obtained even after 6 days (144 hours). Such slow kinetics indicated that local sorption equilibrium might not be valid for the retarded diffusive transport of U(VI).

\subsection{Batch Sorption/Desorption Isotherm}

Figure IV.6 shows results of 3-days sorption and 6-day desorption results on the HSC silt/clay fraction. Sorption to the silt/clay sample was found to be slightly irreversible in the 6-day period as the desorption isotherm was found to be above the sorption isotherm but was very close to it. As indicated by the results of the kinetics experiments, 6 days of desorption was not long enough to obtain equilibrium. Therefore, given longer desorption time, we believe more U(VI) could desorb so that the sorption and desorption isotherms would converge in the long run. Therefore, we can expect that sorption of U(VI) under such chemical conditions is mostly reversible or completely reversible, although the desorption process is very slow.

To obtain the batch isotherm, the background labile U(VI) concentration need to be pre-known because of its participation in the sorption/desorption equilibrium. From the results of Part I of this report, we know that the amount of background labile U(VI) depends on the $\mathrm{pH}$. Also, more U(VI) became labile with more times of equilibration of the solids and longer equilibration time. In Part I, the total background labile was determined for sorption at $\mathrm{pH} 9.4( \pm 0.1)$. For the $\mathrm{pH} 8.0( \pm 0.1)$ experiments, the total background labile U(VI) content in the HSC silt/clay sample could be different. Since 4 3-day pre-equilibration washes were applied to both batch and column sediments, we assumed that the fourth wash solution was at equilibrium with the background labile $\mathrm{U}(\mathrm{VI})$ in the solid phase, governed by the batch sorption isotherm which was not yet known. Therefore, we took an interation procedure to obtain both the background labile $\mathrm{U}(\mathrm{VI})$ and the isotherm. We first guessed a labile value to calculate the total labile U(VI) — including background labile and newly sorbed U(VI), using Equation IV.6. Then the isotherm was obtained by regressing the U(IV) concentration in the solution phase and the total labile U(VI) in the solid phase by various types of isotherm models to find a best fitting isotherm. Then, the background labile value was re-evaluated using the isotherm, and the new value was used to calculate a new isotherm. This iteration was repeated until the guessed value of background labile U(VI) and the isotherm-predicted value converged. The isotherm was thus obtained. Table IV.2 shows the results of the final iteration. The background labile U(VI) in the diffusion cell sediments after the $4^{\text {th }}$ pre-equilibration wash was calculated using the U(VI) concentration in the $4^{\text {th }}$ wash solution, using the isotherm obtained in the $5^{\text {th }}$ column of Table IV.2.

$$
S_{T}=\frac{C_{0} V+S_{L} m-C_{e} V}{m}=S_{L}+S_{\text {sorbed }}
$$


$\mathrm{S}_{\mathrm{T}}$ : total labile $\mathrm{U}(\mathrm{VI})$ in the solid phase

$\mathrm{S}_{\mathrm{L}}$ : background labile $\mathrm{U}(\mathrm{VI})$

$\mathrm{S}_{\text {sorbed: }}$ U(VI) sorbed to the solid phase from solution phase 54

$\mathrm{C}_{0}$ : initial $\mathrm{U}(\mathrm{VI})$ concentration in solution

$\mathrm{C}_{\mathrm{e}}$ : $\mathrm{U}(\mathrm{VI})$ concentration in solution at equilibrium

$\mathrm{m}$ : mass of solids in the batch system

$\mathrm{V}$ : volume of solution in the batch system

Freundlich type of isotherm was observed to fit best for both sorption and desorption. Data of the $\mathrm{pH} 8.0$ isotherms are summarized in Table IV.3. Isotherm data for the original HSC obtained in previous work are also listed. The HSC silt/clay sorption isotherm was used in all diffusion cell modeling when LEA was assumed.

Table IV.2 Calculation of isotherm and background labile $\mathrm{U}(\mathrm{VI})$ of the HSC silt/clay sample at $\mathrm{pH}$ 8.0 by iteration. Last iteration data listed. Background labile $U(\mathrm{VI})$ values for the diffusion cell sediments were calculated using the isotherm obtained in the $95 \mathrm{~g} / \mathrm{L}$ bath system.

\begin{tabular}{|l|c|c|c|c|c|c|}
\hline $\begin{array}{c}\text { HSC silt/clay } \\
\text { samples }\end{array}$ & $\begin{array}{c}\text { Leached U(VI) } \\
\text { by 4 pre-eq. } \\
\text { washes } \\
\text { (ngU/g soil) }\end{array}$ & $\begin{array}{c}\mathrm{U}(\mathrm{VI}) \text { conc. in } \\
4^{\text {th }} \text { wash } \\
\text { solution }(\mathrm{ppb})\end{array}$ & $\begin{array}{c}\text { Estimated } \\
\text { bkgd labile } \mathrm{U} \\
\text { remained } \\
\text { after 4th } \\
\text { wash (ng/g) }\end{array}$ & $\begin{array}{c}\text { Sorption isotherm } \\
\text { by est'd bkgd labile } \\
\mathrm{U}\end{array}$ & $\begin{array}{c}\text { Remained bkgd } \\
\text { labile U, } \\
\text { calculated by } \\
\text { isotherm, (ng/g) }\end{array}$ & $\begin{array}{c}\text { Total bkgd } \\
\text { labile U at pH } \\
8.0 \text { (ng/g) }\end{array}$ \\
\hline $95 \mathrm{~g} / \mathrm{L}$ batch & $31.1 \pm 0.1$ & $0.52 \pm 0.04$ & 19.8 & $\mathrm{~S}=32.7417 \mathrm{C}^{0.7710}$ & 19.75 & 50.9 \\
$185 \mathrm{~g} / \mathrm{L}$ batch & $22.5 \pm 3.8$ & $0.71 \pm 0.16$ & -- & as above & 25.14 & 47.6 \\
Cell SCl & 35.4 & 0.55 & -- & as above & 20.53 & 55.9 \\
Cell SCll & 33.8 & 0.51 & -- & as above & 19.48 & 53.3 \\
\hline
\end{tabular}

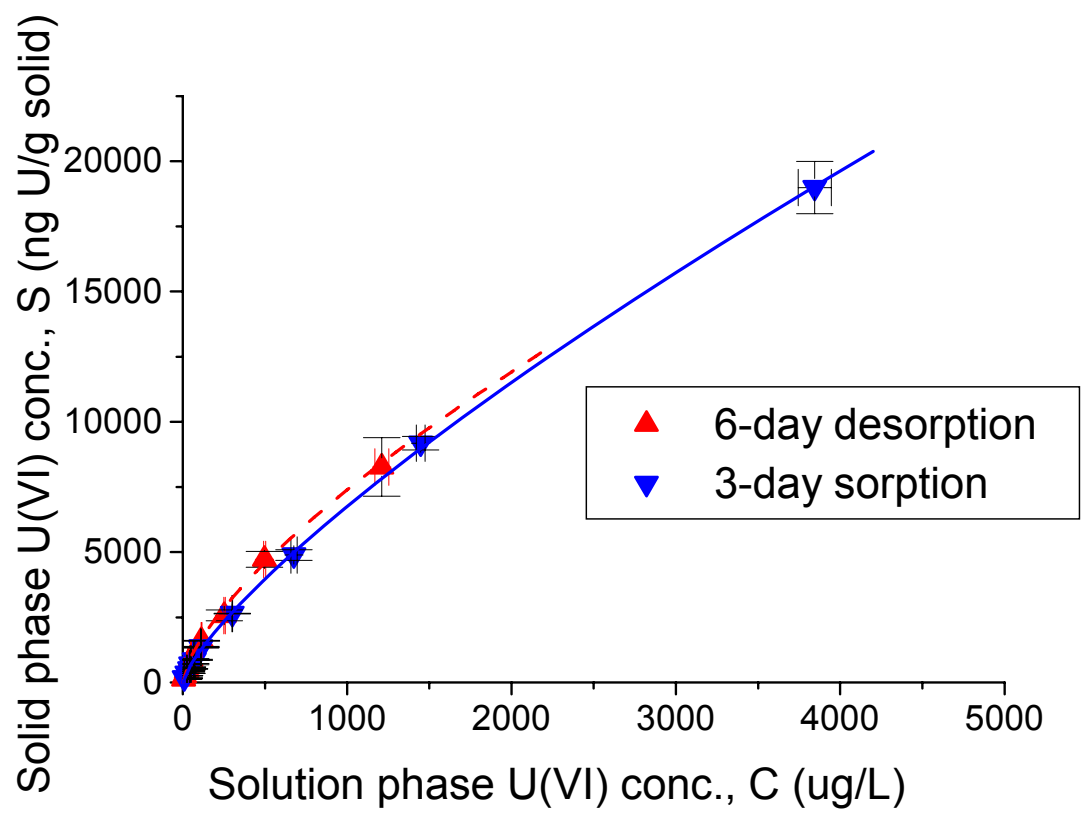

Figure IV.6 $\mathrm{U}(\mathrm{VI})$ sorption and desorption isotherms on HSC silt/clay fraction. Initial $\mathrm{U}(\mathrm{VI})$ concentration of $0.1-25.0 \times 10^{-6} \mathrm{M}$, solid/solution $=95 \mathrm{~g} / \mathrm{L}, \mathrm{I}=0.02 \mathrm{M}\left(\mathrm{NaNO}_{3}\right), \mathrm{pH}=8.0 \pm 0.1$, $\mathrm{P}_{\mathrm{CO} 2}=10^{-3.5} \mathrm{~atm}, 22.5^{\circ} \mathrm{C}$. Straight line: sorption isotherm; Dashed line: desorption isotherm. 
Table IV.3 Data of Freundlich sorption/desorption isotherms. Initial $[\mathrm{U}(\mathrm{VI})]$ ranged from $1.0 \times 10^{-7}$ to $2.0 \times 10^{-5} \mathrm{~mol} / \mathrm{L}$. Solution was saturated with calcite at $\mathrm{P}_{\mathrm{CO} 2}=10^{-3.5} \mathrm{~atm}$. Solid $/ \mathrm{solution}$ ratio $=$ $100 \mathrm{~g} / \mathrm{L}, \mathrm{I}=0.02 \mathrm{M}\left(\mathrm{NaNO}_{3}\right), \mathrm{T}=22.5^{\circ} \mathrm{C}$.

\begin{tabular}{|l|l|c|c|}
\hline & $\mathbf{p H}$ & \multicolumn{2}{|c|}{ Freundlich Model: S = $\mathbf{K}_{\mathbf{f}} \mathbf{C}^{\mathbf{n}}$} \\
\cline { 3 - 4 } & $\mathrm{K}_{\mathrm{f}}(\mu \mathrm{mol} / \mathrm{kg}) /(\mu \mathrm{mol} / \mathrm{L})^{\mathrm{n}}$ & $\mathbf{n}$ \\
\hline $\begin{array}{l}\text { original HSC, sorption } \\
\text { (Fig.IV.6) }\end{array}$ & $8.0 \pm 0.1$ & 34 & 0.75 \\
\hline $\begin{array}{l}\text { HSC silt/clay, sorption } \\
\text { (Figure IV.7) }\end{array}$ & $8.0 \pm 0.1$ & 33 & 0.77 \\
\hline $\begin{array}{l}\text { HSC silt/clay, desorption } \\
\text { (Figure IV.7) }\end{array}$ & $8.0 \pm 0.1$ & 48 & 0.80 \\
\hline
\end{tabular}

\subsection{Sequential Extraction}

Table IV.4 showed the removal efficiency of sorbed U(VI) from batch samples by the sequential extraction method. For the samples with initial concentration $\geq 5 \times 10^{-7} \mathrm{M}$ in sorption phase, the U(VI) extracted was almost $100 \%$ of the sorbed amount, with $\leq 5 \%$ error. For samples with lower initial concentrations in the sorption phase, however, more $\mathrm{U}(\mathrm{VI})$ than sorbed was extracted. It is noteworthy that the excess U(VI) extracted for $1 \times 10^{-7} \mathrm{M}$ and $2.5 \times 10^{-7} \mathrm{M}$ samples were $22.1 \mathrm{ng} / \mathrm{g}$ and $49.0 \mathrm{ng} / \mathrm{g}$ respectively, both greater than the background labile U(VI) at pH 8.0 (19.48ng/g, see Table IV.2). This indicates that some non-labile background U(VI) was released from the solid phase when the solids were being extracted. Such releasing process might involve the dissolution of $\mathrm{U}(\mathrm{VI})$ minerals.

In general, the results are very satisfactory and suggest that the sequential extraction method can be applied to the diffusion cell experiments. When U(VI) content in the solid phase is low, the extracted U(VI) may contain an excess fraction that is actually of the non-labile form. If the sorbed U(VI) (excluding the background) is greater than $150 \mathrm{ng} / \mathrm{g}$, this fraction should be less than $20 \%$ of the total sorbed U(VI).

Table IV.4. Removal efficiency of sorbed $\mathrm{U}(\mathrm{VI})$ by the sequential extraction procedure. Triplicate sample used for each initial $\mathrm{U}(\mathrm{VI})$ concentration.

\begin{tabular}{|c|c|c|c|}
\hline $\begin{array}{l}\text { Initial U } \\
\text { conc. }\end{array}$ & $\begin{array}{l}\text { Total } U(\mathrm{VI}) \text { sorbed } \\
\text { from solution }(\mathrm{ng} / \mathrm{g})\end{array}$ & $\begin{array}{c}\text { Total extracted } \mathrm{U}(\mathrm{VI}) \\
(\mathrm{ng} / \mathrm{g})\end{array}$ & $\begin{array}{l}\text { \% remv'd of the } \\
\text { sorbed U(VI) }\end{array}$ \\
\hline$-1 \times 10^{-7} M$ & $144.44 \pm 1.39$ & $176.37 \pm 2.03$ & $122.10 \pm 1.41$ \\
\hline$-2.5 \times 10^{-7} M$ & $329.28 \pm 2.71$ & $378.26 \pm 3.80$ & $114.87 \pm 1.15$ \\
\hline$-5 \times 10^{-7} M$ & $677.35 \pm 20.88$ & $689.69 \pm 21.25$ & $101.82 \pm 3.14$ \\
\hline$-1 \times 10^{-6} \mathrm{M}$ & $1331.61 \pm 22.95$ & $1277.48 \pm 22.98$ & $95.93 \pm 1.73$ \\
\hline$-2.5 \times 10^{-6} \mathrm{M}$ & $2620.98 \pm 17.74$ & $2604.22 \pm 17.87$ & $99.36 \pm 0.68$ \\
\hline$-5 \times 10^{-6} M$ & $4868.53 \pm 203.23$ & $4951.07 \pm 203.24$ & $101.70 \pm 4.17$ \\
\hline$-1 \times 10^{-5} \mathrm{M}$ & $9158.54 \pm 260.83$ & $9106.54 \pm 260.85$ & $99.43 \pm 2.85$ \\
\hline$-2.5 \times 10^{-5} \mathrm{M}$ & $18968.86 \pm 1005.70$ & $18984.22 \pm 1005.71$ & $100.08 \pm 5.30$ \\
\hline
\end{tabular}




\subsection{Diffusion Cell Experiments and Preliminary Modeling Results}

\section{Cell SC I}

Experimental data for diffusion cell SCI at the end of the diffusion phase are plotted in Figure IV.7. Figure IV.7(a) shows the data of sorbed phase U(VI) content, S, which was the total labile U(VI) in the solid phase obtained by the sequential extraction procedures. S was composed by two parts: the newly sorbed U(VI) from the pore water, and the background labile U(VI). This amount of background labile U(VI) was estimated to be $20.53 \mathrm{ng} / \mathrm{g}$, as given in the $6^{\text {th }}$ column of Table IV.2. Therefore, in each slice, the newly sorbed U(VI) content was calculated as the total extracted U(VI) minus the background labile U(VI).

U(VI) porewater concentration data, C, are plotted in Figure IV.7(b), along with a calculated porewater $\mathrm{U}(\mathrm{VI})$ concentration, $\mathrm{C}_{\mathrm{eq}}$, which is the expected concentration that would have been at equilibrium with $\mathrm{S}$. The relationship between $\mathrm{S}$ and $\mathrm{C}_{\text {eq }}$ was governed by the batch sorption isotherm at $\mathrm{pH} 8.0( \pm 0.1)$ : $\mathrm{S}=32.7417 \mathrm{C}_{\mathrm{eq}}{ }^{0.7710}$. As shown by the figure, for each slice, $\mathrm{C}$ and $\mathrm{C}_{\mathrm{eq}}$ values were generally in very good agreement except for the two slices at the right and left ends of the cell. These two slices showed much higher $\mathrm{S}$ values than expected. Because these two slices were in direct contact with the U(VI) stock solution in the reservoir tank, it is possible that some small volume of stock U(VI) solution was inadvertently included with these two slices when they were extruded from the column and cut off from the cell, thus resulting in a higher amount of total U(VI) and a higher estimation of S. Overall, the experimental data showed very good consistency with the local equilibrium assumption, as the measured total labile U(VI) concentrations in the solid phase were almost all at equilibrium with the measured porewater U(VI) concentrations on the basis of the batch isotherm. These results supported the local equilibrium assumption of Hypothesis II.

The results also suggest good consistency of sorption between the batch and column systems and imply that the extraction methods for both solid phase and porewater $\mathrm{U}(\mathrm{VI})$ are effective and reliable. Modeling results of U(VI) transport based on LEA using the batch isotherm are plotted in Figures IV.7(a) and (b). $\mathrm{D}_{\mathrm{e}, \mathrm{U}(\mathrm{VI})}$ was estimated by fitting the diffusion model to both $\mathrm{C}$ and $\mathrm{C}_{\mathrm{eq}}$, under the assumption that data of $\mathrm{C}_{\mathrm{eq}}$ were equally valid as those of $\mathrm{C}$ - i.e., assuming that the LEA model and S-value measurements were both valid. The overall fit is quite good, as based on a "best estimate" value of $\mathrm{D}_{\mathrm{e}, \mathrm{U}(\mathrm{VI})}=1.99 \times 10^{-6} \mathrm{~cm}^{2} / \mathrm{s}$. If the tortuosity factor of SCII $\left(\tau_{\mathrm{f}}=2.88\right.$; details of SCII $\tau_{\mathrm{f}}$ estimation are given in HSC-2 results.) was adopted for SCI, and assuming the constrictivity to be $1.0, \mathrm{D}_{0, \mathrm{U}(\mathrm{VI})}$ was estimated to be $5.73 \times 10^{-6} \mathrm{~cm}^{2} / \mathrm{s}$ for SCI.

Therefore, Hypothesis (4) given in "Project Objectives and Hypotheses", claiming that $\mathrm{U}(\mathrm{VI})$ diffusive transport could be fully interpreted by interparticle diffusion of $U(V I)$ in aqueous with equilibrium sorption to the sediment solid phase was supported by these results. 


\section{Cell SC II}

Experimental data and modeling results for diffusion cell SC II are shown in Figure IV.8 (a) and (b). Modeling of retarded U(VI) diffusive transport was performed assuming local equilibrium governed by the independently measured batch isotherm for HSC silt/clay at $\mathrm{pH} 8.0( \pm 0.1)$ (See Table IV.2). The modeling was conducted by solving Equation IV.3 numerically by using finite difference method (centered in space and forward in time). Modeling of HTO was conducted assuming no sorption to the solid phase. An optimal estimate of $\mathrm{D}_{\mathrm{e}, \mathrm{HTO}}=7.76 \times 10^{-6} \mathrm{~cm}^{2} / \mathrm{s}$ was found based on the principle of achieving the least sum of squares of the differences between model predictions and actual data (i.e. the least square method) for the HTO concentration in Figure IV.8 (a). With the known value of $\mathrm{D}_{0, \mathrm{HTO}}\left(2.236 \times 10^{-5} \mathrm{~cm}^{2} / \mathrm{s}\right)($ Mills, 1899$)$ and assuming constrictivity for HTO of 1.0, a tortuosity factor of $\tau_{\mathrm{f}}=2.88$ was obtained. (Refer to Equation IV.2). By modeling of the time-variant U(VI) concentration data in Figure IV.8(a), $\mathrm{D}_{\mathrm{e}, \mathrm{U}(\mathrm{VI})}$ was optimized to be $1.296 \times 10^{-6} \mathrm{~cm}^{2} / \mathrm{s}$ using the least square method. This estimate, when combined with the $\tau_{\mathrm{f}}$ value obtained from the HTO data, lead to an estimate to $\mathrm{D}_{0, \mathrm{U}(\mathrm{VI})} * \delta$ of $3.73 \times 10^{-6} \mathrm{~cm}^{2} / \mathrm{s}$, which was the product of molecular diffusion coefficient and constrictivity for $\mathrm{U}(\mathrm{VI})$. The $\mathrm{D}_{\mathrm{e}, \mathrm{U}(\mathrm{VI})}$ and $\mathrm{D}_{0, \mathrm{U}(\mathrm{VI})}$ values represented the diffusion coefficients of the overall U(VI) species, $>90 \%$ of which was $\mathrm{Ca}_{2} \mathrm{UO}_{2}\left(\mathrm{CO}_{3}\right)_{3}{ }^{0}$. (Refer to Figure 3.2). Since the HSC silt/clay material wasn't very compact in the diffusion cell, we assume the constrictivity for U(VI) species is 1.0. Therefore, we obtain $\mathrm{D}_{0, \mathrm{U}(\mathrm{VI})}$ to be $3.73 \times 10^{-6} \mathrm{~cm}^{2} / \mathrm{s}$. The $\mathrm{D}_{0}$ and De values for U(VI) obtained from this work and from literature are listed in Table IV.6. The $\mathrm{D}_{\mathrm{e}, \mathrm{U}(\mathrm{VI})}$ value estimated by SC II was smaller than that estimated by cell SC I. These $\mathrm{D}_{\mathrm{e}, \mathrm{U}(\mathrm{VI})}$ values, however, are still reasonably consistent, however, if we consider the fact that the tortuosity of the two cells may be somewhat different due to the variation in the packing of the solids. These $\mathrm{D}_{0}$ and $\mathrm{D}_{\mathrm{e}}$ values are comparable to literature values given in Table IV.6. 

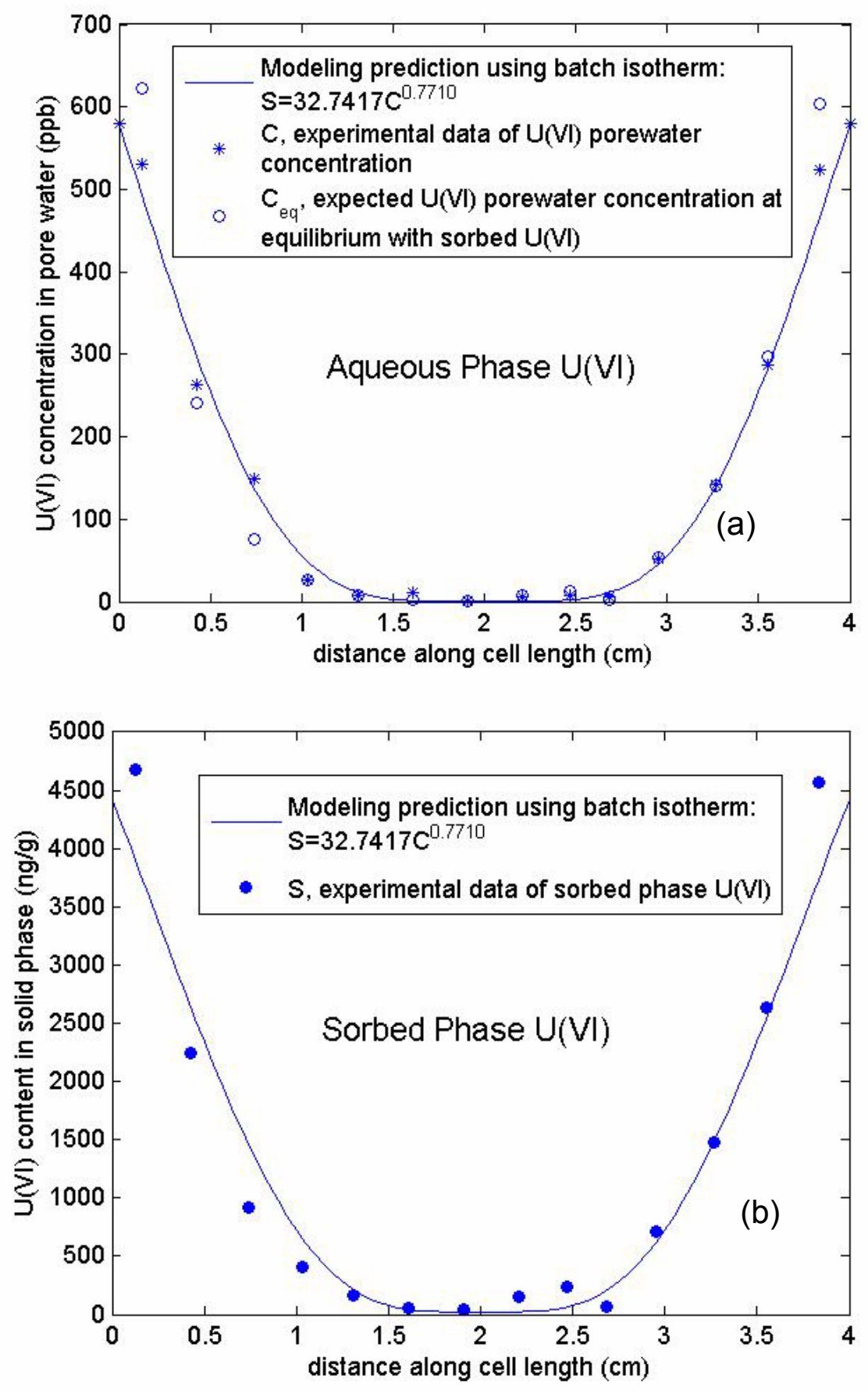

Figure IV.7. Results of the diffusion cell SC I. (a) Experimental data and modeling result of $\mathrm{U}(\mathrm{VI})$ content in the solid phase. Solid line: model prediction; solid circles: $\mathbf{S}$, measured $\mathrm{U}(\mathrm{VI})$ content in solid phase. (b) Experimental data and modeling results of $\mathrm{U}(\mathrm{VI})$ in the pore water. Solid line: model prediction; stars: $\mathbf{C}$, measured $\mathrm{U}(\mathrm{VI})$ porewater concentration; open circles: $\mathbf{C}_{\mathbf{e q}}$, expected $\mathrm{U}(\mathrm{VI})$ porewater concentration at equilibrium with $\mathrm{S}$. $\mathrm{U}(\mathrm{VI})$ sorptive diffusion transport model assumed local equilibrium using batch sorption isotherm: $S=32.7417 C^{0.7710} . C_{\text {eq }}$ was obtained as $C_{e q}=(S / 32.7417)^{(1 / 0.7710)}$. The effective diffusion coefficient, $D_{e, U(V)}$ was fitted to be $1.99 \times 10^{-6} \mathrm{~cm}^{2} / \mathrm{s}$ by fitting to both $\mathrm{C}$ and $\mathrm{C}_{\text {eq }}$. 
- HTO data in Source Chamber solution

- $\mathrm{U}(\mathrm{VI})$ data in Source Chamber solution
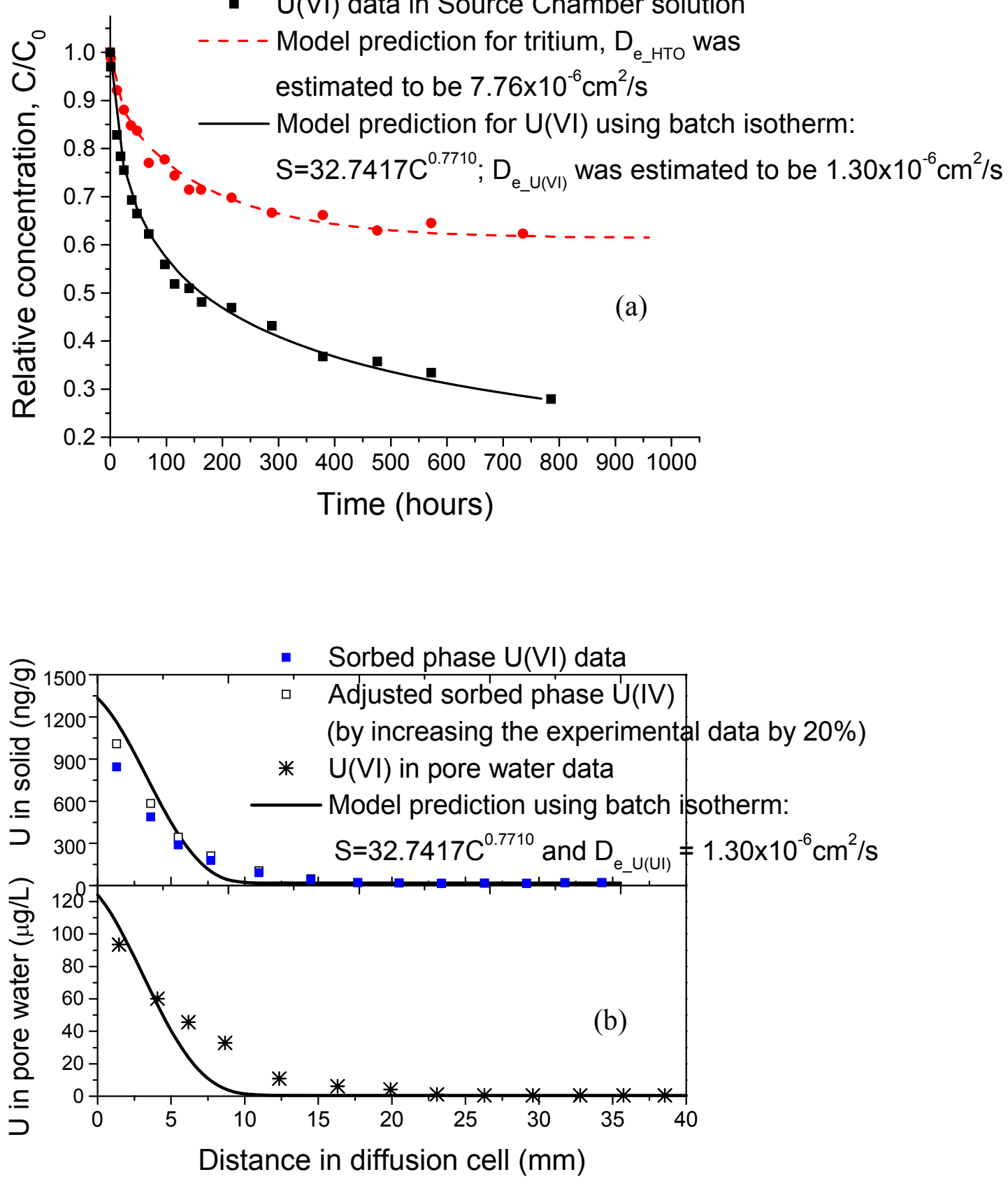

Figure IV.8. Results of the diffusion cell SC II. (a) Tritiated water (HTO) tracer and U(VI) concentrations in source solution chamber. Modeling of HTO diffusion yielded $\tau_{f}=2.88$ and $D_{e, H T O}$ $=7.76 \times 10^{-6} \mathrm{~cm}^{2} / \mathrm{s}$. U $(\mathrm{VI})$ sorptive diffusion transport model assumed local equilibrium using batch sorption isotherm: $S=32.7417 \mathrm{C}^{0.7710} \cdot \mathrm{D}_{\mathrm{e}, \mathrm{U}(\mathrm{VI})}=1.30 \times 10^{-6} \mathrm{~cm}^{2} / \mathrm{s}$ was estimated. (b) Experimental data and modeling results of $\mathrm{U}(\mathrm{VI})$ concentration profiles in the pore water and the solid phase. Mass balance calculation showed only $83.9 \%$ of solid phase $\mathrm{U}(\mathrm{VI})$ was extracted relative to the loss from solution. The adjusted solid phase $\mathrm{U}(\mathrm{VI})$ data were obtained by increasing the experimental solid phase $\mathrm{U}(\mathrm{VI})$ data by $20 \%$ to simulate the data when all sorbed $\mathrm{U}(\mathrm{VI})$ was extracted. $D_{e, U(V I)}$ value estimated from (a) was used in the modeling of $U(V I)$ profiles. 
Figure IV.8(b) shows U(VI) concentration data for both the pore water and the solid phase. As with cell SC I, the solid phase U(VI) data represent the total labile U(VI). The modeling prediction was made by using the $\mathrm{D}_{\mathrm{e}, \mathrm{U}(\mathrm{VI})}$ value estimated from the data in Figure IV.8(a) and assuming local equilibrium. Experimental results in pore water were reliable; however, a mass balance calculation relative to the estimated total mass loss from solution suggests that only $83.9 \%$ of the newly sorbed U(VI) was extracted from the solid phase. This insufficient extraction could be the result of insufficient time for extraction (6 days for each of the four steps). By contrast, the solids in the other cell (SC I) were extracted for 2-4 weeks during each of the four extraction steps.

In an attempt to account for the missing mass, the solid phase U(VI) data (solid squares in Figure IV.8(b)) were raised by $20 \%$. These adjusted results are shown as open squares in Figure IV.8(b), and all results (experimental, adjusted experimental, and model data) are as listed in Table IV.5. It can be seen from this table that even after the extracted mass was adjusted, U(VI) in the solid phase was still not sufficiently high to meet expected values as calculated on the basis of the LEA. In addition to this, modeling results using the LEA and the estimated $\mathrm{D}_{\mathrm{e}, \mathrm{U}(\mathrm{VI})}$ showed that $\mathrm{U}(\mathrm{VI})$ transported further into the cell than predicted by the model. Such faster transport could be caused by nonequilibrium of sorption - i.e., that U(VI) was not as strongly retarded in the diffusion cell as it was in the batch system. Thus, and in contrast to the results of cell SC I, the LEA proposed in "Project Objectives and Hypotheses" might not be true for cell SC II.

The cause of non-equilibrium sorption in cell SC II has yet to be explored. The overall porewater U(VI) concentration in SC I was much higher than that in SC II. We hypothesize that some kinetic processes may become more rate-controlling at lower U(VI) concentration, causing non-equilibrium in SC II only. For example, the apparent intra-particle diffusivity is expected to be less at low concentration due to the fact that U(VI) sorption is stronger at these concentrations owing to the nonlinearity of the isotherm, as evident from Figure IV.6. (In other words, if we represent retardation by $\mathrm{dS} / \mathrm{dC}$, where $\mathrm{S}$ and $\mathrm{C}$ are $\mathrm{U}(\mathrm{VI})$ concentrations in the solid phase and aqueous phase respectively, then higher values of $\mathrm{dS} / \mathrm{dC}$ will be experienced at low $\mathrm{C}$.)

The above hypothesis can also be explained in terms of a characteristic time $t_{D}$ for intraparticle diffusion. Such a characteristic time represents an order-of-magnitude estimate of the time required for diffusion to occur over a specific length, which in this case is the approximate radius of the grain, $a . t_{D}$ can be defined as:

$$
t_{D}=\frac{a^{2}}{D_{a}}
$$

$D_{a}$ is defined as the apparent diffusion coefficient, we have the following expression for $D_{a}$, where $R$ is called the retardation factor:

$$
D_{a}=\frac{D_{e}}{\left(1+\frac{(1-\varepsilon)}{\varepsilon} \rho_{s} d S / d C\right)}=\frac{D_{e}}{R}
$$

Note that smaller characteristic transport times are obtained for larger $D_{a}$ and smaller $a$ values. Therefore, at lower U(VI) concentrations (in SC II), $D_{a}$ will be smaller and $t_{D}$ 
larger, reflecting the slowed transport and long equilibration times that is associated with strong sorption. Under such conditions, the LEA is more likely to be invalid.

It is noteworthy, however, that the relative rates of inter- and intra-particle transport are both affected by increases or decreases in sorption. Thus, effects on transport are not quite so straight-forward to predict. Moreover, U(VI) sorption and desorption processes in the Hanford sediments can be much more complicated owing to the heterogeneity of sorption and diffusion processes and because of the possibility of chemical rate controls. Further work is needed to include an intra-particle diffusion model or an empirical kinetic model in the U(VI) transport model and to thus provide a more thorough test of our hypothesis that these kinetics are controlled by intra-particle diffusion. More diffusion cell experiments with varied chemical conditions, such as initial U(VI) concentration, ionic strength, etc. could provide more thorough evaluation of these hypotheses, while also perhaps allowing better estimates of relative $D_{e}$ values.

The different observations of SCI and SCII show the value of using two alternative cell designs and concentrations. In addition to allowing an independent measure of the tortuosity factor for HTO diffusion, the SCII cell provided three sets of $\mathrm{U}(\mathrm{VI})$ data, thus giving more information and providing multiple model fitting options. Since this cell system is closed, mass balance calculations can be applied to test the extraction efficiency. In addition, by using various U(VI) concentrations, kinetic effects on U(VI) diffusion under various U(VI) concentrations can be studied.

Table IV.5 U(VI) concentration data in diffusion cell SCII. Adjusted solid phase $\mathrm{U}(\mathrm{VI})$ concentrations were obtained by raising the measured data by $20 \%$. Solid phase $U(\mathrm{VI})$ based on LEA was calculated from pore water $\mathrm{U}(\mathrm{VI})$ concentration using batch sorption isotherm: $\mathrm{S}=$ $32.7417 \mathrm{C}^{0.7710}, \mathrm{C}$-pore water $\mathrm{U}(\mathrm{VI})$, S-solid phase $\mathrm{U}(\mathrm{VI})$.

\begin{tabular}{|c|c|c|c|c|c|}
\hline $\begin{array}{c}\text { SC II } \\
\text { Slice number }\end{array}$ & $\begin{array}{l}\text { Distance } \\
\text { (cm) }\end{array}$ & $\begin{array}{c}\text { Pore water } \mathrm{U}(\mathrm{VI}) \\
\text { concentration }(\mathrm{ppb}) \\
\left(^{*} \text { in Figure IV.8(b)) }\right.\end{array}$ & $\begin{array}{l}\text { Measured solid phase } \\
\text { labile U(VI) (ng/g) } \\
\text { (घ in Figure IV.8(b)) }\end{array}$ & $\begin{array}{c}\text { Adjusted solid phase } \\
\text { labile U(VI) (ng/g) } \\
\text { ( } \square \text { in Figure IV.8(b)) }\end{array}$ & $\begin{array}{c}\text { Solid phase labile } \\
\text { U(VI) } \\
\text { by LEA (ng/g) }\end{array}$ \\
\hline 1 & 1.46 & 93.5 & 845.00 & 1010.12 & 1083.3 \\
\hline 2 & 4.08 & 60.1 & 490.88 & 585.17 & 770.7 \\
\hline 3 & 6.18 & 45.6 & 290.84 & 345.13 & 622.9 \\
\hline 4 & 8.61 & 32.9 & 180.54 & 212.77 & 484.1 \\
\hline 5 & 12.19 & 10.8 & 92.52 & 107.15 & 205.4 \\
\hline 6 & 16.06 & 6.1 & 44.12 & 49.07 & 132.1 \\
\hline 7 & 19.56 & 4.1 & 22.26 & 22.83 & 97.8 \\
\hline 8 & 22.61 & 1.1 & 19.36 & 19.36 & 34.7 \\
\hline 9 & 25.74 & 0.5 & 17.22 & 16.78 & 19.4 \\
\hline 10 & 28.93 & 0.5 & 18.80 & 18.68 & 19.4 \\
\hline 11 & 32.04 & 0.5 & 16.76 & 16.24 & 19.4 \\
\hline 12 & 34.89 & 0.5 & 21.74 & 22.21 & 19.4 \\
\hline 13 & 37.61 & 0.5 & 22.48 & 23.10 & 19.4 \\
\hline
\end{tabular}




\section{Conclusions}

In this work, two types of diffusion cells with the HSC silt/clay material were constructed and then operated under strictly controlled chemical conditions. The purpose was to obtain the effective diffusion coefficient of U(VI) and test the hypothesis that $\mathrm{U}(\mathrm{VI})$ diffusion in the silt/clay porous medium was controlled by inter-particle diffusion at local equilibrium with respect to sorption. Independent batch sorption/desorption experiments were conducted to obtain sorption/desorption isotherms and kinetic information. Special methods concerning the saturation and equilibration of the solid material, the extraction of the solid phase U(VI), and the measurement of tortuosity factor of the porous solid medium were developed.

Results showed that both diffusion cell designs were effective for studying and modeling U(VI) retarded diffusion. Although Type I diffusion cell results could be successfully modeled using the local equilibrium assumption (LEA), results of the Type II diffusion cell showed features of non-equilibrium sorption and faster migration (i.e. less retardation). We attribute these observations to the lower aqueous U(VI) concentrations in the SCII experiments, which presume to have caused local nonequilibrium due to slow intraparticle diffusion. Thus, the use of both cell designs proved to be a valuable approach for a thorough investigation of diffusion. Overall, the extraction methods and cell designs demonstrated here are useful additions to the body of experimental techniques that are available for use in studying actinide and heavy metal diffusion in porous media. Further work is needed to develop a model that incorporates both inter- and intra-particle diffusion and to better understand the impact of intra-particle diffusion on $\mathrm{U}(\mathrm{VI})$ retarded diffusive transport. 
Table IV.6 Summary of diffusion coefficients of uranyl species.

\begin{tabular}{|c|c|c|c|c|c|}
\hline species & condition & method & $D_{0}\left(\mathrm{~cm}^{2} / \mathrm{s}\right)$ & $D_{e}\left(\mathrm{~cm}^{2} / \mathrm{s}\right)$ & source \\
\hline $\begin{array}{l}\text { Uranyl (hydroxyl) carbonates } \\
\left(>90 \% \text { is } \mathrm{Ca}_{2} \mathrm{UO}_{2}\left(\mathrm{CO}_{3}\right)_{3}{ }^{0}\right)\end{array}$ & $\begin{array}{l}\mathrm{pH} 8.0( \pm 0.1), 22.5^{\circ} \mathrm{C}, \\
\text { in HSC silt/clay }\end{array}$ & $\begin{array}{l}\text { Type I diffusion cell } \\
\text { experiment }\end{array}$ & $5.73 \times 10^{-6}$ & $1.99 \times 10^{-6}$ & SC I of this work \\
\hline $\begin{array}{l}\text { Uranyl (hydroxyl) carbonates } \\
\left(>90 \% \text { is } \mathrm{Ca}_{2} \mathrm{UO}_{2}\left(\mathrm{CO}_{3}\right)_{3}{ }^{0}\right)\end{array}$ & $\begin{array}{l}\mathrm{pH} 8.0( \pm 0.1), 22.5^{\circ} \mathrm{C} \\
\text { in HSC silt/clay }\end{array}$ & $\begin{array}{l}\text { Type II diffusion cell } \\
\text { experiment }\end{array}$ & $3.74 \times 10^{-6}$ & $1.30 \times 10^{-6}$ & SC II of this work \\
\hline $\mathrm{UO}_{2}^{2+}$ & $21^{\circ} \mathrm{C}, \mathrm{pH}<5$, dilution solutions & theoretical prediction & $6.1 \times 10^{-6}$ & -- & Tokunaga, et al., (2004) \\
\hline uranyl (hydroxyl) carbonates & $21^{\circ} \mathrm{C}, \mathrm{pH}<5$, dilution solutions & theoretical prediction & $3.0( \pm 1.0) \times 10^{-6}$ & -- & Tokunaga, et al., (2004) \\
\hline $\mathrm{UO}_{2}^{2+}$ & $25^{\circ} \mathrm{C}$ & theoretical prediction & $6.8 \times 10^{-6}$ & -- & Millard and Hedges (1996) \\
\hline $\mathrm{UO}_{2}{ }^{2+}$ species & $\begin{array}{l}\text { in compact bentonite } \\
\mathrm{pH} \text { not given }\end{array}$ & diffusion cell experiment & -- & $\begin{array}{l}1.08 \times 10^{-9} \\
\text { to } 1.27 \times 10^{-7}\end{array}$ & Muurinen (1990) \\
\hline $\mathrm{UO}_{2}^{2+}$ & $\begin{array}{l}\text { in Inada granite rock matrix } \\
\mathrm{pH} 4.0,25( \pm 1)^{\circ} \mathrm{C}\end{array}$ & $\begin{array}{l}\text { experimental }\left(D_{e}\right) \\
\text { and theoretical }\left(D_{0}\right)\end{array}$ & $4.3( \pm 0.6) \times 10^{-6}$ & $5.14( \pm 2.3) \times 10^{-8}$ & Yamaguchi, et al., (1997) \\
\hline $\begin{array}{l}\text { uranyl (hydroxyl) } \\
\text { carbonates, mostly } \cup_{2}\left(\mathrm{CO}_{3}\right)_{3}{ }^{4-}\end{array}$ & $\begin{array}{l}\text { in Inada granite rock matrix*, } \\
\mathrm{pH} 9.2,25( \pm 1)^{\circ} \mathrm{C}\end{array}$ & diffusion cell experiment & 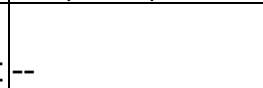 & $2.03( \pm 0.34) \times 10^{-7}$ & Yamaguchi, et al., (1997) \\
\hline $\begin{array}{l}\text { uranyl (hydroxyl) } \\
\text { carbonates,mostly } \cup_{2}\left(\mathrm{CO}_{3}\right)_{3}{ }^{4-}\end{array}$ & $\begin{array}{l}\text { in Inada granite rock matrix } \\
\mathrm{pH} 9.2,25( \pm 1)^{\circ} \mathrm{C}\end{array}$ & theoretical prediction & $7.2( \pm 0.5) \times 10^{-6}$ & -- & Yamaguchi, et al., (1998) \\
\hline
\end{tabular}

$*$ Note that the Inada granite rock is a low-porosity medium (porosity $\varepsilon=0.007$ ). 


\section{References}

Arai, Y., McBeath, M., Bargar, J.R., Joye, J. and Davis, J.A., 2006. Uranyl adsorption and surface speciation at the imogolite-water interface: Self-consistent spectroscopic and surface complexation models. Geochimica et Cosmochimica Acta, 70: 2492-2509.

Arnold, B.W., Kuzio, S.P. and Robinson, B.A., 2003. Radionuclide transport simulation and uncertainty analyses with the saturated-zone site-scale model at Yucca Mountain, Nevada. J. Cont. Hydrol., 63: 401-419.

Ball, W.P. and Roberts, P.V., 1991. Diffusive rate limitations in the sorption of organic chemicals. Organic Substances and Sediments in Water: Volume 2, Processes and Analytical. Lewis Publishers, Inc., Chelsea, MI.

Bargar, J.R., Reitmeyer, R. and Davis, J.A., 1999. Spectroscopic confirmation of uranium(VI) - carbonato adsorption complexes on hematitle. Environ. Sci. Technol., 33: 2481-2484.

Bargar, J.R., Reitmeyer, R., Lenhart, J.J. and Davis, J.A., 2000. Characterization of U(VI)-carbonato ternary complexes on hematite: EXAFS and electrophoretic mobility measurements. Geochimica et Cosmochimica Acta, 64: 2737-2749.

Barnett, M.O., Jardine, P.M. and Brooks, S.C., 2002. U(VI) adsorption to heterogeneous subsurface media: Application of a surface complexation model. Environ. Sci. Technol., 36: 937-942.

Bernhard, G., Geipel, G., Brendler, V. and Nitsche, H., 1996. Speciation of uranium in seepage waters of a mine tailing pile studied by time-resolved laser-induced fluorescence spectroscopy (TRLFS). Radiochim. Acta, 74: 87-91.

Bernhard, G. et al., 2001. Uranyl(VI) carbonate complex formation: Validation of the $\mathrm{Ca}_{2} \mathrm{UO}_{2}\left(\mathrm{CO}_{3}\right)_{3}(\mathrm{aq})$ species. Radiochim. Acta, 89: 511-518.

Bethke, C.M. and Brady, P.V., 2000. How the K-d approach undermines ground water cleanup. Ground Water, 38: 435-443.

Cheng, T., Barnett, M.O., Roden, E.E. and Zhuang, J., 2006. Effects of solid-solution ratio on uranium(VI) adsorption and its implications. Environ. Sci. Technol., 40: 3243-3247.

Chisholm-Brause, C.J., Berg, J.M., Marzner, R.A. and Morris, D.E., 2001. Uranium(VI) sorption complexes on montmorrillonite as a function of solution chemistry. J. Col. Interface Sci., 233: 38-49.

Crank, J., 1976. The Mathematics of Diffusion, 2nd Edition. Oxford Press.

Curtis, G.P., Davis, J.A. and Naftz, D.L., 2006. Simulation of reactive transport of uranium(VI) in groundwater with variable chemical conditions. Water Resources Research, 42: W04404.

Curtis, G.P., Fox, P., Kohler, M. and Davis, J.A., 2004. Comarison of in situ uranium $\mathrm{K}_{\mathrm{D}}$ values with a laboratory determined surface complexation model. App. Geochem., 19: 1643-1653.

Cussler, E.L., 1997. Diffusion Mass Transfer in Fluid Systems. Cambridge University Press, New York.

Davis, J.A. (Editor), 2001. Surface Complexation Modeling of Uranium(VI) Adsorption on Natural Mineral Assemblages, NUREG/CR - 6708. Office of Nuclear 
Regulatory Research, U.S. Nuclear Regulatory Commission, Washington, D.C., $214 \mathrm{pp}$.

Davis, J.A., Coston, J.A., Kent, D.B. and Fuller, C.C., 1998. Application of the surface complexation concept to complex minerals assemblages. Environ. Sci. Technol., 32: 2820-2828.

Davis, J.A., Meece, D.E., Kohler, M. and Curtis, G.P., 2004. Approaches to surface complexation modeling of uranium(VI) adsorption on aquifer sediments. Geochim. Cosmochim. Acta, 68: 3621-3641.

Davis, J.A., Payne, T.E. and Waite, T.D., 2002. Simulating the $\mathrm{pH}$ and $\mathrm{pCO}_{2}$ dependence of uranium(VI) adsorption by a weathered schist with surface complexation models. Geochemistry of Soil Radionuclides, SSSA Special Publication, 59: 6186.

Dong, W.M. et al., 2005. Influence of calcite and dissolved calcium on uranium(VI) sorption to a Hanford subsurface sediment. Environ. Sci. Technol., 39: 79497955.

Fox, P.M., Davis, J.A. and Zachara, J.M., 2006. The effect of calcium on aqueous uranium(VI) speciation and adsorption to ferrihydrite and quartz. Geochimica et Cosmochimica Acta, 70: 1379-1387.

Gamerdinger, A.P., Kaplan, D.I., Wellman, D.M. and Serne, R.J., 2001. Two-region flow and rate-limited sorption of uranium (VI) during transport in an unsaturated silt loam. Water Resour. Res, 37(12): 3147-3153.

Grathwohl, P., 1998. Diffusion in Natural Porous Media: Contaminant Transport, Sorption/Desorption and Dissolution Kinetics. Kluwer Academic Publishers.

Kaplan, D.I., Gervais, T.L. and Krupka, K.M., 1998. Utanium(VI) sorption to sendiments under high $\mathrm{pH}$ and ionic strength conditions. Radiochim. acta, 80: 201-211.

Kohler, M., Curtis, G.P., Kent, D.B. and Davis, J.A., 1996. Experimental investigation and modeling of uranium(VI) transport under variable chemical conditions. Environ. Sci. Technol., 32(12): 3539-3551.

Kohler, M., Curtis, G.P., Meece, D.E. and Davis, J.A., 2004. Methods for estimating adsorbed uranium(VI) and distribution coefficients of contaminated sediments. Environ. Sci. Technol., 38: 240-247.

Li, Y.H. and Gregory, S., 1974. Diffusion of ions in sea-water and in deep-sea sediments. Geochimica et Cosmochimica Acta, 38: 703-714.

Liu, C. et al., 2004. Dissolution of uranyl microprecipitates from subsurface sediments at Hanford Site, USA. Geochim. Cosmochim. Acta, 68: 4519-4537.

Liu, C.X., Zachara, J.M., Yantasee, W., Majors, P.D. and McKinley, J.P., In press. Microscopic reactive diffusion of Uranium in the contaminated sediments at Hanford, USA: characterization and modeling.

McKinley, J.P., Zachara, J.M., Smith, S.C. and Turner, G.D., 1995. The influence of uranyl hydrolysis and multiple site-binding reactions on adsorption of U(VI) to montmorillonite. Clays and Clay Minerals, 43: 586-598.

Mehra, O.P. and Jackson, M.L., 1960. Iron oxides removal from soils and clays by a dithionite-citrate system buffered with sodium bicarbonate, 7th Natl. Conf. Clays and Clay Minerals, pp. 317-327. 
Millard, A.R. and Hedges, R.E.M., 1996. A diffusion-adsorption model of uranium uptake by archaeological bone. Geochimica et Cosmochimica Acta, 60: 21392152.

Mills, R., 1899. Self-diffusion measurements in simple and complex liquids. Molecular Motions in Liquids. Springer.

Muurinen, A., 1990. Diffusion of uranium in compacted sodium bentonite. Eng. Geo., 28: 359-367.

Payne, T.E., Davis, J.A. and Waite, T.D., 1994. Uranium retention by weathered schists the role of iron minerals. Radiochim. Acta, 66/67: 297-303.

Payne, T.E., Lumpkin, G.R. and Waite, T.D., 1998. Uranium(VI) adsorption on model minerals: controlling factors and surface complexation modeling. In: E.A. Jenne (Editor), Adsorption of Metals by Geomedia: Variables, Mechanisms and Model Applications. Academic Press, San Diego, CA, pp. 75-97.

Payne, T.E. and Waite, T.D., 1991. Surface complexation modeling of uranium sorption data obtained by isotope exchange techniques. Radiochimica Acta, 52: 487-493.

Qafoku, N.P. et al., 2005. Kinetic desorption and sorption of U(VI) during reactive transport in a contaminated Hanford sediment. Environ. Sci. Technol., 39: 31573165.

Reeder, R. et al., 2001. Coprecipitation of uranium(VI) with calcite: XAFS, micro-XAS, and luminescence characterization. Geochimca et Cosmochimca Acta, 65(20): 3491-3503.

Reeder, R.J., Nugent, M., Lamble, G.M., Tait, C.D. and Morris, D.E., 2000. Uranyl incorporation into calcite and aragonite: XAFS and luminescence studies. Environmental Science \& Technology, 34(4): 638-644.

Riley, R.G., Zachara, J.M. and Wobber, F.J., 1992. Chemical contaminant mixtures for subsurface science research on DOE lands and selection of contaminants. U.S. Department of Energy.

Ross, G.J. and Wang, C., 1993. Chap.25 Extractable Al, Fe, Mn, and Si. In: M.R. Carter (Editor), Soil Sampling and Methods of Analysis. Can. Soc. Soil Sci., pp. 239246.

Serne, R. et al., 2002. Characterization of vadose zone sediment: uncontaminated RCRA borehole core samples and composite samples. PNNL-13757-1, Pacific Northwest National Laboratory, Richland, WA.

Tokunaga, T.K. et al., 2005. Uranium reduction in sediments under diffusion-limited transport of organic carbon. Environ. Sci. Technol., 39: 7077-7083.

Tokunaga, T.K., Wang, J.M., Pena, J., Sutton, S.R. and MNewville, M., 2004. Hexavalent uranium diffusion into soils from concentrated acidic and alkaline solutions. Environ. Sci. Technol., 38: 3056-3062.

Turner, G.D., Zachara, J.M., McKinley, J.P. and Smith, S.C., 1996. Surface-charge properties and $\mathrm{UO}_{2}{ }^{2+}$ adsorption of a subsurface smectite. Geochim. Cosmochim. Acta, 60(18): 3399-3414.

Yamaguchi, T. and Nakayama, S., 1998. Diffusivity of U, Pu and Am carbonate complexes in a granite from Inada, Ibaraki, Japan studied by through diffusion. J. Cont. Hydrol., 35: 55-65. 
Yamaguchi, T., Sakamoto, Y., Nakayama, S. and Vandergraaf, T.T., 1997. Effective diffusivity of the uranyl ion in a granite from Inada, Ibaraki, Japan. J. Cont. Hydrol., 26: 109-117.

Zachara, J.M., Cowan, C.E. and Resch, C.T., 1991. Sorption of divalent metals on calcite. Geochim. Cosmochim. Acta, 55: 1549-1562.

Zachara, J.M. et al., 2002. Sorption of $\mathrm{Cs}^{+}$to micaceous subsurface sediments from the Hanford site, USA. Geochim. Cosmochim. Acta, 66: 193-211.

Zheng, Z., Tokunaga, T.K. and Wan, J., 2003. Influence of calcium carbonate on U(VI) sorption to soils. Environ. Sci. \& Technol., 37: 5603-5608. 
Appendix I

\section{Appendix I}

\section{Contents of Appendix I:}

- Influence of Calcite and Dissolved Calcium on U(VI) Sorption to a Hanford Subsurface Sediment (paper published in Environmental Science \& Technology, 39: 7949-7955 )

- Supporting Information for "Influence of Calcite and Dissolved Calcium on U(VI) Sorption to a Hanford Subsurface Sediment” 


\title{
Influence of Calcite and Dissolved Calcium on U(VI) Sorption to a Hanford Subsurface Sediment
}

\author{
Wenming Dong ${ }^{1,3}$, William P. Ball ${ }^{1 *}$, Chongxuan Liu ${ }^{2}$, \\ Zheming Wang ${ }^{2}$, Alan T. Stone ${ }^{1}$, Jing Bai ${ }^{1}$, and John M. Zachara ${ }^{2}$ \\ ${ }^{1}$ Department of Geography and Environmental Engineering, Johns Hopkins \\ University, 313 Ames Hall, 3400 North Charles Street, Baltimore, MD 21218 \\ ${ }^{2}$ Pacific Northwest National Laboratory, Environmental Dynamics and \\ Simulations, Richland, WA 99352 \\ 3 Currently with Environmental Sciences Division, Oak Ridge National \\ Laboratory, Oak Ridge, TN 37831-6038 \\ * Corresponding Author: Tel: (410) 516-5434; e-mail: bball@jhu.edu
}

submitted to Environmental Science and Technology

(August 2005) 


\begin{abstract}
The influence of calcite and dissolved calcium on U(VI) adsorption was investigated using a calcite-containing sandy silt/clay sediment from the U.S. Department of Energy (DOE) Hanford site. U(VI) adsorption to sediment, treated sediment, and sediment size fractions was studied in solutions that both had and had not been preequilibrated with calcite, at initial $[\mathrm{U}(\mathrm{VI})]=10^{-7}-10^{-5} \mathrm{~mol} / \mathrm{L}$, and final $\mathrm{pH}=6.0-10.0$. Kinetic and reversibility studies ( $\mathrm{pH} 8.4$ ) showed rapid sorption (30 minutes), with reasonable reversibility in the 3-day reaction time. Sorption from solutions equilibrated with calcite showed maximum $\mathrm{U}(\mathrm{VI})$ adsorption at $\mathrm{pH} 8.4 \pm 0.1$. In contrast, calcium-free systems showed greatest adsorption at $\mathrm{pH}$ 6.0-7.2. At $\mathrm{pH}>8.4, \mathrm{U}(\mathrm{VI})$ adsorption was identical from calcium-free and calcium-containing solutions. For calcite pre-saturated systems, both speciation calculations and laser-induced fluorescence spectroscopic (LIFS) analyses indicated that aqueous U(VI) was increasingly dominated by $\mathrm{Ca}_{2} \mathrm{UO}_{2}\left(\mathrm{CO}_{3}\right)_{3}{ }^{0}(\mathrm{aq})$ at $\mathrm{pH}<8.4$ and that formation of $\mathrm{Ca}_{2} \mathrm{UO}_{2}\left(\mathrm{CO}_{3}\right)_{3}{ }^{0}(\mathrm{aq})$ is what suppresses $\mathrm{U}(\mathrm{VI})$ adsorption. Above $\mathrm{pH} 8.4$, aqueous $\mathrm{U}(\mathrm{VI})$ speciation was dominated by $\mathrm{UO}_{2}\left(\mathrm{CO}_{3}\right)_{3}{ }^{4-}$ in all solutions. Finally, results also showed that U(VI) adsorption was additive in regard to size fraction, but not in regard to mineral mass: carbonate minerals may have blocked U(VI) access to surfaces of higher sorption affinity.
\end{abstract}




\section{Introduction}

Uranium (VI) is a common contaminant at sites of nuclear materials processing and U mining (1,2). At the U.S. Department of Energy (DOE) Hanford site, groundwater containing U(VI) has high probability of discharging to the nearby Columbia river (3). For this and other sites, an important aspect of both risk assessment and the evaluation of remediation alternatives is to project the rate of $U(V I)$ migration in subsurface environments. In-ground mobility of uranium(VI) is typically controlled by sorption and desorption processes which are in turn influenced by U(VI) speciation and sorbent properties.

U(VI) species can adsorb to phyllosilicates both by ion exchange to fixed charge sites $(4,5)$ and by surface complexation with amphoteric hydroxyl edge sites (4-6). Surface complexation of U(VI) has been well studied with hematite (7), goethite (8), ferrihydrite $(9,10)$, quartz (11), clinoptilite (12), and gibbsite (9). Although ion exchange and surface complexation models have been developed for describing U(VI) adsorption to various minerals, such models are difficult to apply to natural sediments in a predictive sense, owing to difficulty in characterizing the quantity of available sites, especially for natural materials where some mineral phases occlude access to others.

Calcite is a known sorbent for various divalent cations including $\mathrm{Mn}^{2+}, \mathrm{Fe}^{2+}, \mathrm{Cd}^{2+}$, $\mathrm{Co}^{2+}, \mathrm{Zn}^{2+}, \mathrm{Ca}^{2+}, \mathrm{Sr}^{2+}, \mathrm{Ba}^{2+}$ (13-15), and U(VI) (16). Calcite is a minor mineralogical component in many sediments and typically exists as a form of cement or coating material that can aggregate other minerals and/or cover their surfaces $(17,18)$. At the Hanford site, calcite is a common mineral component, with which porewater is often at equilibrium (19). Calcite can affect U(VI) adsorption to mineral assemblages through its direct role as an adsorbent but may also block sorbate access to other solids. Additionally, dissolved $\mathrm{Ca}^{2+}$ and carbonate from calcite can complex with U(VI) to form $\mathrm{Ca}_{2} \mathrm{UO}_{2}\left(\mathrm{CO}_{3}\right)_{3}{ }^{0}{ }_{\text {(aq) }}$ and $\mathrm{UO}_{2}\left(\mathrm{CO}_{3}\right)_{3}{ }^{4-}$ species at circumneutral to alkaline $\mathrm{pH}$ conditions $(20,21)$. In fact, $\mathrm{Ca}_{2} \mathrm{UO}_{2}\left(\mathrm{CO}_{3}\right)_{3}{ }^{0}$ (aq) has been found to be a major aqueous U(VI) species in the vadose porewater at the Hanford site $(19,22)$. A recent study (23) showed that the presence of calcium carbonate in soils can suppress $\mathrm{U}(\mathrm{VI})$ sorption in the $\mathrm{pH}$ range of about $6-9$, and that calcite can be a source of dissolved calcium for formation of the neutral U(VI) complex $\left(\mathrm{Ca}_{2} \mathrm{UO}_{2}\left(\mathrm{CO}_{3}\right)_{3}{ }^{0}(\mathrm{aq})\right.$ (23).

In this study, we investigated the influence of calcite $\left(\mathrm{CaCO}_{3(\mathrm{~S})}\right)$ and aqueous calcium on U(VI) adsorption with a calcite-containing sediment from the U.S. DOE Hanford site. U(VI) adsorption was studied onto collected Hanford sediment, its size fractions, and both untreated (carbonate-containing) and treated (carbonate-free) samples of the silt/clay fraction. These studies were conducted at circumneutral $\mathrm{pH}$ to alkaline/calcareous conditions that are representative of the Hanford groundwater system. The aqueous U(VI) speciation was monitored using laser-induced fluorescence spectroscopy (LIFS) and also calculated using equilibrium speciation models. The results were also used to test whether U(VI) adsorption to the whole sediment material could be conceived as an additive process in terms of either size fractions or mineral components.

\section{Materials and Experimental Procedures}

Materials. The sediment used in this study was a composite of sand- and silt-sized aggregates of finer grained materials that were collected from a background borehole 
(RCRA borehole \# 299-W22-48, 24) beneath the U.S. DOE Hanford site at selected depth intervals between 42 and 44 meters below ground surface. Nearby U(VI) plumes exist in these same sediment types. The $\mathrm{pH}$ in porewater and groundwater at the Hanford site is variable, mostly ranging from 6.5 to 10 depending on specific locations (24). Sediment in the zone of sampling was largely dominated by quartz ( $45 \%$ to $95 \%)$, plagioclase feldspar ( $\sim 10 \%$ to $20 \%)$, and alkali feldspar ( $20 \%$ to $40 \%)$ (24). Specific XRD analysis of the HSC sample (unpublished data, PNL, 2004) revealed that major mineral components of the composite are: quartz $\left(\mathrm{SiO}_{2}\right)$, albite $\left(\mathrm{NaAlSi}_{3} \mathrm{O}_{8}\right)$, clinochlore $\left[(\mathrm{Mg}, \mathrm{Fe})_{6}(\mathrm{Si}, \mathrm{Al})_{4} \mathrm{O}_{10}(\mathrm{OH})_{8}\right]$, potassicpargasite $\left[\mathrm{KCa}_{2}\left(\mathrm{Mg}_{3} \mathrm{FeAl}\right)\left(\mathrm{Si}_{6} \mathrm{Al}_{2}\right) \mathrm{O}_{22}(\mathrm{OH})_{2}\right]$, and muscovite $\left[\mathrm{KAl}_{2}\left(\mathrm{Si}_{3} \mathrm{Al}\right) \mathrm{O}_{10}(\mathrm{OH}, \mathrm{F})_{2}\right]$. Calcite $\left(\mathrm{CaCO}_{3(\mathrm{~S})}\right)$ was also detected by the XRD as a minor component and inorganic carbon has been quantified (see below).

The air-dried composite sediment (referred to as Hanford Silt Composite, HSC) was split into two portions with a two-way splitter. One portion was stored as the originally composited sample (hereafter referred to as original HSC) and the other was separated into a sand fraction and a finer sized fraction (hereafter referred to as the HSC silt/clay fraction) by suspending the original HSC in deionized water and wet-sieving through a $53 \mu \mathrm{m}$ mesh. The size fractions were air-dried or further treated to remove specific mineralogical components before further splitting for use in U(VI) adsorption experiments.

Pure calcite powder was used as a model compound to study U(VI) adsorption to carbonate minerals. Calcite crystals (rhombic cleavage, Sargent-Welch Scientific, Buffalo Grove, IL) were pulverized to a fine powder $(<200 \mu \mathrm{m})$ with a Shatterbox (Model 8511, Spex Industries Inc., NJ).

Sediment Treatments. For the removal of carbonate minerals, one portion of the HSC silt/clay fraction was treated with a $1 \mathrm{~mol} / \mathrm{L}$ sodium acetate solution at $\mathrm{pH} 5.0$ (adjusted with acetic acid). The treatment followed a procedure described by Zachara et al. (25), but with minor modification as described in Supporting Information (SI). The remaining materials after treatment (hereafter referred to as carbonate-free HSC silt/clay) were air-dried, homogenized, and split into two fractions, one of which was used directly for $\mathrm{U}(\mathrm{VI})$ adsorption experiments and the other of which was further treated to remove iron (hydr)oxides.

Iron (hydr)oxide-extracted sediment was prepared by chemical treatment of the carbonatefree silt/clay with a dithionite-citrate-bicarbonate (DCB) solution (26). Details of the DCB extraction can be found in SI.

Electrolytes. Calcite-saturated and $\mathrm{Ca}^{2+}$-free electrolyte solutions were used in the study of $\mathrm{U}(\mathrm{VI})$ adsorption. $\mathrm{Ca}^{2+}$-free solutions with $\mathrm{pH}$ ranging from 6 to 10 and ionic strength $(\mathrm{I})=0.05 \mathrm{~mol} / \mathrm{L}$ were prepared by appropriate additions of $\mathrm{Na}_{2} \mathrm{CO}_{3}-\mathrm{NaHCO}_{3}$, $\mathrm{NaNO}_{3}, \mathrm{HNO}_{3}$ or $\mathrm{NaOH}$ and were maintained in equilibrium with atmospheric $\mathrm{CO}_{2(\mathrm{~g})}$ by bubbling with air. Calcite-saturated electrolyte solutions in the $\mathrm{pH}$ range of $\sim 7.2$ to 10 were also made at $\mathrm{I}=0.05 \mathrm{~mol} / \mathrm{L}$ by mixing appropriate $\mathrm{Ca}^{2+}$-free electrolyte solutions with excess calcite powder $\left(\mathrm{CaCO}_{3(\mathrm{~S})}\right)$ and allowing the resulting suspensions to equilibrate for 3 days with atmospheric $\mathrm{CO}_{2(\mathrm{~g})}$ (27). The calcite-equilibrated solutions had stable $\mathrm{pH}$ and were filtered through a $0.2 \mu \mathrm{m}$ membrane filter to remove solid-phase calcite before use in adsorption experiments. 
U(VI) Adsorption. U(VI) batch adsorption experiments were conducted in 5-mL or 10-mL polyethylene centrifuge tubes at a solid/liquid ratio of $100 \mathrm{~g} / \mathrm{L}$. Preliminary experiments with various solid/liquid ratios (10 to $500 \mathrm{~g} / \mathrm{L})$ at $\mathrm{pH} 8.4$ indicated that $\mathrm{U}(\mathrm{VI})$ adsorption increased with increasing solid/liquid ratio in a manner that was consistent with the soil-water distribution coefficient $\left(\mathrm{K}_{\mathrm{d}}\right)$ and independent of the solid/liquid ratio. A ratio of $100 \mathrm{~g} / \mathrm{L}$ was selected based on a criterion of achieving a supernatant U(VI) concentration that was sufficient for measurement while still maintaining measurable amounts of uptake. Final uptake from solution was in the range of $20 \%$ to $80 \%$ for most experiments. Preliminary kinetic experiments conducted at $\mathrm{pH} 8.4$ up to 72 hours indicated that the extent of U(VI) adsorption reached a stable plateau (taken to represent equilibrium) within 30 minutes. Details of the kinetic results may be found in SI (Figure S-1). All subsequent sorption experiments were conducted with 72 hours of equilibration for consistency with preliminary studies that had been conducted for that duration.

For all experiments, the solid samples were equilibrated with either calcitesaturated or $\mathrm{Ca}^{2+}$-free electrolyte solutions prior to addition of U(VI). The solid suspensions were continuously mixed by end-over-end rotation of sorption vessels at 45 rpm for 3 days (Model 099A RD4512, Glas-Col Rotator Co., Terre Haute, IN) and centrifuged at $2100 \mathrm{~g}$ for 30 minutes, after which the supernatants were decanted and replaced with fresh calcite-saturated or $\mathrm{Ca}^{2+}$-free solution and the process repeated. After three such equilibration cycles, stable $\mathrm{pH}$ values were observed in all of the test suspensions. For the fourth replacement, the amount of remaining supernatant was gravimetrically determined and the samples then spiked with an appropriate volume of clean electrolyte solution and a small volume $(\sim 50 \mu \mathrm{L}$ to $100 \mu \mathrm{L})$ of concentrated $\mathrm{UO}_{2}\left(\mathrm{NO}_{3}\right)_{2}$ stock solution as needed to achieve the desired initial [U(VI)]. A small volume of $\mathrm{NaOH}$ solution was added to neutralize the acidity introduced by the U(VI) stock solution, which was kept at $\mathrm{pH} \approx 1.5$ to avoid precipitation of solids (such as schoepite). The estimated volume error from addition of $\mathrm{U}(\mathrm{VI})$ stock and $\mathrm{NaOH}$ solutions was less than $1 \%$. The U(VI)-spiked tubes were equilibrated for three days on the rotator shaker and kept in equilibrium with atmospheric $\mathrm{CO}_{2}$ by opening the tube caps frequently and replacing the headspace ( $\sim 3$ to $5 \mathrm{~mL}$ ) with fresh air. After equilibration, the suspensions were centrifuged at $2100 \mathrm{~g}$ for 30 minutes and supernatants were measured for $\mathrm{pH}$ and aqueous U(VI) concentration. The adsorbed U(VI) was calculated as the difference between total added U(VI) and equilibrium aqueous U(VI). All experiments were conducted with duplicate samples. At the end of each adsorption experiment, U(VI) desorption was investigated by adding fresh U(VI)-free, calcite-saturated solution. After 3 -days allotted to the desorption, U(VI) in the supernatant was measured. These results suggest that the U(VI) adsorption onto untreated silt/clay fraction is reasonably reversible. (See Figure S-2 and associated discussion in SI.)

Control experiments at $\mathrm{pH} 8.4$ were used to quantify background U(VI) concentration in electrolytes and soils, and U(VI) losses to tube walls. Both effects were negligible -- see SI.

Measurements. Total and organic carbon contents in the sediment were measured by a coulometric analysis of $\mathrm{CO}_{2}$ following high temperature combustion (combustion furnace: CM5030; $\mathrm{CO}_{2}$ coulometer: Model 5012, UIC Coulometrics Inc., IL). Prior to the measurement of total organic carbon, the sediment samples were treated with $1 \mathrm{~mol} / \mathrm{L}$ 
$\mathrm{HCl}$ to remove inorganic carbonate minerals and dried at $80^{\circ} \mathrm{C}$. The difference between the total and organic carbon contents was reported as inorganic carbon. The iron (hydr)oxide content was determined using a citrate-dithionite extraction (28).

Aqueous U(VI) concentration was measured with a kinetic phosphorescence analyzer (KPA) (KPA-11, Chemcheck Instr. Inc., Richland, WA). For the KPA analysis, $\mathrm{U}(\mathrm{VI})$ samples were acidified to about $\mathrm{pH}=1$ prior to analysis using 0.2 to $1.0 \mathrm{~mol} / \mathrm{L}$ $\mathrm{HNO}_{3}$ solutions. Some samples were diluted with enough $0.1 \mathrm{~mol} / \mathrm{L} \mathrm{HNO}_{3}$ to decrease the Ca concentration below $10^{-3} \mathrm{~mol} / \mathrm{L}$ as necessary to minimize its interference in U(VI) measurement (29). With these treatments, the effective KPA detection limit was $0.1 \mu \mathrm{g} / \mathrm{L}$. pH was measured using a combination electrode (Model 13-620-530, Fisher Scientific, $\mathrm{NJ})$.

LIFS Analysis. Laser-induced fluorescence spectra (LIFS) of aqueous samples in calcite-saturated or $\mathrm{Ca}^{2+}$-free solutions were recorded from 450 to $600 \mathrm{~nm}$ at near liquid helium temperature (LHeT $=6 \pm 1 \mathrm{~K}$ ) to determine aqueous U(VI) speciation. Details of the LIFS analysis are described in SI.

\section{Results and Discussion}

Solids Characterization. The HSC sediment was found to consist of roughly $31 \%$ sand $(>53 \mu \mathrm{m}), 61 \%$ silt $(2-53 \mu \mathrm{m})$ and $6 \%$ clay $(<2 \mu \mathrm{m})$ by weight. Total and organic carbon contents in the original HSC were found to be 3.6 and $0.57 \mathrm{mg} / \mathrm{g}$, respectively, implying $3.0 \mathrm{mg} / \mathrm{g}$ of inorganic carbon, or $0.025 \mathrm{~g} / \mathrm{g}$ as $\mathrm{CaCO}_{3(\mathrm{~S})}$. Total and organic carbon contents in the untreated HSC silt/clay fraction $(<53 \mu \mathrm{m})$ were 4.1 and $0.51 \mathrm{mg} / \mathrm{g}$, respectively, implying an inorganic carbon content of $3.6 \mathrm{mg} / \mathrm{g}$, or $0.030 \mathrm{~g} / \mathrm{g}$ as $\mathrm{CaCO}_{3(\mathrm{~S})}$. For the sand fraction, the total and organic carbon contents were $2.3 \mathrm{mg} / \mathrm{g}$ and $0.74 \mathrm{mg} / \mathrm{g}$, respectively, implying $1.6 \mathrm{mg} / \mathrm{g}$ of inorganic carbon, or $0.013 \mathrm{~g} / \mathrm{g}$ as $\mathrm{CaCO}_{3(\mathrm{~S})}$. The inorganic carbon content remaining in the treated silt/clay fraction was below the detection limit. Iron (hydr)oxides were found to be less than $1 \%$ by mass in the carbonate-free silt/clay size fraction.

U(VI) Adsorption and the Role of Carbonate Minerals. U(VI) adsorption isotherms are shown in Figure 1a for four materials under conditions of identical water chemistry that include calcite-saturated suspensions at ambient $\mathrm{P}_{\mathrm{CO} 2}$, constant ionic strength $(0.05 \mathrm{~mol} / \mathrm{L})$, and $\mathrm{pH}=8.4( \pm 0.1)$. Isotherms for all four materials (original HSC; HSC silt/clay, carbonate-free HSC silt/clay, and pure calcite) are nonlinear overall, with fitted Freundlich exponents between 0.80 and 0.88. (See Table S-2 in SI for details.) Interestingly, all samples except the carbonate-free HSC silt/clay (solid triangles) show substantially greater isotherm linearity at $[\mathrm{U}(\mathrm{VI})]<\sim 0.3 \mu \mathrm{mol} / \mathrm{L}$. (A linear relation - i.e., $\mathrm{S}=\mathrm{K}_{\mathrm{f}} \mathrm{C}-$ is evidenced by isotherm slopes approaching 1.0 on the log-log plot of Figure 1a.). U(VI) adsorption to the pure calcite was approximately the same as for the HSC silt/clay fraction $\left(\mathrm{K}_{d}\right.$ value at $\mathrm{C}_{\mathrm{e}}$ of $1 \mu \mathrm{mol} / \mathrm{L}=16 \mathrm{~mL} / \mathrm{g}$ for both materials; Table $\left.\mathrm{S}-2\right)$, and adsorption to both of these was slightly higher than to the original HSC $\left(\mathrm{K}_{d}\right.$ value at $\mathrm{C}_{\mathrm{e}}$ of $1 \mu \mathrm{mol} / \mathrm{L}=14 \mathrm{~mL} / \mathrm{g}$; Table $\left.\mathrm{S}-2\right)$. These results implied that calcite could serve as a mineral component for U(VI) adsorption in this sediment. Removal of the minor (only $\sim 3 \%$ ) mass fraction of carbonate minerals was found, however, to cause about $50 \%$ increase in U(VI) adsorption in the HSC silt/clay fraction relative to untreated samples of this same material $\left(\mathrm{K}_{\mathrm{d}}\right.$ value at $\mathrm{C}_{\mathrm{e}}$ of $1 \mu \mathrm{mol} / \mathrm{L}=24 \mathrm{~mL} / \mathrm{g}$ for treated $\mathrm{vs} 16 \mathrm{~mL} / \mathrm{g}$ for 
untreated; Table S-2). The extent of increase cannot be explained by mass additivity relations, even if sorption to the removed minerals was negligible. The degree of nonadditivity is of course even more extensive if the removed carbonates are assumed to sorb U(VI) in a similar matter as pure calcite. In either case, these results indicate that U(VI) adsorption to underlying minerals in the HSC silt/clay fraction was stronger than adsorption to exposed mineral surfaces in untreated samples of the same material. We speculate that the carbonate minerals existed as cementing and/or surface-coating phases $(17,18)$ that block U(VI) access to higher affinity sites on these silts and clays.

Figure $1 \mathrm{~b}$ shows $\mathrm{U}(\mathrm{VI})$ adsorption from calcite pre-saturated solutions of fixed initial U(VI) concentration $(1.2 \mu \mathrm{mol} / \mathrm{L})$ to both the untreated and acetic-acid-treated (carbonate-free) silt/clay fractions. As evident from this figure, U(VI) adsorption to both fractions was maximum at $\mathrm{pH}$ 8.4. As explained in the next section, the declining sorption at circumneutral $\mathrm{pH}$ reflects the effects of calcium on U(VI) speciation. For purposes of current discussion (comparisons among solids from solutions of essentially identical aqueous chemistry), we note that removal of carbonate minerals from the HSC silt/clay led to increased U(VI) adsorption at all $\mathrm{pH}$ values above 7.2, and that the largest increase $(\sim 20 \%)$ was observed in the $\mathrm{pH}$ range of 8.2 to 8.8 . Thus, the surfaces that were exposed by treatment apparently have higher affinity for U(VI) than the removed carbonate mineral surfaces over a wide range of $\mathrm{pH}$.

Influence of Aqueous $\mathrm{Ca}^{2+}$. Figure 2a compares U(VI) adsorption onto acid-treated (carbonate-free) HSC silt/clay as a function of $\mathrm{pH}$, using electrolyte solutions of equivalent $\mathrm{P}_{\mathrm{CO} 2}$ and ionic strength but with (solid triangles) or without (open triangles) solution pre-saturated with calcite. Below $\mathrm{pH} 8.4, \mathrm{U}(\mathrm{VI})$ adsorption was substantially lower for the systems using calcite pre-saturated solutions than in the $\mathrm{Ca}^{2+}$-free systems (Figure 2a). Whereas adsorption from the calcite-saturated electrolyte solution shows steadily decreasing sorption as $\mathrm{pH}$ drops below 8.4 (Figure 2a), the fraction of U(VI) adsorbed from $\mathrm{Ca}^{2+}$-free electrolyte is nearly $100 \%$ for all $\mathrm{pH}$ below 7.2 and is $>80 \%$ up through $\mathrm{pH}$ 8.4. This behavior is similar to that typically reported in the literature for $\mathrm{U}(\mathrm{VI})$ adsorption to clean minerals as a function of $\mathrm{pH}$ and in the presence of aqueous carbonate but not calcium (e.g., 30,31). Above $\mathrm{pH} 8.4$, the U(VI) adsorption in the two systems was almost identical. Also, comparison among the two open-symbol plots in Figure 2a (upright and upside-down triangles) shows that removal of iron (hydr)oxides had no effect on the U(VI) adsorption. Given that iron (hydr)oxides are in low concentration in this material $(<1 \%)$, it is unlikely that these minerals play an important role in this system. It is more likely that the higher affinity sites were associated with the edges of phyllosilicate minerals in the sediments, which can strongly complex with aqueous U(VI) (4-6).

Figure $2 \mathrm{~b}$ shows that results with the untreated (carbonate-containing) silt/clay fraction in initially calcite-saturated solutions (solid diamonds) are similar to those in initially $\mathrm{Ca}^{2+}$-free solutions (open diamonds). These results suggest that dissolved calcium from the untreated silt/clay fraction can affect sorption in a similar manner as that brought into solution through calcite pre-saturation. In fact, the amount of carbonate minerals in this untreated HSC silt/clay were calculated to be more than sufficient to provide solution saturation with respect to calcite during U(VI) adsorption equilibration, even for cases where the added water was initially free of calcium. A comparison of the 
dissolved calcium concentrations in these systems as obtained from calculations (based on known $\mathrm{pH}, \mathrm{P}_{\mathrm{CO} 2}$, and calcite solubility) and measurement (by ICP-OES) is presented in SI.

Overall, the results show that those systems without $\mathrm{Ca}^{2+}$ in solution had much stronger $\mathrm{U}(\mathrm{VI})$ sorption in the $\mathrm{pH}$ range of 7.2 to 8.4. The results are best understood in conjunction with our results for the calculated and observed U(VI) speciation, as described below.

U(VI) Speciation Calculations and Implications for Sorption. Aqueous U(VI) speciation in both calcite-saturated (Figure 3) and $\mathrm{Ca}^{2+}$-free suspensions (Figure S-3 of SI) were calculated using FITEQL 4.0 (32) with a database assembled by the authors from the literature $(21,33)$. In the calcite-saturated sorption suspensions, a ternary species $\left[\mathrm{Ca}_{2} \mathrm{UO}_{2}\left(\mathrm{CO}_{3}\right)_{3}{ }^{0}(\mathrm{aq})\right]$ was calculated to be the dominant species at $\mathrm{pH}$ below 8.4 (Figure 3 ). This is in contrast to the situation in $\mathrm{Ca}^{2+}$-free suspensions $\left(\mathrm{Ca}^{2+}\right.$-free electrolyte with carbonate-free silt/clay) where $\left(\mathrm{UO}_{2}\right)_{2}(\mathrm{OH})_{3} \mathrm{CO}_{3}{ }^{-}, \mathrm{UO}_{2}\left(\mathrm{CO}_{3}\right)_{2}{ }^{2-}$ and $\mathrm{UO}_{2}\left(\mathrm{CO}_{3}\right)_{3}{ }^{4-}$ were calculated to be the dominant species at $\mathrm{pH} 6.4$ to 10. (See Figure S-3 in SI and Figure 2a in Ref.30.) Above $\mathrm{pH} 8.4, \mathrm{UO}_{2}\left(\mathrm{CO}_{3}\right)_{3}{ }^{4-}$ was calculated to be dominant in both calcitesaturated and calcium-free systems.

Given that the aqueous $\mathrm{Ca}_{2} \mathrm{UO}_{2}\left(\mathrm{CO}_{3}\right)_{3}{ }^{0}$ complex is expected in the calcite-saturated supernatants either for untreated HSC silt/clay or for carbonate-free silt/clay, the differences of $\mathrm{U}(\mathrm{VI})$ adsorption from $\mathrm{pH} 7.2$ to 8.4 (Figures $2 \mathrm{a}$ and $2 \mathrm{~b}$ ) are most likely due to the dominant presence of $\mathrm{Ca}_{2} \mathrm{UO}_{2}\left(\mathrm{CO}_{3}\right)_{3}{ }^{0}$ (aq) (or closely related species) at $\mathrm{pH}<8.4$ in the calcium-containing systems. By contrast, the similarity of results at $\mathrm{pH}>8.4$ for all systems (Figures $1 \mathrm{~b}, 2 \mathrm{a}$, and $2 \mathrm{~b}$ ) is in agreement with calculations that suggest the dominance of a single species $\left(\mathrm{UO}_{2}\left(\mathrm{CO}_{3}\right)_{3}{ }^{4-}\right)$ at high-pH in all of the systems. Some of these predicted speciation differences can also be directly measured through LIFS, as described below.

U(VI) Speciation Measurements (LIFS). For samples with higher concentrations of dissolved calcium, the LIFS analysis of the sorption suspension supernatants showed moderate to intense U(VI) fluorescence spectra at LHeT with well-resolved vibronic bands with spectral origins at $\sim 480 \mathrm{~nm}$ (Figure 4 and Table 1). By contrast, the samples containing calcium-free suspensions (carbonate-free HSC silt/clay and $\mathrm{Ca}^{2+}$-free electrolyte) showed weak and noisy LIFS spectra because U(VI) was primarily partitioned to the solid phase (Figure 2a). The well-resolved LIFS spectra (Figure 4) possess the basic structure of uranyl-tricarbonate in which the three carbonate groups are coordinated along the equatorial plane of the uranyl ion as bidentate ligands (34-37). A careful examination of the LIFS spectra revealed that for the suspension supernatants with calcite-saturated electrolytes at circumneutral pHs (shown as traces 4 and 8 at $\mathrm{pH}$ 7.3 in Figure 4 and Table 1) the spectral positions were shifted $\sim 2 \mathrm{~nm}$ to longer wavelength as compared to those at higher $\mathrm{pH}$ (shown as traces 5 and 7 at $\mathrm{pH} 8.3$ and 8.5 in Figure 4 and Table 1). Comparisons of these spectral features with those of aqueous species $\mathrm{Ca}_{2} \mathrm{UO}_{2}\left(\mathrm{CO}_{3}\right)_{3}{ }^{0}$ (aq) and $\mathrm{UO}_{2}\left(\mathrm{CO}_{3}\right)_{3}{ }^{4-}$ (traces 2 and 3, respectively, in Figure 4) suggest that $\mathrm{Ca}_{2} \mathrm{UO}_{2}\left(\mathrm{CO}_{3}\right)_{3}{ }^{0}{ }_{(\mathrm{aq})}$ dominated aqueous uranyl speciation in the calcitesaturated suspensions at circumneutral $\mathrm{pHs}$, while $\mathrm{UO}_{2}\left(\mathrm{CO}_{3}\right)_{3}{ }^{4-}$ dominated above $\mathrm{pH} 8.3$. The removal of carbonate minerals from the sediment did not alter the supernatant U(VI) speciation if the electrolyte was equilibrated with calcite - compare trace 8 (carbonatefree) to trace 4 (untreated). 
The measured U(VI) speciation was generally consistent with the calculated speciation, although noticeable differences were present. In particular, species $\mathrm{Ca}_{2} \mathrm{UO}_{2}\left(\mathrm{CO}_{3}\right)_{3}{ }^{0}$ (aq) was calculated to dominate up to $\mathrm{pH} 8.4$ (Figure 3), while the LIFS spectra indicated that species $\mathrm{UO}_{2}\left(\mathrm{CO}_{3}\right)_{3}{ }^{4-}$ dominated at $\mathrm{pH} 8.3$ (Figure 4 and Table 1). There was likely a more gradual transition of $\mathrm{U}(\mathrm{VI})$ aqueous species dominance from $\mathrm{Ca}_{2} \mathrm{UO}_{2}\left(\mathrm{CO}_{3}\right)_{3}{ }^{0}$ (aq) to $\mathrm{UO}_{2}\left(\mathrm{CO}_{3}\right)_{3}{ }^{4-}$ as $\mathrm{pH}$ increased from 7.0 to 10.0 , relative to the calculated result which shows a sharp transition at $\mathrm{pH} 8.4$ (Figure 3). A stability constant of $\log \mathrm{K}=29.8$ (21) for $\mathrm{Ca}_{2} \mathrm{UO}_{2}\left(\mathrm{CO}_{3}\right)_{3}{ }^{0}$ (aq) was used in this calculation. A lower stability constant of $\log \mathrm{K}=26.8(\mathrm{I}=0.1 \mathrm{~mol} / \mathrm{L})$ has also been reported for this species (38). If an averaged value of $\log \mathrm{K}=28.3$ from these two sources is used, the calculated stability field of $\mathrm{Ca}_{2} \mathrm{UO}_{2}\left(\mathrm{CO}_{3}\right)_{3}{ }^{0}$ (aq) shifts to a lower $\mathrm{pH}$ range and is more consistent with the LIFS measurements.

In the untreated sediment suspensions with initially $\mathrm{Ca}^{2+}$-free electrolyte solution, the LIFS spectral peaks shifted only slightly toward longer wavelength in the $\mathrm{pH} 7.3$ sample (Figure 4 trace 6,) compared with those in the sample at pH 8.3 (Figure 4 trace 7). The LIFS peaks were also slightly broadened toward longer wavelength in the $\mathrm{pH} 7.3$ sample. The difference was, however, small and in both samples, the LIFS spectra were close to those of $\mathrm{UO}_{2}\left(\mathrm{CO}_{3}\right)_{3}{ }^{4-}$ (Figure 4 and Table 1$)$. These LIFS results are somewhat in contrast with expectations, based on sorption results and speciation calculations. The slight LIFS peak shift and broadening toward longer wavelength in the $\mathrm{pH} 7.3$ sample may indicate the presence of other unknown species in the system that affect U(VI) adsorption in a similar way as $\mathrm{Ca}_{2} \mathrm{UO}_{2}\left(\mathrm{CO}_{3}\right)_{3}{ }^{0}$ (aq). The measurement of stability constants for species $\mathrm{Ca}_{2} \mathrm{UO}_{2}\left(\mathrm{CO}_{3}\right)_{3}{ }^{0}$ (aq) have suggested that a species $\mathrm{CaUO}_{2}\left(\mathrm{CO}_{3}\right)_{3}{ }^{2-}$ can become increasing dominant at a decreasing ratio of $\mathrm{Ca}^{2+}$ to $\mathrm{U}(\mathrm{VI})$ (21). Unfortunately, further evaluation of these results is limited by a still incomplete understanding of the thermodynamics and LIFS spectra for $\mathrm{CaUO}_{2}\left(\mathrm{CO}_{3}\right)_{3}{ }^{2-}$ and other potential species in the calcium-uranyl-carbonate system.

Size Fraction Additivity. U(VI) was adsorbed to both silt/clay and sand size fractions under the studied $\mathrm{pH}$ range (Figure 5). Below $\mathrm{pH} 9, \mathrm{U}(\mathrm{VI})$ adsorbed more strongly to silt/clay than to the sand fraction, on a unit mass basis. Above $\mathrm{pH} \mathrm{9,} \mathrm{however,}$ the U(VI) adsorption was stronger to the sand fraction. A U(VI) adsorption peak near $\mathrm{pH}$ 8.4 was again observed in the original HSC sediment and its size fractions. U(VI) adsorption to the original HSC was approximately between those to the silt/clay and sand fractions and was close to the amount calculated by a linear additivity approach (solid line). The calculation was made by a linear, mass-weighted combination of adsorbed $\mathrm{U}(\mathrm{VI})$ in the sand and silt/clay fractions - that is, $K_{\mathrm{d}(\mathrm{HSC})}=f_{\text {silt/clay }} K_{\mathrm{d}(\text { silt/clay) }}+f_{\text {sand }} K_{\mathrm{d}(\mathrm{sand}) \text {, }}$ where $f_{\text {silt/clay }}$ and $f_{\text {sand }}$ are the mass fractions (\%wt) of the silt/clay and sand in the original HSC, respectively; $K_{\mathrm{d}(\text { silt/clay) }}$ and $K_{\mathrm{d}(\text { sand) }}$ are the adsorbed U(VI) distribution coefficients $(\mathrm{mL} / \mathrm{g})$ in the suspensions of silt/clay and sand fractions, respectively; and $K_{d(\mathrm{HSC})}$ is the overall distribution coefficient $(\mathrm{mL} / \mathrm{g})$ in the original HSC system. The relationship between adsorption percentage $\left[\% \mathrm{U}(\mathrm{VI})_{\mathrm{sb}}\right]$ and distribution coefficient $\left(K_{\mathrm{d}}, \mathrm{mL} / \mathrm{g}\right)$ is given by the equation: $\% \mathrm{U}(\mathrm{VI})_{\mathrm{sb}}=K_{\mathrm{d}}\left(K_{\mathrm{d}}+\mathrm{V} / \mathrm{m}\right)$, where $\mathrm{V} / \mathrm{m}$ is the ratio of solution volume to solid mass, which is a constant in this study $(10 \mathrm{~mL} / \mathrm{g})$.

Component Additivity. With the component additivity (CA) approach (39-42), $\mathrm{U}(\mathrm{VI})$ adsorption to the mineral assemblage or sediment would be the simple mass- 
weighted sum of mass-based U(VI) adsorption estimates for the individual mineral components. Our results clearly indicate, however, that such a CA approach is not applicable to the consideration of carbonate minerals in the HSC silt/clay materials. Although carbonate minerals are minor ( $\sim 3 \%)$ components of the silt/clay material and calcite can individually adsorb U(VI), our results show that carbonate removal from this material caused substantial increases in U(VI) adsorption ( $50 \%)$ (Figure 1). Thus, a more complex and mechanistically rigorous CA approach would be required, perhaps as based on a more complete understanding of the variety of exposed surfaces and their relative contributions to sorption. In the absence of such understanding, however, it is necessary to directly characterize U(VI) adsorption to the actual mineral assemblages as they exist in-situ.

Expected Effects on U(VI) Transport. Overall, our results imply that the presence of calcite (at concentrations present in the original HSC solids) may act to increase U(VI) mobility in the Hanford subsurface because the calcite can (1) prevent access to U(VI) adsorption onto higher energy adsorption sites in the silt/clay fraction; and (2) provide a source of calcium and carbonate to water that promotes the formation of a ternary uranyl aqueous species $\mathrm{Ca}_{2} \mathrm{UO}_{2}\left(\mathrm{CO}_{3}\right)_{3}{ }^{0}$ (aq), which effectively competes with surface sites for the complexation of U(VI). Note that both effects will cause increased U(VI) mobility at circumneutral to mildly alkaline subsurface environments. Thus, the assessment of $U$ reactive transport at this site or others with similar geochemical conditions will need to consider the influence of calcite and carbonate minerals as U(VI) sorbents, as inhibitors of U(VI) access to potentially higher affinity U(VI) adsorption sites of other minerals, and as contributors of dissolved divalent cations and carbonate that can affect $\mathrm{U}(\mathrm{VI})$ aqueous speciation and adsorption.

\section{Acknowledgements}

The research described in this manuscript was supported by the Environmental Management Science Program of the office of Science, U.S. Department of Energy under contract DE-FG07-02ER63498. A portion of the research was performed at the W. R. Wiley Environmental Molecular Sciences Laboratory, a national scientific user facility sponsored by the U.S. Department of Energy's Office of Biological and Environmental Research and located at Pacific Northwest National Laboratory. PNNL is operated for the Department of Energy by Battelle. We thank Steven C. Smith at PNNL for providing the Hanford subsurface sediments.

\section{Literature Cited}

(1) Abdelouas, A.; Lutze, W.; Nuttall, E. H. Uranium contamination in the subsurface: characterization and remediation. In Uranium: Mineralogy, Geochemistry and the Environment. Reviews in Mineralogy; Burns, P. C., Finch, R., Eds., 1999; Vol. 38, pp 433-473.

(2) Riley, R. G.; Zachara, J. M.; Wobber, F. J. Chemical Contaminants on DOE Lands and Selection of Contaminant Mixtures for Subsurface Science Research; DOE/ER0547T; U.S. Department of Energy, Office of Energy Research, Washington, DC, 1992.

(3) Lindberg, J. W.; Peterson, R. E. 300-FF-5 operable unit, Chapter 1.12. In Hnaford Site Groundwater Monitoring for Fiscal Year 2003; Hartman, M. J., Morasch, L. F., 
Webber, W. D., Eds.; PNNL-14548, Pacific Northwest National Laboratory: Richland, WA, 2004.

(4) McKinley, J. P.; Zachara, J. M.; Smith, S. C.; Turner, G. D. The influence of uranyl hydrolysis and multiple site-binding reactions on adsorption of U(VI) to montmorillonite. Clays and Clay Minerals 1995, 43, 586-598.

(5) Turner, G. D.; Zachara, J. M.; McKinley, J. P.; Smith, S. C. Surface-charge properties and $\mathrm{UO}_{2}{ }^{2+}$ adsorption of a subsurface smectite. Geochim. Cosmochim. Acta 1996, 60, 3399-3414.

(6) Pabalan, R. T.; Turner, D. R. Uranium(+6) sorption on montmorillonite: Experimental and surface complexation modeling study. Aquatic Geochem. 1996, 2, 203-226.

(7) Bargar, J. R.; Reitmeyer, R.; Davis, J. A. Spectroscopic confirmation of uranium(VI) - carbonato adsorption complexes on hematitle. Environ. Sci. Technol. 1999, 33, 2481-2484.

(8) Villalobos, M.; Trotz, M. A.; Leckie, J. O. Surface complexation modeling of carbonate effects on the adsorption of $\mathrm{Cr}(\mathrm{VI}), \mathrm{Pb}(\mathrm{II})$, and $\mathrm{U}(\mathrm{VI})$ on goethite. Environ. Sci. Technol. 2001, 35, 3849-3856.

(9) Payne, T. E.; Lumpkin, G. R.; Waite, T. D. Uranium(VI) adsorption on model minerals: controlling factors and surface complexation modeling. In Adsorption of Metals by Geomedia: Variables, Mechanisms and Model Applications; Jenne, E. A., Ed.; Academic Press: San Diego, CA, 1998; pp 75-97.

(10) Wazne, M.; Korfiatis, G. P.; Meng, X. Carbonate effects on hexavalent uranium adsorption by iron oxyhydroxide. Environ. Sci. Technol. 2003, 37, 3619-3624.

(11) Greathouse, J. A.; O'Brien, R. J.; Bemis, G.; Pabalan, R. T. Molecular dynamics study of aqueous uranyl interactions with quartz (010). J. Phys. Chem. B 2002, 106, 1646-1655.

(12) Prikryl, J. D.; Jain, A.; Turner, D. R.; Pabalan, R. T. Uranium(VI) sorption behavior on silicate mineral mixtures. J. Contam. Hydrol. 2001, 47, 241-253.

(13) Van Cappellen, P.; Charlet, L.; Stumm, W.; Wersin, P. A surface complexation model of the carbonate mineral-aqueous solution interface. Geochim. Cosmochim. Acta 1993, 57, 3505-3518.

(14) Davis, J. A.; Fuller, C. C.; Cook, A. D. A model for trace metal sorption processes at calcite surface: Adsorption of $\mathrm{Cd}^{2+}$ and subsequent solid solution formation. Geochim. Cosmochim. Acta 1987, 51, 1477-1490.

(15) Zachara, J. M.; Cowan, C. E.; Resch, C. T. Sorption of divalent metals on calcite. Geochim. Cosmochim. Acta 1991, 55, 1549-1562.

(16) Carroll, S. A.; Bruno, J.; Petit, J.-C.; Dran, J.-C. Interaction of U(VI), Nd, and $\mathrm{Th}(\mathrm{IV})$ at the calcite-solution interface. Radiochim. Acta 1992, 58/59, 245-252.

(17) Doner, H. E.; Lynn, W. C. Chap. 6. Carbonate, halide, sulfate, and sulfide minerals. In Minerals in Soil Environments; 2 ed.; Dixon, J. B., Weed, S. B., Eds.; Soil Science Society of American, Inc.: Madison, Wisconsin, 1989; Vol. 1, pp 279-324.

(18) Tao, Z.; Dong, W. Additivity rule and its application to the sorption of radionuclides on soils. Radiochim. Acta 2003, 91, 299-303.

(19) Liu, C.; Zachara, J. M.; Qafoku, O.; McKinley, J. P.; Heald, S. M.; Wang, Z. Dissolution of Uranyl Microprecipitates from Subsurface Sediments at Hanford Site, USA. Geochim. Cosmochim. Acta 2004, 68, 4519-4537. 
Appendix I

(20) Bernhard, G.; Geipel, G.; Reich, T.; Brendler, V.; Amayri, S.; Nitsche, H. Uranyl(VI) carbonate complex formation: Validation of the $\mathrm{Ca}_{2} \mathrm{UO}_{2}\left(\mathrm{CO}_{3}\right)_{3}(\mathrm{aq})$ species.

Radiochim. Acta 2001, 89, 511-518.

(21) Kalmykov, S. N.; Choppin, G. R. Mixed $\mathrm{Ca}^{2+} / \mathrm{UO}_{2}{ }^{2+} / \mathrm{CO}_{3}{ }^{2-}$ complex formation at different ionic strengths. Radiochim. Acta 2000, 88, 603-606.

(22) Wang, Z.; Zachara, J. M.; Gassman, P. L.; Liu, C.; Qafoku, O.; Catalano, J. G. Fluorescence spectroscopy of U(VI)-silicate and U(VI)-contaminated Hanford sediment. Geochim. Cosmochim. Acta 2005, 69, 1391-1403.

(23) Zheng, Z.; Tokunaga, T. K.; Wan, J. Influence of calcium carbonate on U(VI) sorption to soils. Environ. Sci. \& Technol. 2003, 37, 5603-5608.

(24) Serne, R.; Bjornstad, B. N.; Schaef, H. T.; Williams, B. A.; Lanigan, D. C.; Horton, D. G.; Clayton, R. E.; LeGore, V. L.; O'Hara, M. J.; Brown, C. F.; Parker, K. E.; Kutnyakov, J. N.; Serne, J. N.; Mitroshkov, A. V.; Last, G. V.; Smith, S. C.; Lindenmeier, C. W.; Zachara, J. M.; Burke, D. S. Characterization of vadose zone sediment: uncontaminated RCRA borehole core samples and composite samples.; PNNL-13757-1; Pacific Northwest National Laboratory, Richland, WA, 2002.

(25) Zachara, J. M.; Smith, S. C.; Liu, C.; McKinley, J. P.; Serne, R. J.; Gassman, P. L. Sorption of $\mathrm{Cs}^{+}$to micaceous subsurface sediments from the Hanford site, USA. Geochim. Cosmochim. Acta 2002, 66, 193-211.

(26) Mehra, O. P.; Jackson, M. L. Iron oxides removal from soils and clays by a dithionite-citrate system buffered with sodium bicarbonate.7th Natl. Conf. Clays and Clay Minerals, 1960, pp 317-327.

(27) Svensson, U.; Dreybrodt, W. Dissolution kinetics of natural calcite minerals in $\mathrm{CO}^{2}$ water systems approaching calcite equilibrium. Chem. Geol. 1992, 100, 129-145.

(28) Ross, G. J.; Wang, C. Chap.25 Extractable Al, Fe, Mn, and Si. In Soil Sampling and Methods of Analysis; Carter, M. R., Ed.; Can. Soc. Soil Sci., 1993; pp 239-246.

(29) Sowder, A. G.; Clark, S. B.; Fjeld, R. A. The effect of sample matrix quenching on the measurement of trace uranium concentrations in aqueous solutions using kinetic phosphorimetry. J. Radioanl. Nucl. Chem. 1998, 234, 257-260.

(30) Waite, T. D.; Davis, J. A.; Payne, T. E.; Waychunas, G. A.; Xu, N. Uranium(VI) adsorption to ferrihydrite: Application of a surface complexation model. Geochim. Cosmochim. Acta 1994, 58, 5465-5478.

(31) Barnett, M. O.; Jardine, P. M.; Brooks, S. C. U(VI) adsorption to heterogeneous subsurface media: Application of a surface complexation model. Environ. Sci. Technol. 2002, 36, 937-942.

(32) Herbelin, A.; Westall, J. A Computer Program for Chemical Equilibrium Constants from Experimental Data; Oregon State University, 1999.

(33) Grenthe, I.; Fuger, J.; Konings, R. J. M.; Lemire, R. J.; Muller, A. B.; Nguyen-Trung, C.; Wanner, H. Chemical Thermodynamics Vol1: Chemical Thermodynamics of Uranium; North-Holland Elsevier Science: New York, 1992.

(34) Elzinga, E. J.; Tait, C. D.; Reeder, R. J.; Rector, K. D.; Donohoe, R. J.; Morris, D. E. Spectroscopic investigation of U(VI) sorption at the calcite-water interface. Geochim. Cosmochim. Acta 2004, 68, 2437-2448.

(35) Reeder, R.; Nugent, M.; Tait, C. D.; Morris, D. E.; Heald, S. M.; Beck, K. M.; Hess, W. P.; Lanzirotti, A. Coprecipitation of uranium(VI) with calcite: XAFS, micro- 
Appendix I

XAS, and luminescence characterization. Geochimca et Cosmochimca Acta 2001, 65, 3491-3503.

(36) Wang, Z.; Zachara, J. M.; McKinley, J. P. Cryogenic laser induced U(VI) fluorescence studies of a U(VI) substituted natural calcite: implications to U(VI) speciation in contaminated Hanford sediments. Environ. Sci. \& Technol. 2005,38, 2651-2659.

(37) Wang, Z.; Zachara, J. M.; Yantasee, W.; Gassman, P. L.; Liu, C. X.; Joly, A. G. Cryogenic laser induced fluorescence characterization of U(VI) in Hanford vadose zone pore waters. Environ. Sci. \& Technol. 2004, 38, 5591-5597.

(38) Bernhard, G.; Geipel, G.; Brendler, V.; Nitsche, H. Speciation of uranium in seepage waters of a mine tailing pile studied by time-resolved laser-induced fluorescence spectroscopy (TRLFS). Radiochim. Acta 1996, 74, 87-91.

(39) Jacquier, P.; Meier, P.; Ly, J. Adsorption of radioelements on mixtures of minerals experimental study. Appl. Geochem. 2001, 16, 85-93.

(40) Honeyman, B. D. Cation and Anion Adsorption at the Oxide/Solution Interface in Systems Containing Binary Mixtures of Adsorbents: an Investigation of the Concept of Adsorptive Additivity, Stanford University, Ph.D. Thesis, 1984.

(41) Davis, J. A.; Coston, J. A.; Kent, D. B.; Fuller, C. C. Application of the surface complexation concept to complex minerals assemblages. Environ. Sci. Technol. 1998, 32, 2820-2828.

(42) Davis, J. A.; Meece, D. E.; Kohler, M.; Curtis, G. P. Approaches to surface complexation modeling of uranium(VI) adsorption on aquifer sediments. Geochim. Cosmochim. Acta 2004, 68, 3621-3641. 
Table 1. LHeT fluorescence spectral characteristics of aqueous U(VI) species after $\mathrm{U}(\mathrm{VI})$ adsorption equilibration $\left(\mathrm{P}_{\mathrm{CO} 2}=10^{-3.5}\right.$ atm and $\left.\lambda_{\mathrm{ex}}=415 \mathrm{~nm}\right)$

\begin{tabular}{|c|c|c|c|}
\hline $\begin{array}{c}\text { Sample } \\
\text { ID }^{\mathbf{a}}\end{array}$ & Sample & $\begin{array}{c}\text { Spectral } \\
\text { maxima }(\mathbf{n m})\end{array}$ & Major species \\
\hline 1 & $\mathrm{UO}_{2}^{2+b, c}$ & $\begin{array}{l}491.7,513.9, \\
538.4,563.5\end{array}$ & $\mathrm{UO}_{2}{ }^{2+}$ \\
\hline 2 & $\mathrm{Ca}_{2} \mathrm{UO}_{2}\left(\mathrm{CO}_{3}\right)_{3}{ }^{0}(\mathrm{aq}){ }^{\mathrm{b}}$ & $\begin{array}{l}480.5,501.2, \\
522.7,546.0\end{array}$ & $\mathrm{Ca}_{2} \mathrm{UO}_{2}\left(\mathrm{CO}_{3}\right)_{3}{ }_{(\mathrm{aq})}$ \\
\hline 3 & $\mathrm{UO}_{2}\left(\mathrm{CO}_{3}\right)_{3}{ }^{4-b}$ & $\begin{array}{l}\text { 479.6, 499.2, } \\
519.9,542.4\end{array}$ & $\mathrm{UO}_{2}\left(\mathrm{CO}_{3}\right)_{3}{ }^{4-}$ \\
\hline 4 & $\begin{array}{l}\text { supernatant: } \\
\text { untreated HSC silt/clay; calcite } \\
\text { pre-saturated solution, } \\
\text { pH }=7.3\end{array}$ & $\begin{array}{l}481.2,502.0 \\
521.9,545.5\end{array}$ & $\left.\mathrm{Ca}_{2} \mathrm{UO}_{2}\left(\mathrm{CO}_{3}\right)_{3}{ }_{(\mathrm{aq})}\right)$ \\
\hline 5 & $\begin{array}{l}\text { supernatant: } \\
\text { untreated HSC silt/clay; calcite } \\
\text { pre-saturated solution, } \\
\text { pH }=8.3\end{array}$ & $\begin{array}{l}\text { 478.7, 499.0, } \\
519.7,543.3\end{array}$ & $\mathrm{UO}_{2}\left(\mathrm{CO}_{3}\right)_{3}{ }^{4-}$ \\
\hline 6 & $\begin{array}{l}\text { supernatant: } \\
\text { untreated } \mathrm{HSC} \text { silt/clay; } \\
\text { initially } \mathrm{Ca}^{2+} \text {-free solution, } \\
\mathrm{pH}=7.3\end{array}$ & $\begin{array}{l}478.7,499.0 \\
520.2,543.0\end{array}$ & $\mathrm{UO}_{2}\left(\mathrm{CO}_{3}\right)_{3}{ }^{4-}$ \\
\hline 7 & $\begin{array}{l}\text { supernatant: } \\
\text { untreated } \mathrm{HSC} \text { silt/clay; } \\
\text { initially } \mathrm{Ca}^{2+} \text {-free solution, } \\
\mathrm{pH}=8.5\end{array}$ & $\begin{array}{l}478.4,499.0 \\
520.8,543.0\end{array}$ & $\mathrm{UO}_{2}\left(\mathrm{CO}_{3}\right)_{3}{ }^{4-}$ \\
\hline 8 & $\begin{array}{l}\text { supernatant: } \\
\text { carbonate-free HSC silt/clay; } \\
\text { calcite pre-saturated solution, } \\
\mathrm{pH}=7.3\end{array}$ & $\begin{array}{l}\text { 480.6, 500.6, } \\
522.2,544.9\end{array}$ & $\mathrm{Ca}_{2} \mathrm{UO}_{2}\left(\mathrm{CO}_{3}\right)_{3}{ }_{(\mathrm{aq})}$ \\
\hline 9 & $\begin{array}{l}\text { supernatant: } \\
\text { carbonate-free HSC silt/clay; } \\
\text { initially } \mathrm{Ca}^{2+} \text {-free solution, } \\
\mathrm{pH}=7.3\end{array}$ & $\begin{array}{l}478.4,500.1, \\
521.3,544.7\end{array}$ & $\mathrm{UO}_{2}\left(\mathrm{CO}_{3}\right)_{3}{ }^{4-}$ \\
\hline
\end{tabular}

${ }^{\mathrm{a}}$ Trace number in Figure 4.

${ }^{\mathrm{b}}$ Data from reference (37).

${ }^{\mathrm{c}}$ Uranyl exists as the $\mathrm{UO}_{2}{ }^{2+}$ ion and/or its complexes with nitrate. 


\section{Captions}

Figure 1. a) U(VI) sorption isotherms for four materials in calcite pre-saturated solutions at $\mathrm{pH}=8.4 \pm 0.1$ and $\mathrm{P}_{\mathrm{CO} 2}=10^{-3.5} \mathrm{~atm}: \quad \boldsymbol{\Delta}=$ carbonate-free $\mathrm{HSC}$ silt $/$ clay;

$\checkmark=$ untreated HSC silt/clay; $\mathbf{X}=$ pure calcite; $\mathrm{O}=$ original HSC. (Initial $[\mathrm{U}(\mathrm{VI})]$ ranged from $1.0 \times 10^{-7}$ to $1.0 \times 10^{-5} \mathrm{~mol} / \mathrm{L}$, solid/solution ratio $=100 \mathrm{~g} / \mathrm{L}, \mathrm{I}=0.05 \mathrm{~mol} / \mathrm{L}\left(\mathrm{NaNO}_{3}\right)$, and temp. $=22.5^{\circ} \mathrm{C}$.)

b.) $\mathrm{U}(\mathrm{VI})$ sorption as a function of $\mathrm{pH}$ in calcite pre-saturated solutions at $\mathrm{P}_{\mathrm{CO} 2}=10^{-3.5}$

atm: $\bullet=$ untreated HSC silt/clay; $\mathbf{\Lambda}=$ carbonate-free silt/clay (Initial $[\mathrm{U}(\mathrm{VI})]=1.2 \times 10^{-}$

${ }^{6} \mathrm{~mol} / \mathrm{L}$, solid/solution ratio $=100 \mathrm{~g} / \mathrm{L}, \mathrm{I}=0.05 \mathrm{~mol} / \mathrm{L}\left(\mathrm{NaNO}_{3}\right)$, and temp. $\left.=22.5{ }^{\circ} \mathrm{C}\right)$.

Figure 2. U(VI) sorption as a function of $\mathrm{pH}$ in five systems:

a) Three sorption systems with acid washed solids:

$\boldsymbol{\Delta}=$ carbonate-free HSC silt/clay in calcite-pre-saturated solution; $\triangle=$ carbonate-free HSC silt/clay in $\mathrm{Ca}^{2+}$-free solution; $\nabla=$ both carbonate- and iron-(hydr)oxide-free silt/clay in $\mathrm{Ca}^{2+}$-free solution. (Initial $[\mathrm{U}(\mathrm{VI})]=1.2 \times 10^{-6} \mathrm{~mol} / \mathrm{L}$, solid/solution ratio $=100$ $\mathrm{g} / \mathrm{L}, \mathrm{I}=0.05 \mathrm{~mol} / \mathrm{L}\left(\mathrm{NaNO}_{3}\right), \mathrm{P}_{\mathrm{CO} 2}=10^{-3.5} \mathrm{~atm}$, and temp. $\left.=22.5^{\circ} \mathrm{C}\right)$. Note that only the systems with open symbols are calcium free.

b) Two sorption systems with untreated HSC silt/clay:

$\checkmark=$ untreated HSC silt/clay with calcite pre-saturated solution; $\diamond=$ untreated HSC silt/clay with initially $\mathrm{Ca}^{2+}$-free solution (Initial $[\mathrm{U}(\mathrm{VI})]=1.2 \times 10^{-6} \mathrm{~mol} / \mathrm{L}$, solid/solution ratio $=100 \mathrm{~g} / \mathrm{L}, \mathrm{I}=0.05 \mathrm{~mol} / \mathrm{L}\left(\mathrm{NaNO}_{3}\right), \mathrm{P}_{\mathrm{CO} 2}=10^{-3.5} \mathrm{~atm}$., and temp. $\left.=22.5^{\circ} \mathrm{C}\right)$. Note that neither system is calcium free at equilibrium conditions.

Figure 3. $\mathrm{U}(\mathrm{VI})$ speciation in calcite pre-saturated solution at $\mathrm{P}_{\mathrm{CO} 2}=10^{-3.5} \mathrm{~atm},([\mathrm{U}(\mathrm{VI})]$ $=1.0 \times 10^{-6} \mathrm{~mol} / \mathrm{L}, \mathrm{I}=0.05 \mathrm{~mol} / \mathrm{L}\left(\mathrm{NaNO}_{3}\right)$, and temp. $\left.=25^{\circ} \mathrm{C}\right)$. The complexation constants of all species are from Grenthe et al, 1992 and Kalmykov and Choppin, 2000 $(21,33)$.

Figure 4. LHeT fluorescence spectra at $\lambda_{\mathrm{ex}}=415 \mathrm{~nm}$ for: 1) standard solution of aqueous $\mathrm{UO}_{2}{ }_{4-}^{2+}{ }_{(\mathrm{aq}} ;$; $)$ standard solution of $\left.\mathrm{Ca}_{2} \mathrm{UO}_{2}\left(\mathrm{CO}_{3}\right)_{3}{ }^{0}(\mathrm{aq}) ; 3\right)$ standard solution of $\left(\mathrm{UO}_{2}\right)\left(\mathrm{CO}_{3}\right)_{3}{ }^{4-}$ (aq); ; and samples of the following six sorption vessel supernatants (centrates): 4) after contact with untreated HSC silt/clay using calcite pre-saturated solution, $\left.[\mathrm{U}(\mathrm{VI})]=7.5 \times 10^{-7} \mathrm{~mol} / \mathrm{L}, \mathrm{pH}=7.3 ; 5\right)$ after contact with untreated HSC silt/clay using calcite pre-saturated solution, $\left.[\mathrm{U}(\mathrm{VI})]=4.6 \times 10^{-7} \mathrm{~mol} / \mathrm{L}, \mathrm{pH}=8.3 ; 6\right)$ after contact with untreated $\mathrm{HSC}$ silt/clay using initially $\mathrm{Ca}^{2+}$-free solution, $[\mathrm{U}(\mathrm{VI})]=9.2 \times 10^{-7} \mathrm{~mol} / \mathrm{L}$, $\mathrm{pH}=7.3$; 7) after contact with untreated $\mathrm{HSC}$ silt/clay using initially $\mathrm{Ca}^{2+}$-free solution, $\left.[\mathrm{U}(\mathrm{VI})]=5.2 \times 10^{-7} \mathrm{~mol} / \mathrm{L}, \mathrm{pH}=8.5 ; 8\right)$ after contact with carbonate-free $\mathrm{HSC}$ silt/clay using calcite pre-saturated solution, $\left.[\mathrm{U}(\mathrm{VI})]=7.8 \times 10^{-7} \mathrm{~mol} / \mathrm{L}, \mathrm{pH}=7.3, ; 9\right)$ after contact with carbonate-free $\mathrm{HSC}$ silt/clay using initially $\mathrm{Ca}^{2+}$-free solution, $[\mathrm{U}(\mathrm{VI})]=2.5 \times 10^{-7}$ $\mathrm{mol} / \mathrm{L}, \mathrm{pH}=7.3$. The detailed solution compositions are given in Table 1 and $\mathrm{P}_{\mathrm{CO} 2}=$ $10^{-3.5} \mathrm{~atm}$ for all samples. For clarity, the spectra were normalized to the same maximum intensities and offset along the vertical axis. 
Figure 5. U(VI) sorption as a function of $\mathrm{pH}$ for the original HSC and two size fractions at $\mathrm{P}_{\mathrm{CO} 2}=10^{-3.5}$ atm: $\mathrm{O}=$ original HSC; $\diamond=$ untreated HSC silt/clay; $\mathbf{\square}=$ untreated HSC sand. Solid line (-) is the estimate of original HSC sorption as calculated from CA approach. (Initial $[\mathrm{U}(\mathrm{VI})]=1.2 \times 10^{-6} \mathrm{~mol} / \mathrm{L}$, solid/solution ratio $=100 \mathrm{~g} / \mathrm{L}, \mathrm{I}=0.05$ $\mathrm{mol} / \mathrm{L}\left(\mathrm{NaNO}_{3}\right)$, and temp. $=22.5{ }^{\circ} \mathrm{C}$.

a)

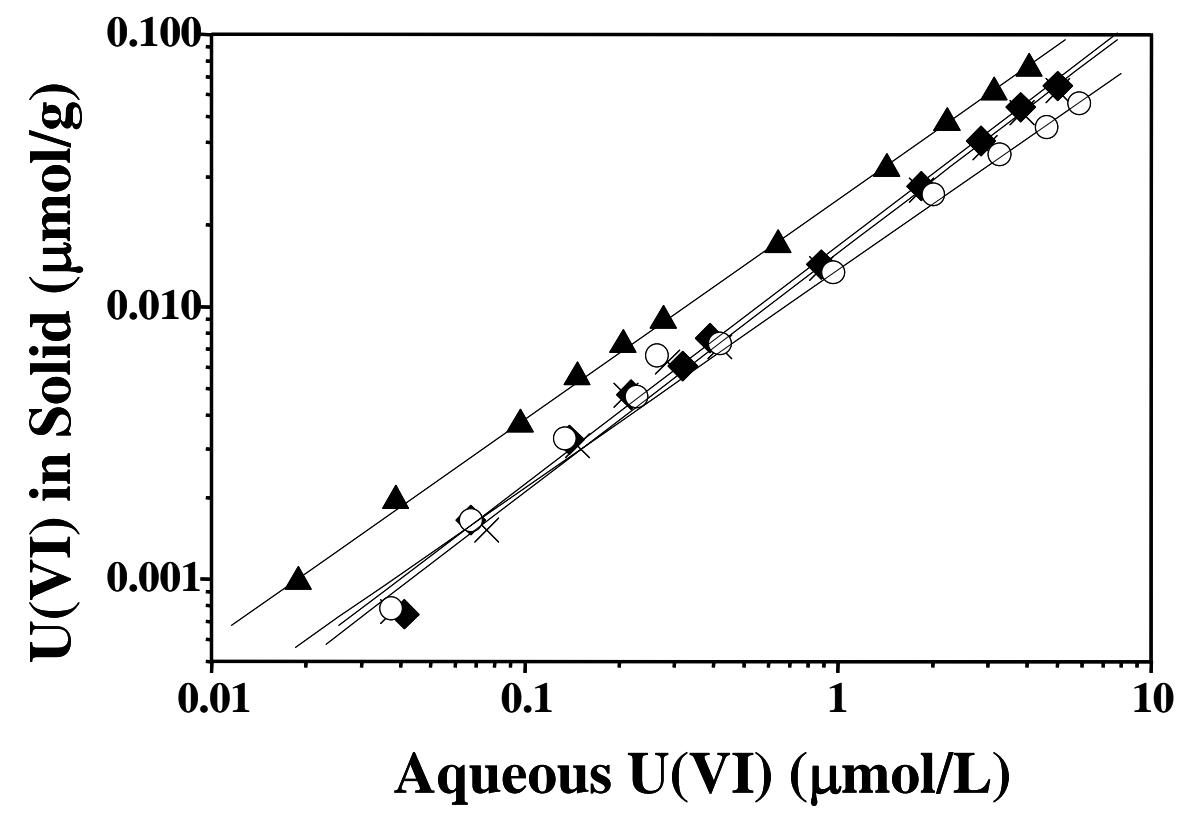

b)

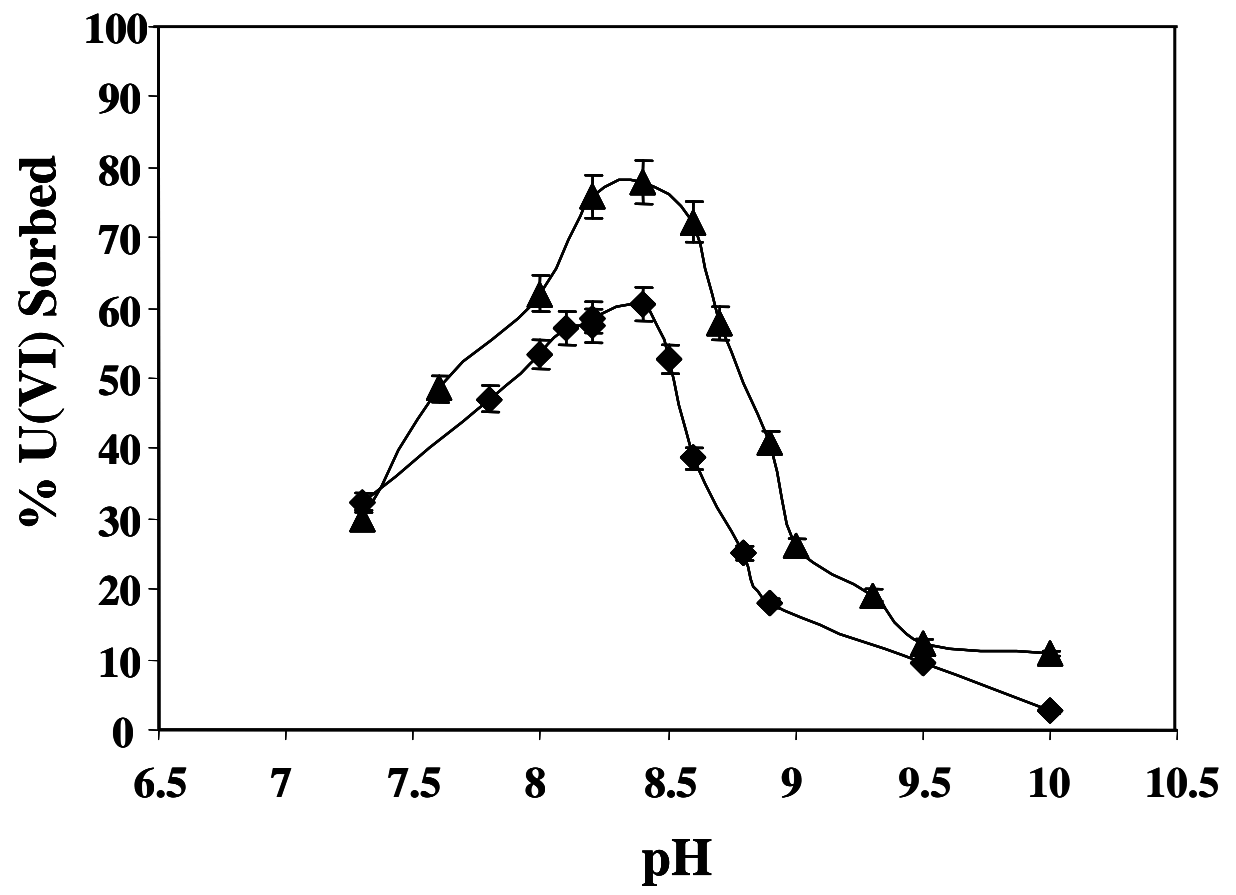

Figure 1 
Appendix I

a)

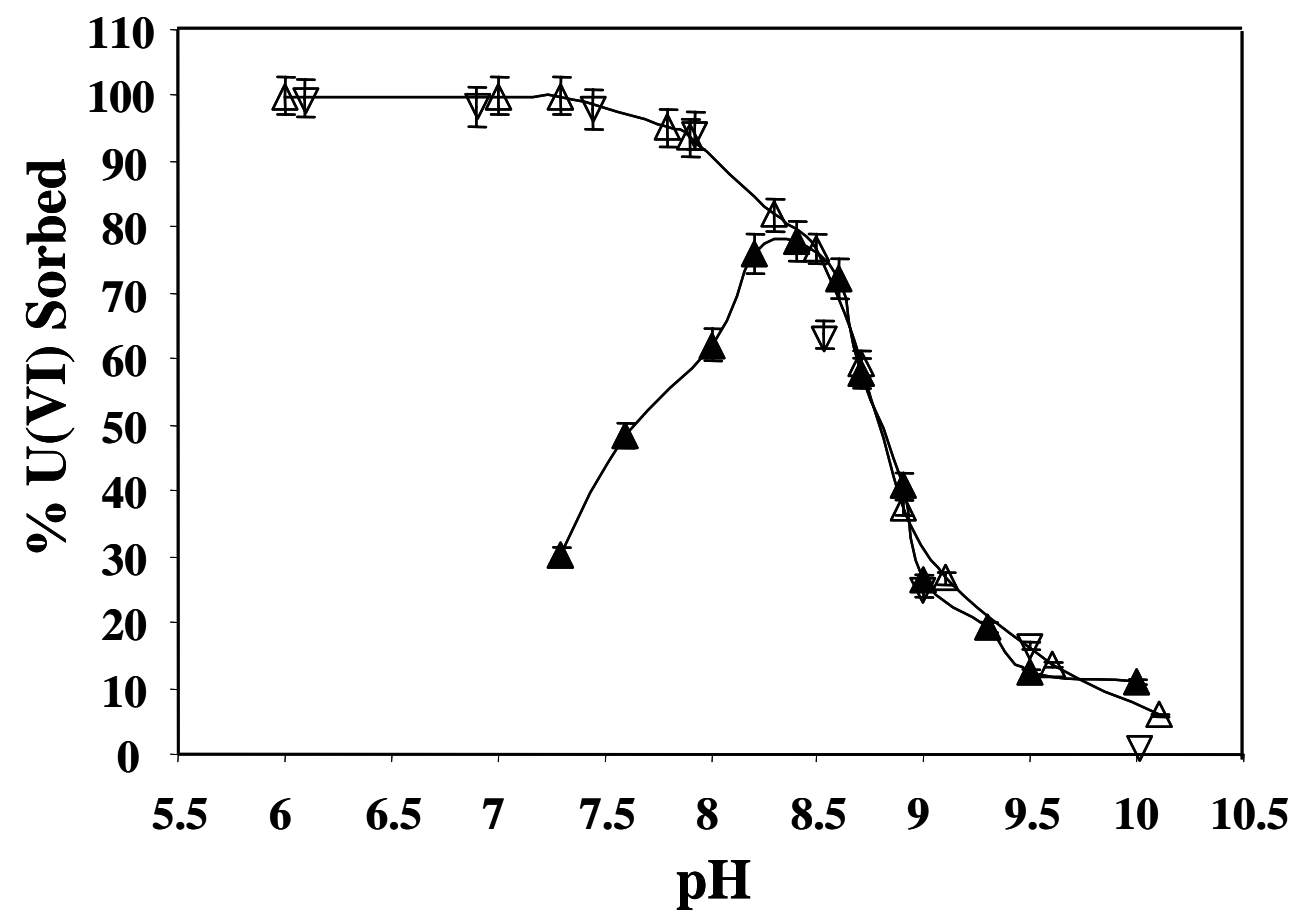

b)

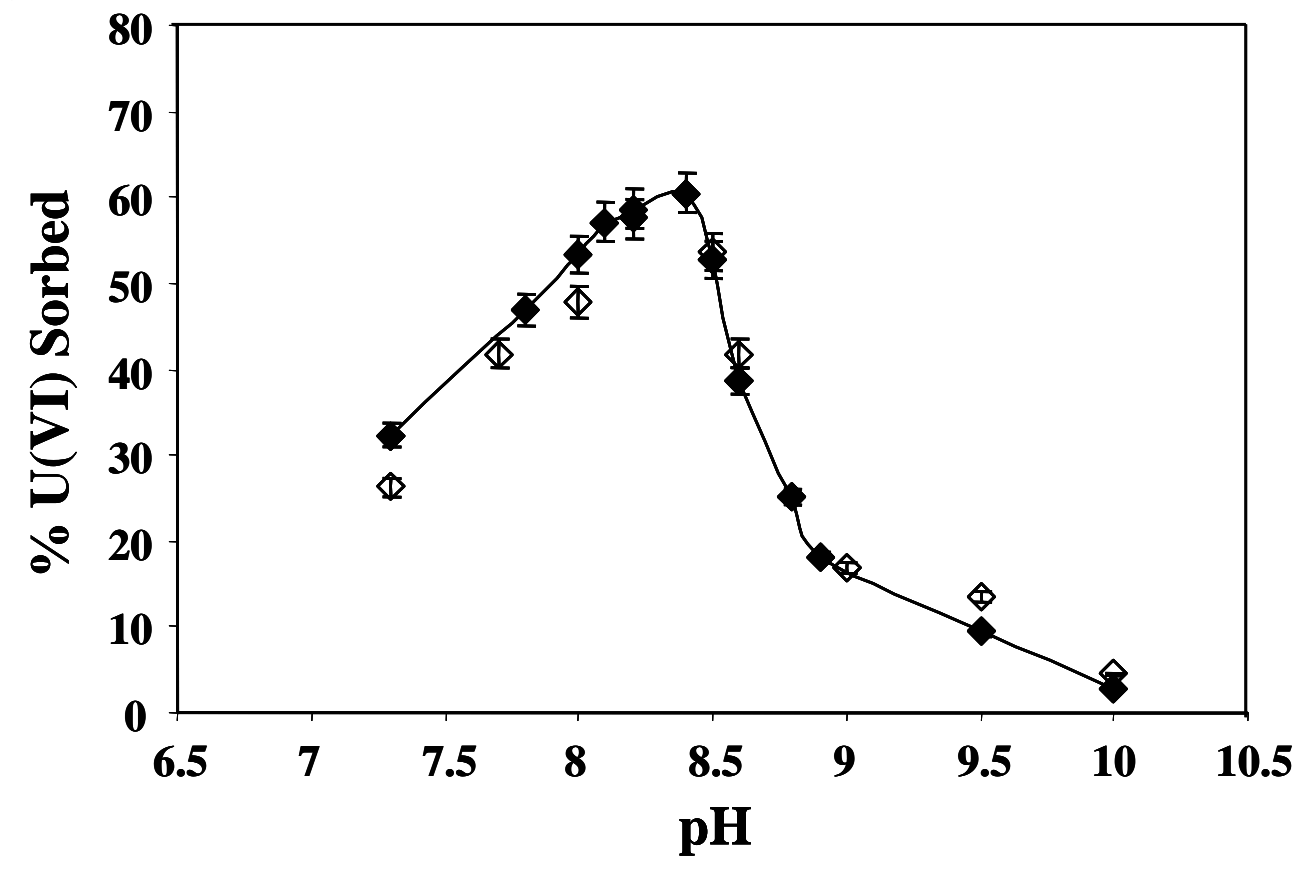

Figure 2 
Appendix I

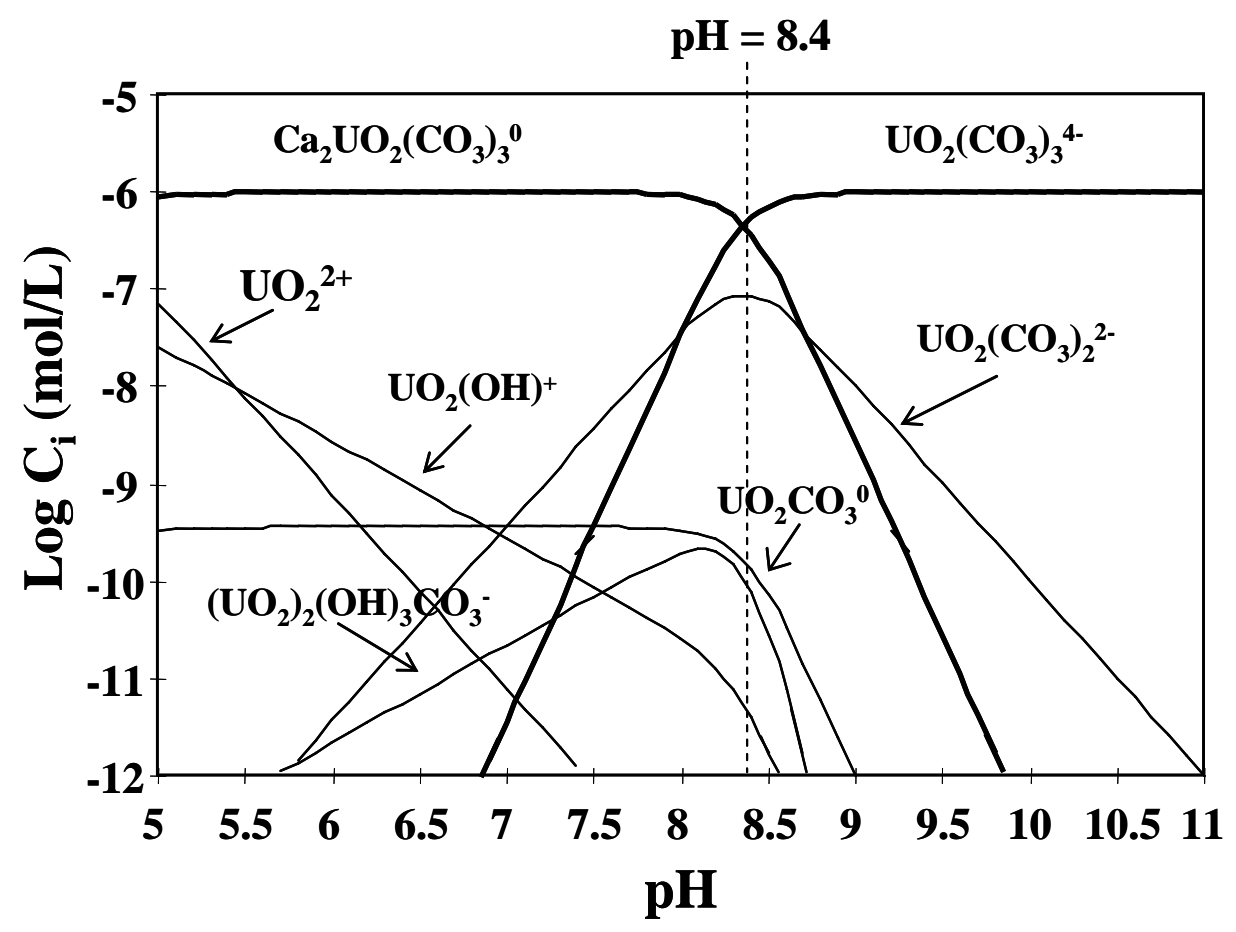

Figure 3

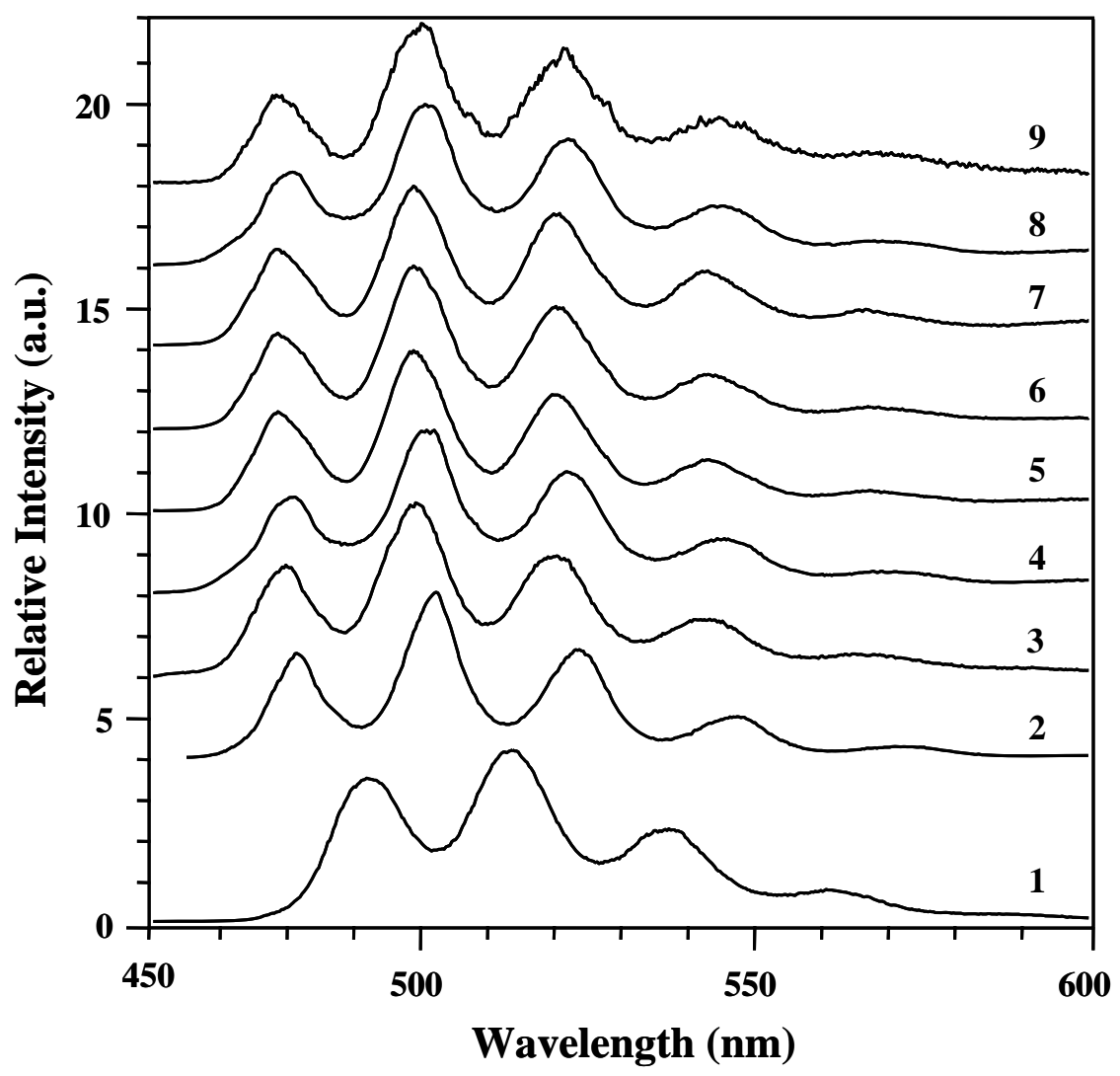

Figure 4 
Appendix I

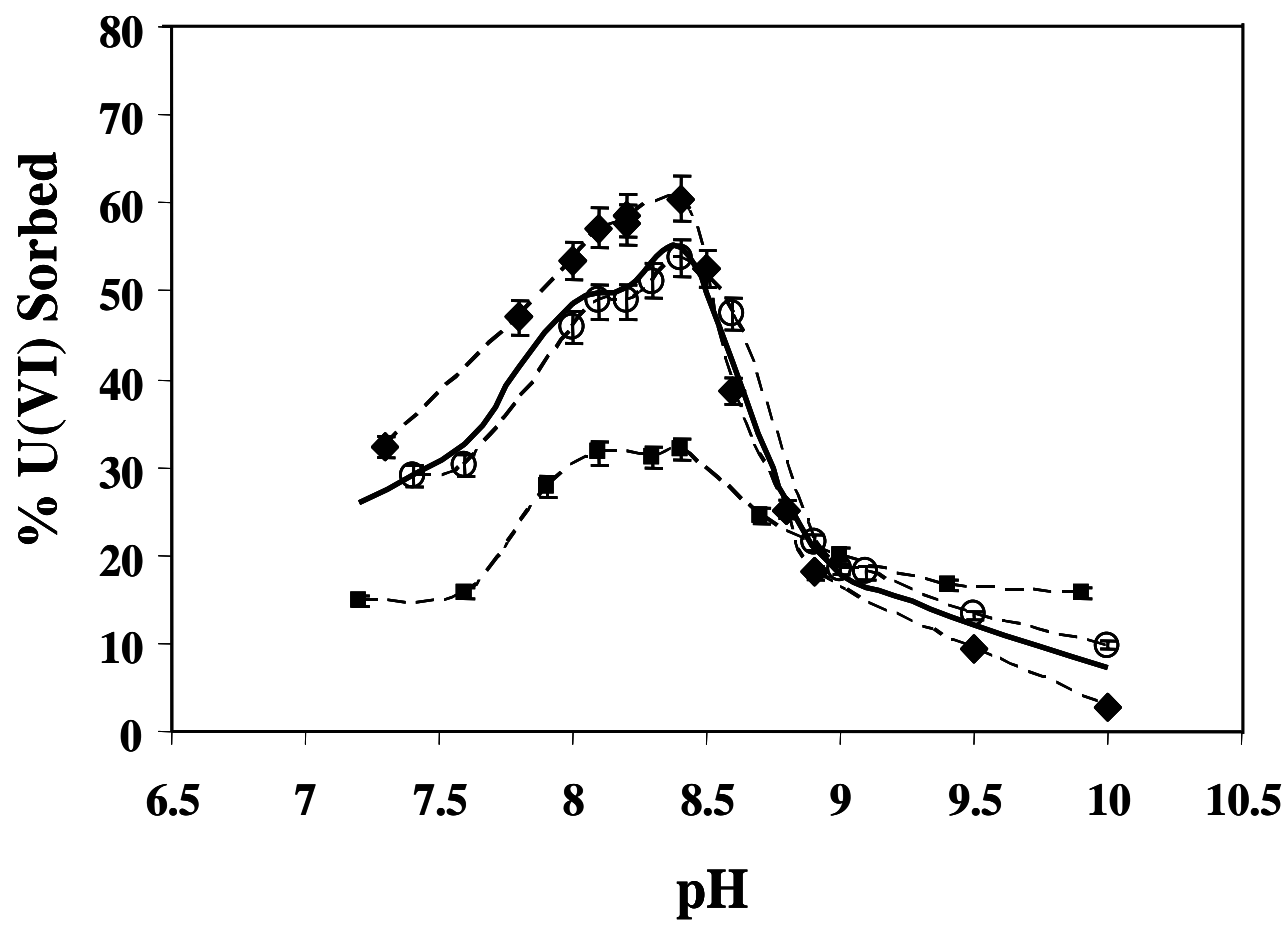

Figure 5 


\title{
Supporting Information for
}

\section{Influence of Calcite and Dissolved Calcium on U(VI) Sorption to a Hanford Subsurface Sediment}

\author{
Wenming Dong ${ }^{1,2}$, William P. Ball ${ }^{1 *}$, Chongxuan Liu ${ }^{3}$, \\ Zheming Wang ${ }^{3}$, Alan T. Stone ${ }^{1}$, Jing Bai ${ }^{1}$, and John Zachara ${ }^{3}$. \\ ${ }^{1}$ Department of Geography and Environmental Engineering, Johns Hopkins \\ University, 313 Ames Hall, 3400 North Charles Street, Baltimore, MD 21218 \\ 2 Currently with Environmental Sciences Division, Oak Ridge National \\ Laboratory, Oak Ridge, TN 37831-6038 \\ ${ }^{3}$ Pacific Northwest National Laboratory, Environmental Dynamics and \\ Simulations, Richland, WA 99352 \\ * Corresponding Author: Tel: (410) 516-5434; e-mail: bball@jhu.edu
}

Environmental Science and Technology

Number of pages (including this one): 11

Number of tables: 2

Number of figures: 3 


\section{Removal Carbonate Minerals from Sorbent Solids}

Approximately $150 \mathrm{~g}$ of the HSC silt/clay size fraction was split from the bulk sample and treated with a $1 \mathrm{~mol} / \mathrm{L}$ solution of sodium acetate $(\mathrm{NaAc})$ and acetic acid (HAc) at $\mathrm{pH} 5.0$ in order to extract carbonate minerals. The extraction procedure was identical to that used by Zachara et al.(1), except that an alternative dialysis membrane was used (SnakeSkin ${ }^{\mathrm{TM}}$ pleated dialysis tubing with 10,000 MW, Pierce Chemical Company, USA). The split of silt/clay size fraction was loaded into the dialysis tubing and combined with $100 \mathrm{~mL}$ of the NaAc-HAc solution. Dialysis tubes containing the silt/clay fraction were placed in $1.5 \mathrm{~L}$ of the NaAc-HAc solution for three days. Occasional mixing of the suspension in the tubing allowed complete extraction of carbonate minerals. After three days of extraction, the dialysate was discarded and replaced with $1.5 \mathrm{~L}$ of fresh $1 \mathrm{~mol} / \mathrm{L} \mathrm{NaAc}$. After two additional days the dialysate was discarded and replaced with deionized water. The dialysate was frequently replaced with deionized water over two days, and then the water was replaced with $1 \mathrm{mmol} / \mathrm{L} \mathrm{NaHCO}_{3}$ to neutralize the suspension $\mathrm{pH}$. The $1 \mathrm{mmol} / \mathrm{L} \mathrm{NaHCO}_{3}$ solution was then replaced with deionized water on a daily basis for three days. The suspension was dialyzed against deionized water until the electrical conductivity of the dialysate remained below $5 \mu \mathrm{S} / \mathrm{cm}$ after overnight equilibration. Finally, the extracted silt/clay fraction was air-dried and thoroughly mixed for use.

\section{Removal of Free Iron (Hydr)oxides from Sorbent Solids by the DCB Method}

Approximately $50 \mathrm{~g}$ of carbonate-removed HSC silt/clay size fraction was split from the sample obtained by the procedure described in Section I above. This material was extracted with dithionite-citrate-bicarbonate (DCB) (2) in order to remove small amounts of reducible $\mathrm{Fe}$ oxide. Following DCB treatment, the extracted isolate was treated three times with $3 \% \mathrm{H}_{2} \mathrm{O}_{2}$ to oxidize residual reductants, organic matter, and sorbed citrate (3). Such treatment also readily oxidizes any structural iron that may have been reduced to $\mathrm{Fe}(\mathrm{II})$ by the DCB treatment (4). The treated silt/clay was then dialyzed against deionized water and air-dried. Dithionite removes finely divided hematite, goethite, lepidocrocite, ferrihydrite, and noncrystalline iron oxides as well as organic-complexed Fe. The method extracts virtually no $\mathrm{Fe}$ (or $\mathrm{Al}$ ) from most crystalline silicate minerals, and thus provides an estimate of "free" (nonsilicate) Fe in soils. These samples from which the free iron oxides had been removed were subsequently used for comparative study of the influence of free iron oxides on U(VI) sorption.

\section{U(VI) Sorption Kinetics Study}

Prior to the conduct of U(VI) adsorption experiments, time studies of U(VI) uptake

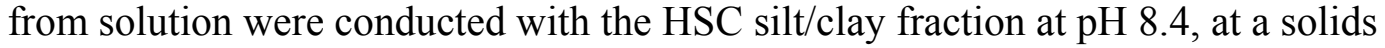
concentration of $100 \mathrm{~g} / \mathrm{L}$, and for times of equilibration varying between 5 minutes and 72 hours. Results indicated that the uptake of U(VI) from aqueous solution by the solids reached a stable plateau within 30 minutes. Results of the kinetics studies are shown graphically in Figure S-1. 


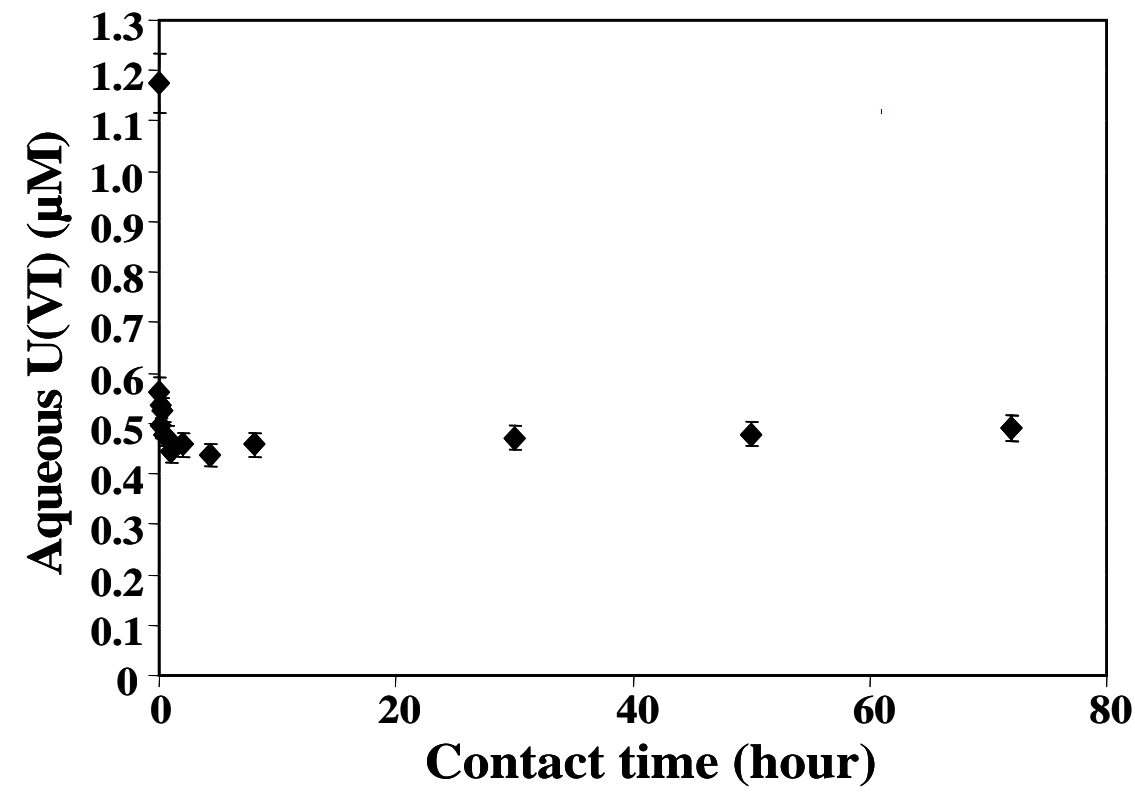

Figure S-1. Study of U(VI) sorption kinetics for Hanford silt/clay fraction in calcitesaturated solution with an initial U(VI) concentration of $1.2 \times 10^{-6} \mathrm{~mol} / \mathrm{L}$ at solid/solution ratio $=100 \mathrm{~g} / \mathrm{L}, \mathrm{I}=0.05 \mathrm{~mol} / \mathrm{L}\left(\mathrm{NaNO}_{3}\right), \mathrm{pH}=8.4 \pm 0.1, \mathrm{P}_{\mathrm{CO} 2}=10^{-3.5}$ atm and $22.5^{\circ} \mathrm{C}$.

\section{U(VI) Desorption Study.}

U(VI) desorption was performed to evaluate adsorption reversibility with the untreated HSC silt/clay fraction in initially calcite-saturated solutions at $\mathrm{pH}=8.3$. The solid sediments were collected via decanting the supernatants after centrifugation at the end of adsorption experiments and were mixed with a fresh U(VI)-free calcite-saturated solution $(\mathrm{pH}=8.3)$ at the same solid/liquid ratio as used during adsorption. After equilibration for three days, the suspensions were centrifuged ( $2100 \mathrm{~g}, 30$ minutes) and the supernatant U(VI) concentration was measured. The mass of adsorbed U(VI) after desorption was calculated as the difference between the total U(VI) in the system before desorption and the mass of U(VI) in aqueous solution after desorption. The sorption and desorption isotherms are showed in Figures S-2.

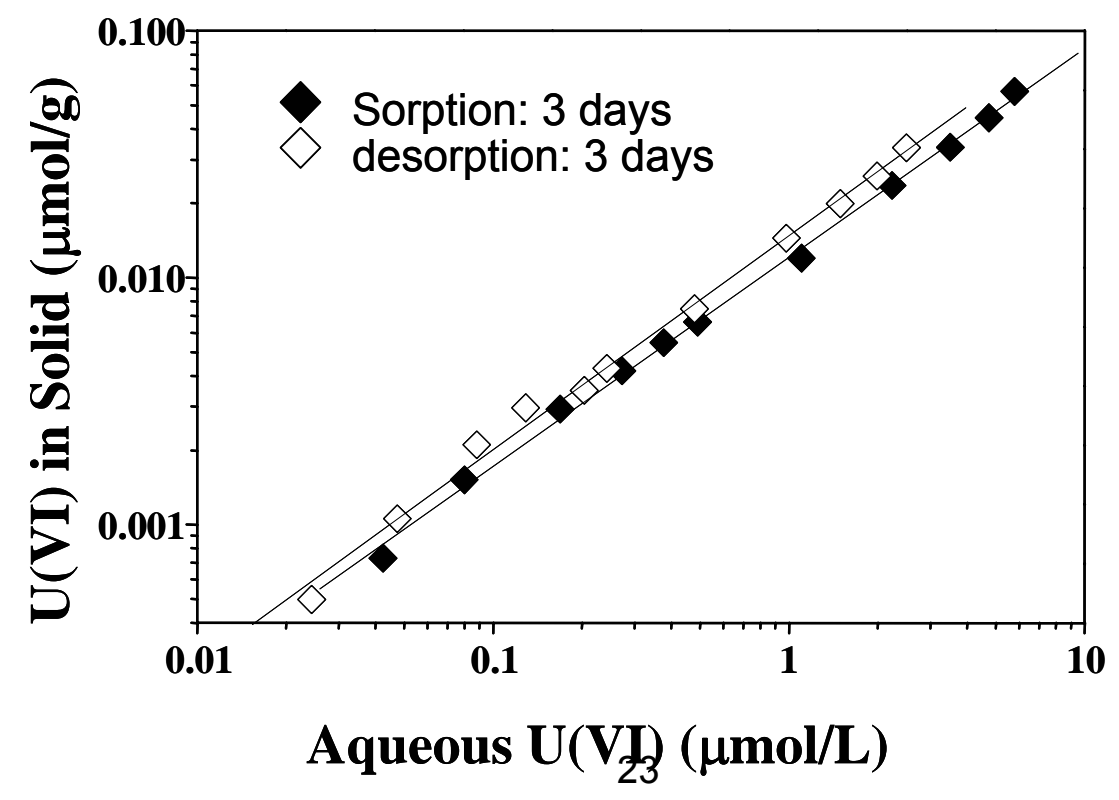


Figure S-2 U(VI) sorption $(\diamond)$ and desorption $(\diamond)$ isotherms from untreated HSC silt/clay in calcite pre-saturated solution at $\mathrm{pH}=8.3 \pm 0.1$ and $\mathrm{P}_{\mathrm{CO} 2}=10^{-3.5} \mathrm{~atm}$. (Initial [U(VI)] ranged from $1.0 \times 10^{-7}$ to $1.0 \times 10^{-5} \mathrm{~mol} / \mathrm{L}$, solid $/$ solution ratio $=100 \mathrm{~g} / \mathrm{L}, \mathrm{I}=0.05$ $\mathrm{mol} / \mathrm{L}\left(\mathrm{NaNO}_{3}\right)$, and temp. $\left.=22.5^{\circ} \mathrm{C}\right)$. Sorption and desorption times were both 3 days.

As shown in Figure S-2 and Table S-2, the desorption isotherm is slightly above that for adsorption. These results indicate that U(VI) adsorption onto the untreated HSC silt/clay fraction with initially calcite-saturated solutions was not fully reversible during 3 days of desorption following 3 days of adsorption. The isotherm difference between adsorption and desorption increased with increasing equilibrium aqueous U(VI) concentration (Figure S-2) with a relative difference of less than $25 \%$ in all samples. For example, calculated $\mathrm{K}_{\mathrm{d}}$ values at $\mathrm{pH} 8.3$ are roughly $12 \mathrm{~mL} / \mathrm{g}$ for sorption and $15 \mathrm{~mL} / \mathrm{g}$ for desorption, when evaluated at $\mathrm{C}_{\mathrm{e}}=1 \mu \mathrm{mol} / \mathrm{L}$ ). The results suggest that assumptions of rapidly reversible adsorption/desorption are reasonable estimates but perhaps not precisely accurate for this system. Based on the observed uptake kinetics (equilibrium within 30 minutes), kinetic limitations would seem to be more pronounced for desorption than for adsorption. Further work is needed to better evaluate such effects and to better understand the nature and causes of the differences observed in Figure S-2.

\section{Study of Background U(VI) Concentrations in Sediments and of U(VI) Loss to Reaction Vessels during U(VI) Adsorption Experiments}

Control experiments were used to determine the background aqueous concentrations of uranium that enters the electrolyte solution from the sediments at the experimental solids concentration of $100 \mathrm{~g} / \mathrm{L}$. The sediments had been pre-equilibrated with the electrolyte solutions at $\mathrm{pH}$ values in the range of those used in this work, using methods described in the main text (see section U(VI) Adsorption under Materials and Experimental Procedures). The concentrations of U(VI) in these pre-equilibrated samples were found to be on the order of 0.8 to $2 \times 10^{-9} \mathrm{~mol} / \mathrm{L}$, which is less than $2 \%$ of the minimum concentration used in all experiments $\left(\sim 10^{-7} \mathrm{~mol} / \mathrm{L}\right)$. Thus, background U(VI) should not affected the results of the experiments reported in this work.

Control experiments showed that uranium adsorption to the walls of the polyethylene tubes during the experiments was completely negligible for most experiments $\left(99.5 \% \pm 0.5 \%\right.$ recovery in samples with final concentrations at $10^{-6} \mathrm{~mol} / \mathrm{L}$ and above), although some very minor losses were observed at the lowest concentrations used for isotherm experiments $\left(99 \% \pm 1 \%\right.$ recovery in samples with final concentrations near $10^{-7}$ $\mathrm{mol} / \mathrm{L})$.

VI. Analysis of $\mathrm{Ca}^{2+}$ Concentrations in Sorption Supernatants

The calculated $\mathrm{Ca}^{2+}$ concentrations in sorption solutions saturated with respect to calcite is extremely sensitive to $\mathrm{pH}$. For example, equilibrium concentrations are estimated at 91 $\mathrm{mmol} / \mathrm{L}$ at $\mathrm{pH} 7.3,58 \mathrm{mmol} / \mathrm{L}$ at $\mathrm{pH} 7.4,3.6 \mathrm{mmol} / \mathrm{L}$ at $\mathrm{pH} 8.0$, and $0.36 \mathrm{mmol} / \mathrm{L}$ at $\mathrm{pH}$ 8.5. Actual concentrations of calcium were measured by ICP-OES in sorption supernatants for three individual samples of the untreated silt/clay fraction with initially calcium-free solutions, at $\mathrm{pH} 7.3,8.5$, and 9.5. For $\mathrm{pH} 7.3$ and 8.5 samples, the $\mathrm{Ca}^{2+}$ 
concentrations were 3.2 and $0.82 \mathrm{mmol} / \mathrm{L}$, respectively, which are at $3.5 \%$ and $228 \%$ of the values expected to be in equilibrium with calcite. At $\mathrm{pH} 9.5$, the calcium concentration was expected low, at $0.1 \mathrm{mmol} / \mathrm{L}$. In untreated silt/clay systems where solutions were pre-saturated with calcite, calcium concentrations were measured to be 8.7 $(\mathrm{pH}=7.3)$ and $0.77 \mathrm{mmol} / \mathrm{L}(\mathrm{pH}=8.3)$, which were 9.1 and $84 \%$, respectively of the calculated saturation concentrations. [NOTE: The low measured values of 3.5\% and 9.1\% of saturation are problematic with respect to our assumptions or methods. In particular, ICP analysis was conducted on supernatants that had been stored for 1 to 2 months prior to subsampling and acidification, and the solids tested with initially-calcium free water had been pre-rinsed with this same type of solution. Thus, the low values may reflect either a loss of calcium via calcium carbonate precipitation (due to $\mathrm{pH}$ change during sample storage and preparation) or may reflect genuine lack of saturation (owing to kinetic effects or because of calcite removal from sediments during pre-washing). The former cause is certainly more likely for the $9.1 \%$ value, which was obtained in a sample that saw only calcite pre-saturated solutions.] Finally, calcium concentrations were found to be negligible $(<0.02 \mathrm{mmol} / \mathrm{L})$ in the supernatants of samples prepared with treated (carbonate-free) silt/clay fraction and deionized water. Although separate analysis was conducted on sorption supernatants of the carbonate-removed silt/clay fraction with initially calcium-free solutions, these samples were compromised by errors in the laboratory and are therefore not reported.

According to the calcium concentrations measured in selected samples (untreated sediment suspensions with initially calcium-free electrolyte solution) $(3.2 \mathrm{mmol} / \mathrm{L}$ at $\mathrm{pH}$ 7.3 and $0.82 \mathrm{mmol} / \mathrm{L}$ at $\mathrm{pH} 8.5)$, speciation calculations suggest that $\mathrm{Ca}_{2} \mathrm{UO}_{2}\left(\mathrm{CO}_{3}\right)_{3}{ }^{0}$ (aq) would form in sufficient amount to represent $85 \%$ of the aqueous uranium at $\mathrm{pH} 7.3$ and $93 \%$ at $\mathrm{pH}$ 8.4. Similar calculations for the pre-saturated systems suggest that $98 \%$ of uranium as $\mathrm{Ca}_{2} \mathrm{UO}_{2}\left(\mathrm{CO}_{3}\right)_{3}{ }^{0}$ (aq) at $\mathrm{pH} 7.3$ and $93 \%$ at $\mathrm{pH} 8.4$. These calculations suggest that, for the measured values of $\left[\mathrm{Ca}^{2+}\right], \mathrm{Ca}_{2} \mathrm{UO}_{2}\left(\mathrm{CO}_{3}\right)_{3}{ }^{0}$ (aq) would still be the dominant species in solution and that the $\left[\mathrm{Ca}^{2+}\right]$ is therefore the likely cause for low adsorption at $\mathrm{pH}$ below $8.4 \pm 0.1$, as seen in Figure $2 \mathrm{~b}$.

\section{Investigation of Soil-Solution Separation Methods on U(VI) Equilibrium Concentration Measurement}

For the batch adsorption/desorption experiments, three soil-solution separation methods were studied to test for possible differences in efficiency of removal of U(VI)bearing colloidal particles from the solution phase, as shown in Table S-1. Batch adsorption experiments were conducted with untreated HSC silt/clay fraction using individual samples for each combination of separation technique and $\mathrm{pH}$, at final aqueous $\mathrm{U}(\mathrm{VI})$ concentrations in the range of 120 to $250 \mu \mathrm{g} / \mathrm{L}$ and at several $\mathrm{pH}$ values in the range of 7.8 to 9.4 .. Three methods of separation were tested: centrifugation at $3000 \mathrm{rpm}$ $(=2100 \mathrm{~g})$ for 30 minutes, centrifugation at $8000 \mathrm{rpm}(=5000 \mathrm{~g})$ for 30 minutes, and centrifugation at $2100 \mathrm{~g}$ for 30 minutes followed by filtration by $0.2 \mu \mathrm{m}$ filter membrane (first $1 \mathrm{~mL}$ filtrated discarded) were compared. Other procedures followed those are described in the Materials and Experimental Procedures section.

Results for $\mathrm{pH} 7.8$ were deemed not valid for comparison, owing to the fact that some small and unmeasured fluctuations in $\mathrm{pH}$ are believed to have affected results in this highly $\mathrm{pH}$ sensitive range. Results for the other four $\mathrm{pH}$ values studied are shown in 
Table S-1. In this table, concentrations are expressed as relative values assuming the concentration obtained by centrifugation at $2100 \mathrm{~g}$ for 30 minutes were 1.00 . At $99 \%$ confidence level, t-test for pairwise observations proved no significant differences of the relative concentrations from 1.00 , for all the three methods. This suggests that centrifugation at $2100 \mathrm{~g}$ for 30 minutes without filtration provides sufficiently complete separation of the solid and liquid phases. This procedure was used for all of the batch experiments in the reported study.

\begin{tabular}{|c|c|c|c|}
\hline \multirow{2}{*}{$\begin{array}{c}\text { Equilibrium } \\
\text { pH }\end{array}$} & \multicolumn{3}{|c|}{ Relative equilibrium U(VI) concentration $(\mu \mathrm{g} / \mathrm{L})$} \\
\hline & \begin{tabular}{|c|}
$2100 \mathrm{~g}$ for 30 \\
minutes
\end{tabular} & $\begin{array}{c}5000 \mathrm{~g} \text { for } 30 \\
\text { minutes }\end{array}$ & $\begin{array}{l}2100 \mathrm{~g} \text { for } 30 \text { minutes, then } \\
\text { filtered by } 0.2 \mu \mathrm{m} \text { membrane }\end{array}$ \\
\hline 8.1 & 1.00 & $1.03 \pm 0.03$ & $1.14 \pm 0.04$ \\
\hline 8.2 & 1.00 & $0.98 \pm 0.03$ & $1.02 \pm 0.03$ \\
\hline 8.7 & 1.00 & $0.97 \pm 0.03$ & $0.98 \pm 0.03$ \\
\hline 9.4 & 1.00 & $1.03 \pm 0.03$ & $1.01 \pm 0.03$ \\
\hline average & 1.00 & $1.00 \pm 0.03$ & $1.04 \pm 0.03$ \\
\hline
\end{tabular}

Table S-1. Ratio of U(VI) concentrations in supernatants relative to U(VI) concentration centrifuged at $2100 \mathrm{~g}$. U(VI) for single-sample batch adsorption experiments performed at $22.5^{\circ} \mathrm{C}$ on the untreated HSC silt/clay fraction. Initial U(VI) concentration $=1.2 \times 10^{-6}$ $\mathrm{mol} / \mathrm{L}(286.2 \mu \mathrm{g} / \mathrm{L})$, solid/solution ratio $=100 \mathrm{~g} / \mathrm{L}, \mathrm{I}=0.05 \mathrm{~mol} / \mathrm{L}\left(\mathrm{NaNO}_{3}\right)$, and $\mathrm{P}_{\mathrm{CO} 2}=$ $10^{-3.5} \mathrm{~atm}$. Standard deviations used for the single-sample measurements at each condition were those reported by the KPA instrument.

\section{LIFS Analysis}

Laser-induced fluorescence spectra (LIFS) were obtained using standard techniques (5). For this study, LIFS spectra of aqueous U(VI) species before and after U(VI) adsorption in calcite-saturated or calcium-free solutions were recorded from 450 to 600 $\mathrm{nm}$ at near liquid helium temperature $(\mathrm{LHeT}=6 \pm 1 \mathrm{~K})$ using a Cryo Industries RC-152 cryogenic workstation in which the sample cell, a $2 \mathrm{~mm} \times 4 \mathrm{~mm} \times 25 \mathrm{~mm}$ fused silica cuvette containing $\sim 0.1 \mathrm{~mL}$ solution and capped with a silicone stopper, was directly exposed to the vapor flow of liquid helium. The laser-induced time-resolved fluorescence spectrometer consists of a Spectra Physics Nd:YAG laser pumped MOPO-730 nanosecond pulsed laser running at $20 \mathrm{~Hz}$ at $415 \mathrm{~nm}$ and a thermoelectrically cooled Roper Scientific PIMAX time-gated intensified CCD camera (1024 x 256 pixels) that was attached to the exit port of an Acton SpectroPro 300i double monochromator spectrograph. Fluorescence emission was collected at right angle in respect to the excitation beam. Long-pass dichroic optical filters were placed in front of the input slit of the spectrograph to reject scattered laser light. The data acquisition was automated by the WinSpec ${ }^{\mathrm{TM}}$ data acquisition software. Fluorescence lifetimes were recorded by diverting the emitted light into a CVI model CM110 monochromator and detected by a Hamamatsu R928 photomultiplier tube (PMT) fitted with Hamamatsu C1392-57 time-gating PMT socket. The fluorescence intensity signal from the PMT was amplified and recorded with 
a Tektronix TDS 754A digital oscilloscope. Both spectral and lifetime data were processed using the commercial software package IGOR ${ }^{\mathrm{TM}}$.

\section{Calculation of U(VI) Speciation in Calcium-Free Solution}

Aqueous U(VI) speciation in calcium-free suspensions were calculated using FITEQL 4.0 (6) with a database assembled by the authors from the literature (7). Results are shown in Figure S-3.

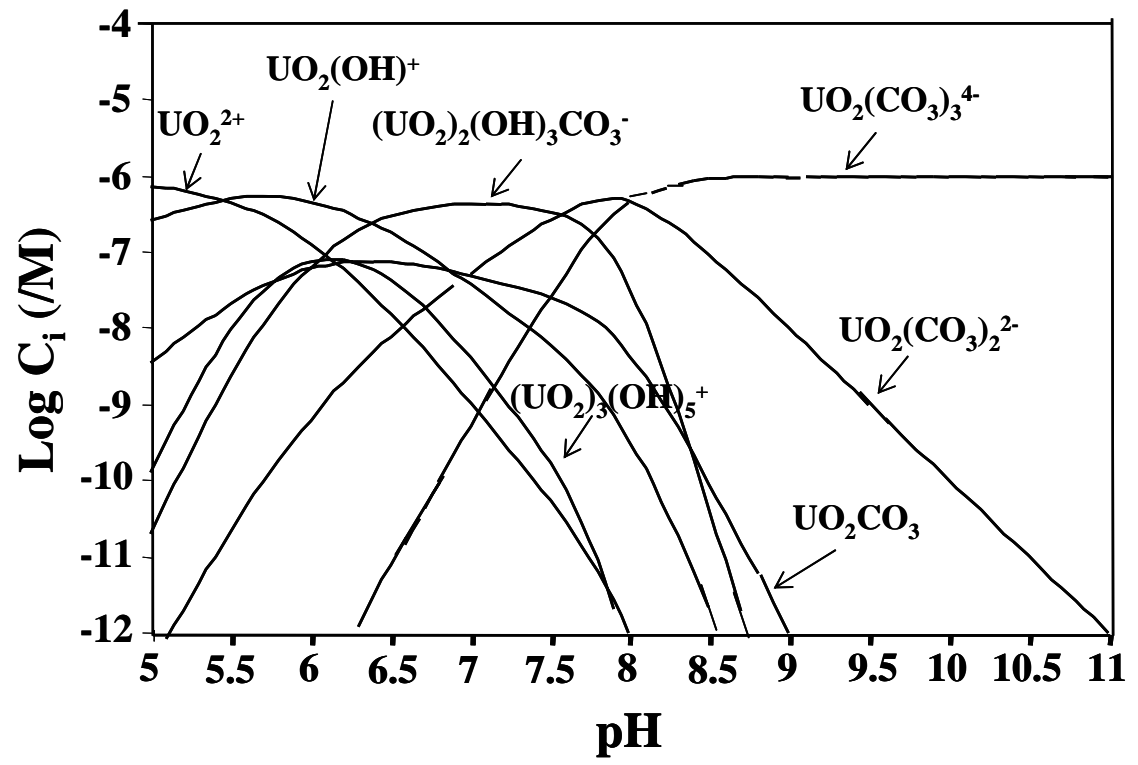

Figure S-3. U(VI) speciation in calcium-free solution with a U(VI) concentration of $1.0 \times 10^{-6} \mathrm{~mol} / \mathrm{L}$ under $\mathrm{I}=0.05 \mathrm{~mol} / \mathrm{L}, \mathrm{P}_{\mathrm{CO} 2}=10^{-3.5}$ atm and $22.5^{\circ} \mathrm{C}$. The complexation constants of all U(VI) species are from Grenthe et al.(7). 


\section{Freundlich Parameters of U(VI) Sorption Isotherms}

Parameters of Freundlich isotherm fits to the data shown in Figure 1a and Figure 5 of the manuscript are provided in Table S-2 on the following page.

\begin{tabular}{|l|c|c|c|c|}
\hline & \multirow{2}{*}{$\mathbf{p H}$} & \multicolumn{3}{|c|}{ Freundlich Model: $\mathbf{S}=\mathbf{K}_{\mathbf{f}} \mathbf{C}^{\mathbf{n}}$} \\
\cline { 3 - 5 } & $\begin{array}{c}\mathbf{K}_{\mathbf{f}} \\
(\mu \mathrm{mol} / \mathrm{kg}) /(\mu \mathrm{mol} / \mathrm{L})^{\mathrm{n}}\end{array}$ & $\mathbf{n}$ & $\mathbf{R}^{\mathbf{2}}$ \\
\hline $\begin{array}{l}\text { carbonate- free } \\
\text { HSC silt/clay (Fig. 1a) }\end{array}$ & $8.4 \pm 0.1$ & $24 \pm 1$ & $0.80 \pm 0.01$ & 0.9997 \\
\hline calcite (Fig. 1a) & $8.4 \pm 0.1$ & $16 \pm 1$ & $0.88 \pm 0.02$ & 0.9976 \\
\hline original HSC (Fig. 1a) & $8.4 \pm 0.1$ & $14 \pm 1$ & $0.80 \pm 0.03$ & 0.9950 \\
\hline $\begin{array}{l}\text { untreated } \\
\text { HSC silt/clay (Fig. 1a) }\end{array}$ & $8.4 \pm 0.1$ & $16 \pm 1$ & $0.88 \pm 0.02$ & 0.9972 \\
\hline $\begin{array}{l}\text { untreated HSC silt/clay, } \\
\text { sorption (Fig. 5) }\end{array}$ & $8.3 \pm 0.1$ & $12 \pm 1$ & $0.85 \pm 0.01$ & 0.9989 \\
\hline $\begin{array}{l}\text { untreated HSC silt/clay, } \\
\text { desorption (Fig. 5) }\end{array}$ & $8.3 \pm 0.1$ & $15 \pm 1$ & $0.87 \pm 0.02$ & 0.9975 \\
\hline
\end{tabular}

Table S-2. U(VI) sorption isotherms on four materials (and a desorption isotherm on untreated HSC silt/clay) from calcite-pre-saturated solutions at $\mathrm{P}_{\mathrm{CO} 2}=10^{-3.5}$ atm (Initial [U(VI)] ranged from $1.0 \times 10^{-7}$ to $1.0 \times 10^{-5} \mathrm{~mol} / \mathrm{L}$, solid $/$ solution ratio $=100 \mathrm{~g} / \mathrm{L}, \mathrm{I}=0.05$ $\mathrm{mol} / \mathrm{L}\left(\mathrm{NaNO}_{3}\right)$, and temp. $=22.5{ }^{\circ} \mathrm{C}$.) Data correspond to isotherm models shown as solid lines in Figures 1a and 5 of the primary manuscript.

\section{References}

(1) Zachara, J. M.; Smith, S. C.; Liu, C.; McKinley, J. P.; Serne, R. J.; Gassman, P. L. Sorption of $\mathrm{Cs}^{+}$to micaceous subsurface sediments from the Hanford site, USA. Geochim. Cosmochim. Acta 2002, 66, 193-211.

(2) Mehra, O. P.; Jackson, M. L. Iron oxides removal from soils and clays by a dithionite-citrate system buffered with sodium bicarbonate.7th Natl. Conf. Clays and Clay Minerals, 1960, pp 317-327.

(3) Turner, G. D.; Zachara, J. M.; McKinley, J. P.; Smith, S. C. Surface-charge properties and $\mathrm{UO}_{2}{ }^{2+}$ adsorption of a subsurface smectite. Geochim. Cosmochim. Acta 1996, 60, 3399-3414.

(4) Komadel, P.; Lear, P. R.; Stucki, J. W. Reduction and reoxidation of nontronite: Extent of reduction and reaction rates. Clays and Clay Minerals 1990, 38, 203-208.

(5) Rabinowitch, E.; Belford, R. L. Spectroscopy and Photochemistry of Uranyl Compounds; Pergamon Press: McMillan, New York, 1964.

(6) Herbelin, A.; Westall, J. A Computer Program for Chemical Equilibrium Constants from Experimental Data; Oregon State University, 1999.

(7) Grenthe, I.; Fuger, J.; Konings, R. J. M.; Lemire, R. J.; Muller, A. B.; Nguyen-Trung, C.; Wanner, H. Chemical Thermodynamics Vol1: Chemical Thermodynamics of Uranium; North-Holland Elsevier Science: New York, 1992. 
Appendix II

\section{Appendix II}

Contents of Appendix II:

- Protocol A. Extraction of Carbonate Minerals and Free Iron Oxides

- Protocol B. Determination of the Mass Content of Carbonate Minerals and Free Iron Oxides

- Protocol C. Batch Sorption and Desorption Experiments at pH 9.4 $( \pm 0.1)$ and pH $8.0( \pm 0.1)$ 


\section{Protocol A. Extraction of Carbonate Minerals and Free Iron Oxides}

Carbonate Minearls. Approximately $150 \mathrm{~g}$ of silt/clay size fraction was splitted and treated with $1 \mathrm{M}$ sodium acetate $(\mathrm{NaOAc})$ with acetic acid at $\mathrm{pH} 5.0$ to extract carbonate minerals. The extraction procedure was identical to those used by Zachara et al. \{Zachara, $2002 \# 10$ \}, except that the SnakeSkin ${ }^{\mathrm{TM}}$ pleated dialysis tubing with 10,000 MW (Pierce Chemical Company, USA) was used in this study. The split of silt/clay size fraction was loaded into SnakeSkin ${ }^{\mathrm{TM}}$ pleated dialysis tubing and combined with $100 \mathrm{ml}$ of NaOAc solution. Dialysis tubes containing the silt/clay fraction were placed in $1.5 \mathrm{~L}$ of NaOAc solution for three days. Occasional mixing of the suspension in the tubing allowed complete extraction of carbonate minerals. After three days of extraction, the dialysate was discarded and replaced with $1.5 \mathrm{~L}$ of fresh $1 \mathrm{M} \mathrm{NaOAc}$. After two additional days the dialysate was discarded and replaced with deionized water. The dialysate was frequently replaced with deionized water over two days, and then the water was replaced with $1 \mathrm{mM} \mathrm{NaHCO} 3$ to neutralize the suspension $\mathrm{pH}$. Then $1 \mathrm{mM} \mathrm{NaHCO}_{3}$ was replaced daily for three days, and was replaced with deionized water. The suspension was dialyzed against deionized water until the electrical conductivity of the dialysate remained below $5 \mu \mathrm{S} / \mathrm{cm}$ after overnight equilibration. The extracted silt/clay fraction was air-dried and thoroughly mixed for use.

Free Iron Oxides. Approximately $50 \mathrm{~g}$ of acetate-treated silt/clay size fraction was split and extracted with dithionite-citrate-bicarbonate (DCB) \{Mehra, 1960 \#37\} to remove small amounts of reducible Fe oxide. The extracted isolate was then treated three times with $3 \% \mathrm{H}_{2} \mathrm{O}_{2}$ to oxidized residual reductants, organic matter, and sorbed citrate \{Turner, 1996 \#30 . Such treatment readily oxidizes any structural Fe(II) that may have been reduced by DCB treatment $\{$ Komadel, $1990 \# 38\}$. The treated silt/clay was then dialyzed against deionized water and air-dried. Dithionite removes finely divided hematite, goethite, lepidocrocite, ferrihydrite, and noncrystalline iron oxides as well as organiccomplexed Fe. The method extracts virtually no Fe (or Al) from most crystalline silicate minerals, and thus provides an estimate of "free" (nonsilicate) Fe in soils. The free iron oxides removed sample was used for comparative study of the influence of free iron oxides for U(VI) sorption. 


\section{Protocol B: Determination of the Mass Content of Carbonate Minerals and Free Iron Oxides}

Carbonates: Total carbonate content in the solid samples were measured by the Coulometric method. About 0.4 - $0.6 \mathrm{~g}$ solid samples were added in a ceramic ladle and were placed in a combustion furnace (CM5030, UIC Coulometrics Inc., IL) in which the carbonate minerals were combusted and catalyzed by barium chromate and reduced silver to $\mathrm{CO}_{2}$ at $950^{\circ} \mathrm{C}$. The $\mathrm{CO}_{2}$ was measured in a $\mathrm{CO}_{2}$ Coulometer (Model 5012, UIC Coulometrics Inc., IL), where it reacted with ethanolamine solution to form a strong, titratable acid, which in turn caused the ethanolamine solution's colorimetric $\mathrm{pH}$ indicator to fade from blue to clear. The acid was titrated by a neutralizing base generated electrochemically, ensuring that the color would change from clear to the original level of blue, monitored by a built-in photometer in the $\mathrm{CO}_{2}$ Coulometer. The electric current generated in the process was used to calculate the amount of $\mathrm{CO}_{2}$ and, subsequently, the total carbon (TC) content in the solid sample was obtained.

To measure total organic carbon (TOC) content, about $0.6 \mathrm{~g}$ soil sample was placed in the ceramic ladle and was treated by adding about $2 \mathrm{~mL} 1 \mathrm{~mol} / \mathrm{L} \mathrm{HCl}$ to remove the inorganic carbonate minerals. The samples were left overnight for $>12$ hours, then were heated dry at $80{ }^{\circ} \mathrm{C}$ for $>8$ hours. Then the total carbon in the treated samples was measured by the Coulometric method to represent the total organic carbon content. The total inorganic carbon (TIC) content was calculated as the difference of TC and TOC $(\mathrm{TIC}=\mathrm{TC}-\mathrm{TOC})$. The TIC was assumed to be contributed by calcite only so that the calcite content was calculated accordingly.

Free iron oxides: The free iron oxides were measured using citrate-dithionite method $\{$ Carter, $1993 \# 35\} .1 .00 \mathrm{~g}$ of sediment, $50 \mathrm{ml}$ of $0.68 \mathrm{~mol} / \mathrm{L}$ sodium citrate solution, and $0.8 \mathrm{~g}$ dithionite were respectively added into a $50 \mathrm{ml}$ plastic centrifuge tube, shaken in a Glas-Col Rotator (Terre Haute, IN, USA) overnight, centrifuged at $3000 \mathrm{rpm}$ for 30 minutes. $5 \mathrm{ml}$ of the supernatant was taken into a $50 \mathrm{ml}$ serum bottle, $5 \mathrm{ml} \mathrm{30 \%}$ $\mathrm{H}_{2} \mathrm{O}_{2}$ and $5 \mathrm{~mL} \mathrm{70 \%} \mathrm{HNO}_{3}$ were added and heated at a hot plate to approach dry. $20 \mathrm{ml}$ of $5 \% \mathrm{HCl}$ by mass was added to dissolve the residual overnight and filtered with $0.2 \mathrm{um}$ membrane. $10 \mathrm{~mL}$ of filtrate was used for Fe analysis by ICP-OES at PNNL). 


\section{Protocol C. Batch Sorption and Desorption Experiments at pH $9.4( \pm 0.1)$ and $\mathrm{pH} 8.0$ ( $\pm \mathbf{0 . 1})$}

$\mathrm{U}(\mathrm{VI})$ batch adsorption experiments were conducted in 5-mL or $10-\mathrm{mL}$ polyethylene centrifuge tubes at various desired solid/liquid ratios. Preliminary experiments with various solid/liquid ratios (10 to $500 \mathrm{~g} / \mathrm{L})$ at $\mathrm{pH} 8.4$ and $\mathrm{pH} 8.0$ indicated that U(VI) sorption increased with increasing solid/liquid ratio in a manner that was consistent with the soil-water distribution coefficient $\left(\mathrm{K}_{\mathrm{d}}\right)$ and independent of the solid/liquid ratio. A ratio of $100 \mathrm{~g} / \mathrm{L}$ was selected for $\mathrm{pH} 8.0$ sorption/desorption experiments based on a criterion of achieving a supernatant U(VI) concentration that was sufficient for measurement while still maintaining measurable amounts of uptake. Final uptake from solution was in the range of $20 \%$ to $80 \%$ for most experiments. For sorption/desorption experiments at $\mathrm{pH} 9.4$, various solid/solution ratios were tested. All subsequent equilibrium sorption experiments were conducted with 72 hours of equilibration for consistency with preliminary kinetics studies that had been conducted for that duration. Desorption experiments were conducted as long as 144 hours for $\mathrm{pH} 8.0$.

For all sorption experiments, the solid samples were equilibrated with U-free electrolyte solutions prior to addition of U(VI). The solid suspensions were continuously mixed by end-over-end rotation of sorption vessels at $45 \mathrm{rpm}$ for 3 days (Model 099A RD4512, Glas-Col Rotator Co., Terre Haute, IN) and centrifuged at $4000 \mathrm{~g}$ for 45 minutes, after which the supernatants were decanted and replaced with fresh calcitesaturated or $\mathrm{Ca}^{2+}$-free solution and the process repeated. After four such equilibration cycles, stable $\mathrm{pH}$ values were observed in all of the test suspensions. After the fourth decantation, the amount of remaining supernatant with the solids was gravimetrically determined and the samples were then spiked with an appropriate volume U(VI) stock solution as needed to achieve the desired initial [U(VI)]. The U(VI)-spiked tubes were then equilibrated for four days on the rotator shaker and kept in equilibrium with atmospheric $\mathrm{CO}_{2}$ by opening the tube caps frequently and replacing the headspace $(\sim 3$ to $5 \mathrm{~mL}$ ) with fresh air. After equilibration, the suspensions were centrifuged at $4000 \mathrm{~g}$ for 45 minutes and supernatants were measured for $\mathrm{pH}$ and aqueous U(VI) concentration. The adsorbed U(VI) was calculated as the difference between total added U(VI) and equilibrium aqueous U(VI). All experiments were conducted with duplicate samples. In addition, for experiments at $\mathrm{pH}$ 8.0, U(VI) desorption experiment with fresh U(VI)-free calcite-saturated stock solutions of the same $\mathrm{pH}$ at the end of sorption experiment was performed using 3-6 days of desorption time.

Control experiments at the same $\mathrm{pH}$ values were used to quantify background U(VI) concentration in electrolytes and soils, and U(VI) losses to tube walls. Both effects were found to be negligible. 